\title{
Evaluating the Effects of Exogenous Enzyme Supplementation on Broiler Growth
}

\author{
Victoria E. Ayres \\ West Virginia University, vep0003@mix.wvu.edu
}

Follow this and additional works at: https://researchrepository.wvu.edu/etd

Part of the Poultry or Avian Science Commons

\section{Recommended Citation}

Ayres, Victoria E., "Evaluating the Effects of Exogenous Enzyme Supplementation on Broiler Growth" (2019). Graduate Theses, Dissertations, and Problem Reports. 3878.

https://researchrepository.wvu.edu/etd/3878

This Thesis is protected by copyright and/or related rights. It has been brought to you by the The Research Repository @ WVU with permission from the rights-holder(s). You are free to use this Thesis in any way that is permitted by the copyright and related rights legislation that applies to your use. For other uses you must obtain permission from the rights-holder(s) directly, unless additional rights are indicated by a Creative Commons license in the record and/ or on the work itself. This Thesis has been accepted for inclusion in WVU Graduate Theses, Dissertations, and Problem Reports collection by an authorized administrator of The Research Repository @ WVU. For more information, please contact researchrepository@mail.wvu.edu. 
2019

Evaluating the Effects of Exogenous Enzyme Supplementation on Broiler Growth

Victoria E. Ayres

Follow this and additional works at: https://researchrepository.wvu.edu/etd

Part of the Poultry or Avian Science Commons 
Evaluating the Effects of Exogenous Enzyme Supplementation on Broiler Growth

\author{
Victoria E. Ayres
}

Thesis submitted to the Davis College of Agriculture, Natural Resources, and Design at West Virginia University

In partial fulfillment of the requirements for the degree of

Master of Science in Nutrition and Food Science

Joseph S. Moritz, Ph.D., Chair

Robert L. Taylor Jr., Ph.D.

Janet Tou, Ph.D.

Division of Animal and Nutritional Sciences

Morgantown, West Virginia

2019

Keywords: Broiler, NSPase, Phytase, Protease

Copyright 2019 V. E. Ayres 


\begin{abstract}
Experiments were conducted to investigate the effects of exogenous enzymes in poultry diets. In Chapter 4, a study was conducted to determine the effects of a corn-expressed recombinant carbohydrase (AC1) on broiler performance and digesta viscosity in high non-starch polysaccharide (NSP) diets through 21 days of age. One day-old Hubbard $\times$ Cobb 500 chicks were assigned to 6 dietary treatments. Each treatment consisted of 12 replicate pens of 10 birds. The positive control diet (PC) was a corn and soybean meal formulation. The negative control diet (NC) included $10 \%$ wheat and 10\% corn distiller's dried grains with solubles (DDGS). The NC contained $100 \mathrm{kcal} / \mathrm{kg}$ less ME than the PC. Increasing inclusions of AC1 were applied to the NC to contain 50, 100, 200, and $400 \mathrm{U} \beta$-glucanase ( $\boldsymbol{\beta}$-Glu-U) per kg of feed. Preliminary experiments demonstrated AC1 homogeneity and stability post pelleting. Live weight gain (LWG) was the highest for PC fed birds from 1 to $14 \mathrm{~d}$; however, birds fed NC with $400 \beta$-Glu-U/kg also had similar LWG as the PC. Feed conversion ratio (FCR) from d 1 to 21 was lowest for PC fed birds; however, birds fed NC with $400 \beta-$ Glu-U/kg also had similar FCR as PC. Birds fed NC had lower LWG and higher viscosity than birds fed PC on day 14 , but not on day 21 . However, birds supplemented with 200 or $400 \beta-$ Glu-U/kg had similar 14 d digesta viscosity as birds fed PC. These data indicate that NSP ingredients may have a greater impact on digesta viscosity early in broiler growth and that $\mathrm{AC} 1$ at 200 and $400 \beta-\mathrm{Glu}-\mathrm{U} / \mathrm{kg}$ produced similar results to PC.

A second study was then conducted (Chapter 2) to further investigate the effects of AC1 on dietary and intestinal viscosity and broiler performance when included in a high NSP diet. Nine hundred sixty, Hubbard x Ross 708, day-old, male broiler chicks were fed one of eight dietary treatments for 21d. Diets included a corn-soybean meal based diet (PC_1) and a diet of similar essential nutrient density, but with a $10 \%$ inclusion of both wheat and DDGS (PC_2) and a negative control (NC) with similar ingredients as PC_2, but with ME reduced by $125 \mathrm{kcal} / \mathrm{kg}$.
\end{abstract}


Additional treatments had varying levels of AC1, supplying 50, 100, 200, 400, or $600 \mathrm{U} \beta$ Glucanase ( $\boldsymbol{\beta}-\mathbf{G l u}-\mathbf{U})$ per kg of feed, mixed into the NC diet. Dietary and digesta (d14) viscosity and weekly bird performance were measured. The inclusion of $\mathrm{AC} 1$ at $50-400 \beta-\mathrm{Glu}-\mathrm{U} / \mathrm{kg}$ reduced FCR equivalent to PC_1. The results also showed that intestinal viscosity was correlated to d1-21 FCR and inversely correlated to d1-21 LWG. This study demonstrates that AC1 can reduce intestinal viscosity and improve early FCR in birds fed high viscosity diets and that an in vitro viscosity assay may be used to predict in vivo response.

In Chapter 3, a study was conducted to determine digestible amino acid concentrations and broiler performance of diets that vary in amino acid concentration and enzyme inclusion. Treatments included a PC (100\% amino acid recommendations), NC (85\% amino acid recommendations), and six additional diets containing commercially available enzyme supplements (Single Dose Phytase, Super Dose Phytase, Single Dose NSPase, Super Dose Phytase + Single Dose NSPase, Protease 1, and Protease 2) added to the NC based on manufacturers' recommendations. Diets were conditioned at $70^{\circ} \mathrm{C}$ and fed as crumbles to Hubbard x Ross 708 broiler chicks for $22 \mathrm{~d}$. Feeding NC with the inclusion of phytase, independent of dose or combination with the NSPase, and Protease 1 produced d22 feed conversion ratio similar to the PC. When feeding NC with the single dose NSPase, Protease 1, or Protease 2 d22 LWG was not comparable to the PC. These data suggest that the addition of phytase to an amino acid deficient diet can improve broiler performance. 


\section{Acknowledgements}

This accomplishment could not have been achieved without the help of several people along the way. I would first like to thank my advisor, Dr. Joseph Moritz. I have been blessed with the opportunity to further my education with his continuous support and guidance. I would also like to thank my committee members, Dr. Robert Taylor and Dr. Janet Tou for their support throughout my research and graduate courses. Dr. Taylor, I have enjoyed learning about avian genetics and working with you throughout your project. Dr. Tou, thank you for your encouragement and kind words of advice. I would like to thank the West Virginia University Animal Science Farm staff and faculty, as well, for their assistance with our ongoing studies. I would also like to extend my gratitude to my fellow lab mates, as our area of study is quite labor intensive: Timothy Boltz, Talman Hylton, Angela Lamp, and Niles Ridgeway. Without their help, this achievement would not have been possible. Finally, I would like to thank my husband, Joshua Ayres, my parents, Richard and Janet Polentz, my sister, Alexandra Polentz, my grandparents, Ed Gayhart and Angee Polentz, and my late grandparents, Jay Polentz and Iris Sayre. I have been overwhelmed with your continuous support and encouragement; I would not be the person I am today without you. 


\section{TABLE OF CONTENTS}

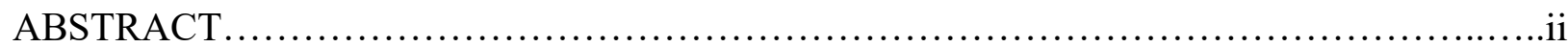

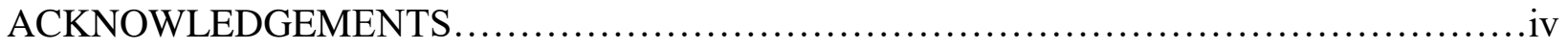

TABLE OF CONTENTS ................................................................

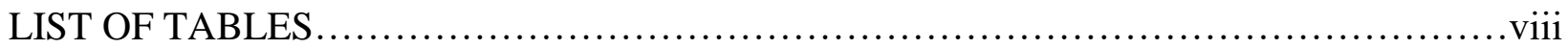

ABBREVIATION KEY ..................................................................

\section{CHAPTER ONE}

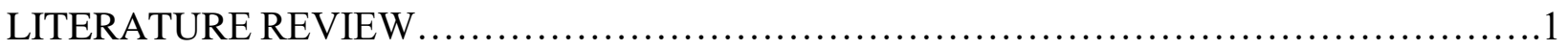

I. ANTI- NUTRITIVE FACTORS ..............................................

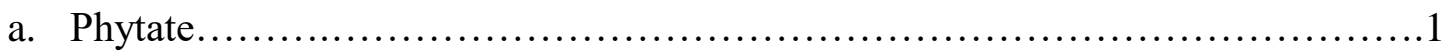

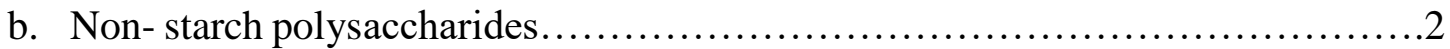

II. ENZYME SUPPLEMENTATION_.........................................

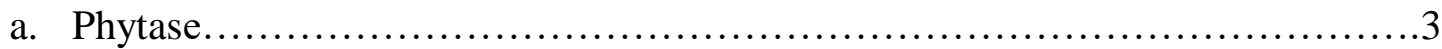

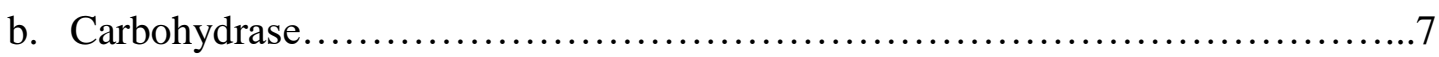

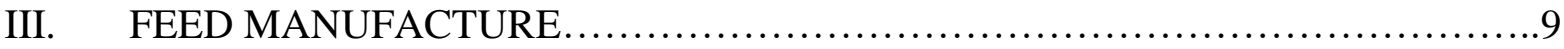

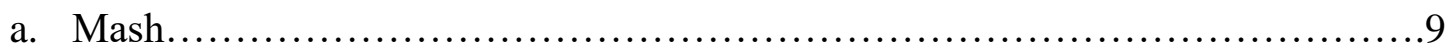

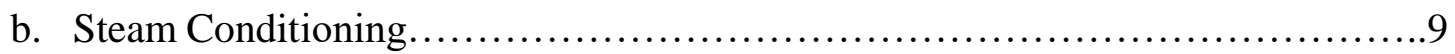

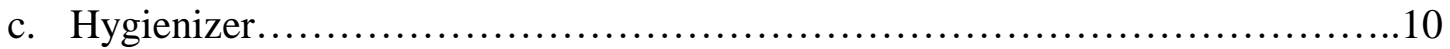

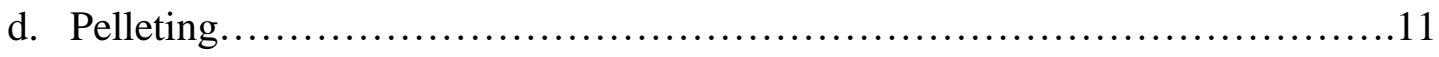

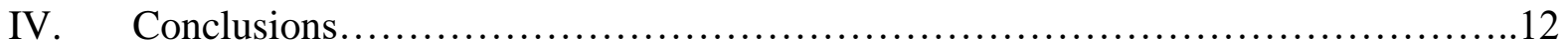

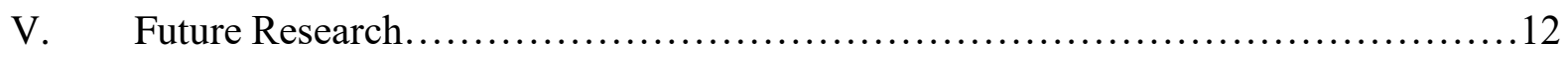

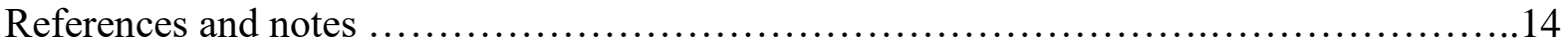




\section{CHAPTER TWO}

VISCOSITY AND GROWTH RESPONSE OF BROILERS FED HIGH FIBER DIETS SUPPLEMENTED WITH A CORN-PRODUCED RECOMBINANT CARBOHYDRASE......19

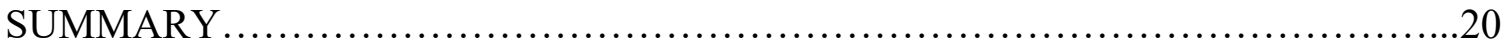

DESCRIPTION OF THE PROBLEM...........................................

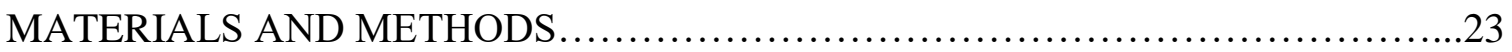

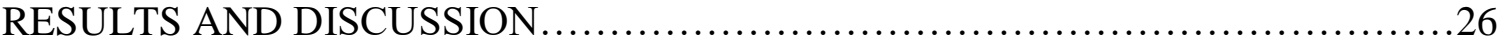

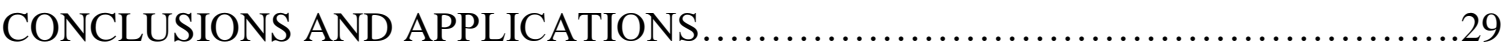

REFERENCES AND NOTES...................................................

Table 1: Diet Formulations fed for 21d trial............................................36

Table 2: Viscosity of three wheat sources analyzed prior to diet formulation..............37

Table 3: Particle size, glucanase activity, and dietary (in vitro) viscosity in the complete

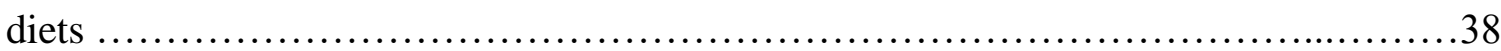

Table 4: D14 digesta viscosity of broilers fed diets with or without AC1 enzyme

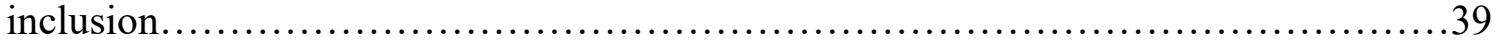

Table 5: Growth performance of broilers when fed diets with or without AC1 enzyme inclusion. 40

Table 6: Pearson correlation coefficients of intestinal viscosity and performance variables

Table 7: Pearson correlation coefficients of intestinal viscosity, dietary viscosity, and performance variables among all treatments analyzed categorically

\section{CHAPTER THREE}

EXOGENOUS ENZYME SUPPLEMENTATION CAN OVERCOME AMINO ACID DEFICIENT DIETS

SUMMARY 
MATERIALS AND METHODS...................................................... 46

RESULTS AND DISCUSSION .............................................. 49

CONCLUSIONS AND APPLICATIONS......................................... 51

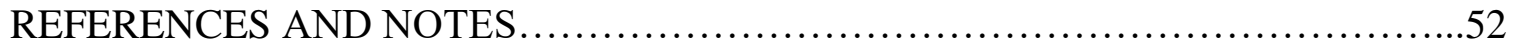

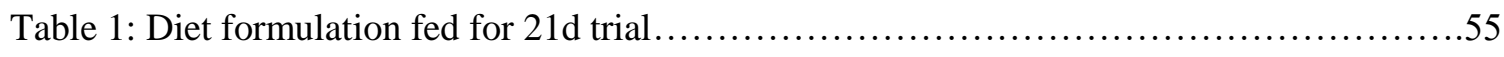

Table 2: Descriptive feed manufacture data from WVU Feed Mill on January 16, 2019. Pellets were manufactured using a 40 Horsepower California Pellet Mill and were extruded through a 4.8 x $38 \mathrm{~mm}$ pellet die..................................................56

Table 3: Mash and Pellet Moisture....................................................57

Table 4: Growth performance of broilers fed diets varying in enzyme supplementation...58

\section{CHAPTER FOUR}

THE EFFECT OF CORN-EXPRESSED CARBOHYDRASE ON PERFORMANCE AND DIGESTA VISCOSITY OF BROILERS FED A HIGH NON-STARCH POLYSACCHARIDE

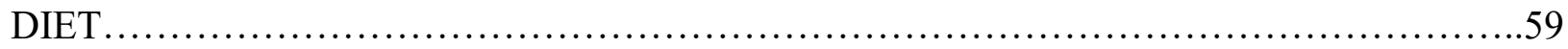

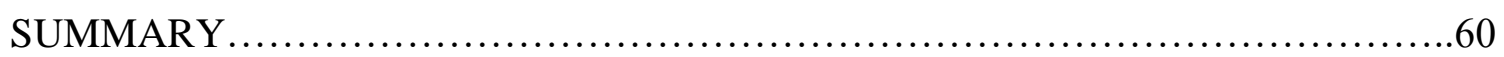

DESCRIPTION OF THE PROBLEM..........................................61

MATERIALS AND METHODS...................................................62

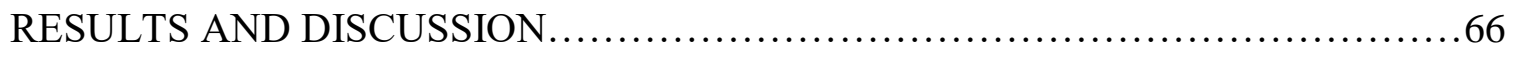

CONCLUSIONS AND APPLICATIONS......................................68

REFERENCES AND NOTES...................................................

Table 1. Ingredient composition of experimental diets from 1 to $21 \mathrm{~d}$...................72

Table 2. AC1 $\beta$-glucanase activity in 10 mash diet samples to determine homogeneity....73

Table 3. AC1 $\beta$-glucanase activity in feed before (mash) and after pelleting at different

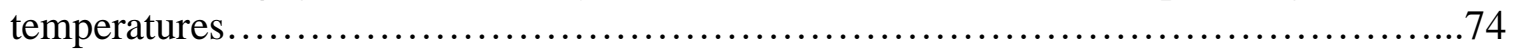

Table 4. Growth performance of Hubbard x Cobb 500 straight-run broilers fed a corn, soybean meal, wheat, and DDGS diet with various AC1 concentrations......

Table 5. Digesta viscosity of Hubbard x Cobb 500 straight-run broilers fed a corn, SBM, wheat, and DDGS diet with various $\mathrm{ACl} 1$ concentrations..............................76 


\section{LIST OF TABLES}

\section{CHAPTER TWO}

Table 1: Diet Formulations fed for $21 \mathrm{~d}$ trial...........................................

Table 2: Viscosity of three wheat sources analyzed prior to diet formulation.............37

Table 3: Particle size, glucanase activity, and dietary (in vitro) viscosity in the complete

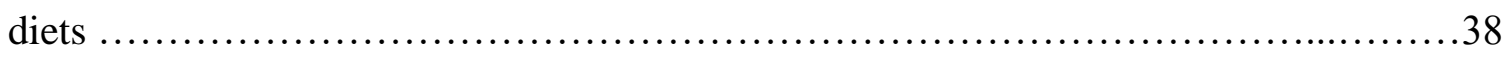

Table 4: D14 digesta viscosity of broilers fed diets with or without AC1 enzyme

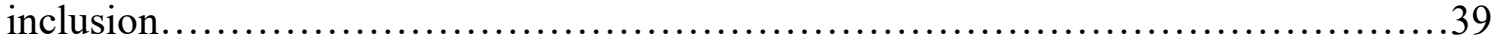

Table 5: Growth performance of broilers when fed diets with or without AC1 enzyme inclusion..............................................................40

Table 6: Pearson correlation coefficients of intestinal viscosity and performance variables

Table 7: Pearson correlation coefficients of intestinal viscosity, dietary viscosity, and performance variables among all treatments analyzed categorically

\section{CHAPTER THREE}

Table 1: Diet formulation fed for 21d trial

.55

Table 2: Descriptive feed manufacture data from WVU Feed Mill on January 16, 2019. Pellets were manufactured using a 40 Horsepower California Pellet Mill and were extruded through a $4.8 \times 38 \mathrm{~mm}$ pellet die. .56

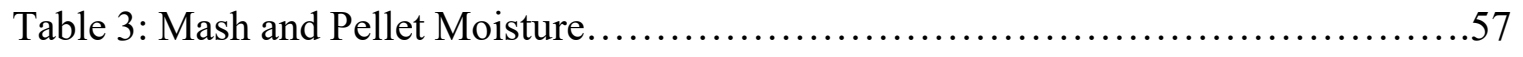

Table 4: Growth performance of broilers fed diets varying in enzyme supplementation...58

\section{CHAPTER FOUR}

Table 1. Ingredient composition of experimental diets from 1 to $21 \mathrm{~d}$. .72 
Table 2. AC1 $\beta$-glucanase activity in 10 mash diet samples to determine homogeneity....73

Table 3. AC1 $\beta$-glucanase activity in feed before (mash) and after pelleting at different temperatures........................................................... 74

Table 4. Growth performance of Hubbard x Cobb 500 straight-run broilers fed a corn, soybean meal, wheat, and DDGS diet with various AC1 concentrations............... 75

Table 5. Digesta viscosity of Hubbard x Cobb 500 straight-run broilers fed a corn, SBM, wheat, and DDGS diet with various $\mathrm{AC} 1$ concentrations........................... 76

\section{ABBREVIATION KEY}

\section{CHAPTER ONE}

1. Phosphorous- $\mathrm{P}$

2. National Research Council- NRC

3. Non-phytate phosphorous- nPP

4. Non-starch polysaccharide- NSP

5. Distillers' dried grains with solubles- DDGS

6. Fytase unit- FTU

7. Body weight gain- BWG

8. Feed conversion ratio- FCR

9. Feed intake- FI

10. Live weight gain- LWG

11. Pellet durability index-PDI

12. Modified pellet durability index- MPDI

13. True amino acid digestibility- TAAD

\section{CHAPTER TWO}

1. Non-starch polysaccharide- NSP

2. Distillers' dried grains with solubles- DDGS 
3. Corn-produced recombinant enzyme- AC1

4. Corn-soybean meal based diet- PC_1

5. Corn-soybean meal based diet with $10 \%$ inclusion of wheat and DDGS- PC_2

6. Negative Control- NC

7. $\mathrm{U} \beta$-Glucanase per $\mathrm{kg}$ of feed- $\beta$-Glu-U

8. Feed conversion ratio- FCR

9. Live weight gain- LWG

10. Anti-nutritive factor- ANF

11. Feed intake- FI

\section{CHAPTER THREE}

1. Positive Control- PC

2. Negative Control- NC

3. Non-starch polysaccharide enzyme- NSPase

4. Nitrogen- $\mathrm{N}$

5. Amino acid- AA

6. Non-starch polysaccharide- NSP

7. Feed conversion ratio- FCR

8. Metabolizable energy- ME

9. Hot pellet temperature- HPT

10. Pellet durability index-PDI

11. Modified pellet durability index-MPDI

12. Gastrointestinal- GI

13. Feed intake- FI

14. Live weight gain- LWG

15. Fisher's least significant difference- LSD 
16. Non-phytate phosphorous- nPP

17. Crude protein- $\mathrm{CP}$

\section{CHAPTER FOUR}

1. Corn-expressed carbohydrase- AC1

2. Positive control- PC

3. Negative control- NC

4. Corn derived distillers' dried grains with solubles- DDGS

5. $\mathrm{U} \beta$-Glucanase per $\mathrm{kg}$ of feed- $\beta$-Glu-U

6. Live weight gain- LWG

7. Anti-nutritional factors- ANF

8. Non-starch polysaccharide- NSP

9. Feed intake- FI

10. Feed conversion ratio- FCR

11. Fisher's least significant difference- LSD 


\section{CHAPTER ONE}

\section{LITERATURE REVIEW}

\section{Anti- nutritive factors}

\section{Phytate}

Phosphorous $(\mathbf{P})$ is included in poultry diets to aid in bone development and is essential for the utilization of energy. Phytic acid, myo-inositol hexaphosphoric acid, is an abundant compound in all seeds such as cereal grains and oilseeds. This compound also serves as the primary storage form of $\mathrm{P}$ in plants [1]. When $\mathrm{P}$ or other minerals are bound to phytic acid, the compound is known as phytin [2]. In commercial broiler diets, the majority of $\mathrm{P}$ is bound to phytate (myo- inositol hexakisphosphate, IP6). Studies report $60-70 \%$ of the P included in poultry feed is bound to phytic acid [3]. However, phytate is an anti-nutritive factor. Phosphorous becomes less available to the animal when bound to phytate, as poultry do not inherently obtain the phytase enzyme to free all of the bound $\mathrm{P}[4,5]$.

Phosphorous is crucial for proper skeletal growth and integrity as well as growth performance. However, because $\mathrm{P}$ is bound to phytate, it is often given in moderately excessive amounts than what is recommended by the National Research Council (NRC) to guarantee a safety margin [6]. Roberson et al. [7] found increased tibia strength and bone ash at 15 and 17 weeks of age when turkey toms were fed diets containing $145 \%$ versus 100 or $75 \%$ of the NRC recommended levels of $\mathrm{Ca}$ and non-phytate phosphorous (nPP). Along with increased tibia strength and bone ash, litter P was also increased [7].

While there are advantages for feeding $\mathrm{P}$ in higher quantities, the unabsorbed $\mathrm{P}$ is excreted in the manure and accumulates in the soil, leading to run-off. With the addition of nitrogen, these compounds can have harmful effects on the environment, causing eutrophication, which is a 
detrimental condition in aquatic areas, leading to fish kills and algal blooms [4, 8]. These high levels of $\mathrm{P}$ are the most common cause of waterway eutrophication [9].

\section{Non-starch polysaccharides}

In the United States, the primary cereal grains used in diet formations are corn and soybeans. However, the least-cost diet formulation often requires using other grains or agricultural byproducts, which may contain variable levels of anti-nutritive factors. The cell wall of cereals is composed primarily of complex carbohydrates, which are loosely termed "non-starch polysaccharides (NSPs) [10]. Corn derived distillers' dried grains with solubles (DDGS) is a byproduct of ethanol production and contains higher amounts of NSPs relative to corn [11]. Other cereal grains, such as wheat, also contain higher levels of NSPs. Annison and Choct [10] found that arabinoxylans found in wheat severely affected broilers' growth and feed conversion efficiency. The study also found that wheat pentosans caused a general inhibition of nutrient digestion, which affected starch, fat, and protein [10]. One explanation of how pentosans elicit an anti-nutritive effect is by influencing the rate of passage of digesta. Non-starch polysaccharides increase digesta viscosity, reducing the rate of passage of digestive enzymes and do not allow mixing with gut contents $[12,13]$. Other authors have also reported that the presence of NSPs can lead to increased intestinal viscosity, reduced nutrient digestibility, increased FCR, and decreased bird performance [14-17].

\section{Enzyme Supplementation}

According to Khattack and coauthors [18], an enzyme's essential characteristic is to catalyze the rate of a reaction but is not themselves altered by it. Enzymes are involved in all anabolic and catabolic pathways of digestion and metabolism and are specific catalysts acting on one or limited groups of substrates [18]. Ravindran [19] reported that the potential nutritive value of ingredients 
is not realized at the bird level and there is no common feed ingredient that is digested $100 \%$. Therefore, the need to improve the digestion of these undigested substrates is the primary rationale for the use of exogenous enzymes [19]. However, enzymes can improve other aspects of the poultry industry as well. For instance, the range of feedstuffs utilized may be increased, as well as the flexibility in diet formulations [20]. Variability in the nutritive value between batches of ingredients may also be reduced and gut health can be improved [20]. As intestinal morphology improves, excreta moisture content has also been shown to decrease [21,22], as well as manure output. Animals have also been shown to have more uniformity at the time of market [19].

\section{Phytase}

A common exogenous enzyme utilized in many commercial poultry operations is known as phytase. Many animal nutritionists use exogenous phytase to enable the animal to absorb more $\mathrm{P}$ and reduce environmental pollution. Phytases may be defined as phosphatase enzymes able to catalyze the hydrolysis of phosphate ester bonds [2]. In order to release the $\mathrm{P}$ from phytate, the phytate must first be hydrolyzed into inorganic P. This dephosphorylation of phytic acid is the result of phytase activity. Phytases make up a family of enzymes that activate the release of inorganic orthophosphate from phytate in a step-wise manner, which produces five classes of intermediate products [23]. These enzymes are classified in one of two categories: 3-phytases and 6-phytases. The 3-phytases begin the dephosphorylation of phytic acid at the third carbon on the inositol ring, while 6-phytases begin dephosphorylation at the sixth carbon [24]. While the complete hydrolysis of phytic acid is possible in a lab setting, Cowieson and coauthors demonstrated that, on average, 4 phosphate moieties were removed from the inositol ring and made available for retention by the birds [25]. Maenz also notes that the full sequence of hydrolysis of phytic acid down to myoinositol has yet to be determined [26]. 
Several feed ingredients such as wheat, barley, and wheat bran are rich in phytase activity, while corn, sorghum, oats, and oilseed meals are not [23]. The addition of phytase not only improves the absorption of $\mathrm{P}$, but also other minerals such as calcium, magnesium, zinc, and iron $[1,27]$. Officer and Batterham [28] also found improvements of ileal digestibility of protein and essential amino acids in pigs, with the addition of phytase. Nitrogen digestibility has been shown to improve with this supplementation as well [29-31]. Shirley and Edwards found that higher levels of phytase may also improve nutrient utilization [32]. However, there is high variability in phytase data such as dosage levels and other enzyme characteristics. Therefore, there is no specific requirement to include in the diet.

One phytase unit (FTU) is defined as the quantity of enzyme required to liberate $1 \mu \mathrm{mol}$ of inorganic $\mathrm{P} / \mathrm{min}$, at $\mathrm{pH} 5.5$, from an excess of $15 \mu \mathrm{M}$ sodium phytate at $37^{\circ} \mathrm{C}$ [33]. However, when calculating a dosage to include in the diet, caution should be utilized, as in-vitro retained activity may not always predict bird performance. Assays may also vary between companies [34].

Phytase activity was previously thought to plateau at 500 FTU in diets sufficient in total P $[35,36]$. This inclusion level is in agreement with Cowieson and coauthors [25]. In this experiment, it was found that little benefits were obtained by adding phytase above $600 \mathrm{FTU}$, while significant benefits were seen with the addition of 150 or 300 FTU. However, Shirley and Edwards [32] have shown that the addition of 12,000 FTU of phytase significantly improved bird performance. Not only did this addition improve the utilization of phytate bound $\mathrm{P}$, but also increased nitrogen retention by $33 \%$. Birds given the high dose of phytase were also able to utilize an additional $200 \mathrm{ME} / \mathrm{kg}$ diet. This suggests that the inclusion of phytase at higher levels may influence more than mineral utilization. Shirley and Edwards [32] also note that this increase in nutrient utilization may be due to the ability of phytase to disrupt various interactions between 
phytate, minerals, starch, and protein, thus allowing a greater utilization of all nutrients in the diet. Walk and coauthors [37] found that the supplementation of additional phytase (above 500 FTU) may improve feed efficiency in broilers by alleviating anti-nutritive factors, rather than solely releasing phytate bound P. Walk and coauthors [38] also investigated the effects of super-dosing phytase at 1,000 or $1,500 \mathrm{U} / \mathrm{kg}$. In this experiment, they found that the super-doses of phytase lead to almost total hydrolysis of phytate, an increase in inositol concentration in the gizzard, and improved broiler performance. When the negative control was supplemented with $1,500 \mathrm{U} / \mathrm{kg}$ of phytase, both feed intake (FI) and body weight gain (BWG) increased by $0.066 \mathrm{~kg}$ and $0.085 \mathrm{~kg}$, respectively. Consequently, feed conversion ratio (FCR) also improved by 0.05 points [38]. This data agrees with Cowieson and coauthors [25], as high doses of phytase improved apparent phytate $\mathrm{P}$ digestibility as well as total $\mathrm{P}$ digestibility compared to lower doses of phytase. This high inclusion of 24,000 FTU of phytase improved toe ash percentage by $3 \%$ and also improved the utilization of several nutrients more so than the lower inclusions.

Phytase is utilized by many commercial operations. Although, there is high variability in phytase data, as the phytase source may contribute to the varying characteristics and effectiveness of this enzyme. There are numerous commercially available phytases, both bacterial and fungal, which have been shown to increase FI, live weight gain (LWG), tibia ash percent and weight, and decrease FCR, ultimately improving bird performance $[25,38]$. Research conducted by Pillai and co-authors [39] found that phytase from bacteria improves growth, bone, and carcass performance. In this experiment, phytase sourced from bacteria was more efficient than fungal phytase products at releasing phytate-bound P. Li and coauthors [40] found that when supplementing 1000 FTU of phytase sourced from bacteria, FI increased by $124 \mathrm{~g} / \mathrm{bird}$, BW gain increased by $117 \mathrm{~g} / \mathrm{bird}$, and tibia ash weight also increased by $69 \mathrm{mg} /$ tibia. 
As an alternative to using exogenous phytase supplementation, genetic modifications have also been explored. These modifications have been implemented in several plant seeds to increase phytate-degrading activity. In 1993, Pen and coauthors [41] engineered a phytase from Aspergillus niger in tobacco seeds. This transgenic seed was comparable to that of fungal phytase or the addition of $\mathrm{P}$ in the diet, as growth rate was improved with this inclusion. However, tobacco seeds are not typically included in commercial poultry diets and more research was required. Denbow and coauthors [42] utilized this information and compared the effects of phytase as a commercial supplement and phytase as a recombinant protein in transformed soybeans. Adding 1200 FTU phytase as transformed seeds to the basal diet provided BWG similar to that of the basal diet supplemented with $0.24 \% \mathrm{nPP}$. When added on an equal activity basis, phytase from transformed soybeans or commercial microbial phytase were equally effective in enhancing BWG, FI, feed efficiency, toe ash, tibia shear force, and energy [42].

While this is valuable information, one must consider the thermal stability of the enzyme prior to transforming seeds. Soybeans must undergo thermal processing before their addition to the diet, which could damage the enzyme. Corn, however, is also commonly included in poultry diets, and is not subjected to thermal processing prior to its inclusion. With this knowledge, Nyannor and coauthors [43] utilized a corn expressing phytase. These authors found that, with the addition of transformed corn, digesta cell walls degraded more rapidly and phytic acid $\mathrm{P}$ concentration decreased in broiler chicks. In agreement with Nyannor and cohorts, Gao and coauthors [44] found that phytase expressed in corn had comparable results with commercial microbial phytases. This is in agreement with Naynorr and Adeola [45] that a corn-based phytase was as efficacious as a microbial phytase. These authors found that the corn-based phytase fed to broiler chicks resulted in an improvement in bone mineralization, comparable to that of a microbial 
expressed phytase [45]. In disagreement, Homan and Moritz [46] found that birds provided diets with a granulated bacterial phytase resulted in increased performance and tibia mineralization compared to broiler chicks fed mash diets with a transgenic phytase corn. The authors hypothesized that this difference could be due to variations in dispersion of enzyme within the diet. The transgenic phytase had a larger particle size than the granulated bacterial phytase, which the broilers would be less likely to consume, compared to the smaller more frequent particles of the granulated bacterial phytase. Also, differences may be due to the general effectiveness of the expressed enzyme, as the expression system of the granulated bacterial phytase may have been superior to the transgenic phytase corn [46].

\section{Carbohydrase}

Poultry do not naturally obtain adequate enzymes for the hydrolysis of NSPs in the cell walls of cereal grains; therefore, these NSPs often remained un-hydrolyzed and can result in low feed efficiency [18]. The negative effects associated with NSPs can be ameliorated by the supplementation of carbohydrases. These enzymes break down the NSPs, decrease intestinal viscosity, and can improve nutrient digestibility [18, 19, 47]. Similar to phytase, these NSPdegrading enzymes can be produced via microbial sources or produced through genetic modification.

Often times, enzyme "cocktails," containing a variety of enzymes, are supplemented into diet formulations. These cocktails make substrates more available for the enzymes to degrade. Meng and coauthors [17] found that by supplementing an enzyme cocktail supplying $100 \mathrm{U}$ of xylanase, $400 \mathrm{U}$ of glucanase, 1,000 $\mathrm{U}$ of pectinase, $120 \mathrm{U}$ of cellulose, $280 \mathrm{U}$ of mannase, and $180 \mathrm{U}$ of glactanase per kilogram of a corn based diet, broilers had an improved FCR. The authors also concluded that using an appropriate multi-carbohydrase enzyme supplement could enhance 
the nutrient utilization of a corn-soybean meal based diet [17]. Similar results were also observed by Coppedge and coauthors [48]. Birds were supplemented with an enzyme cocktail during the grower phase, which supplemented $1,500 \mathrm{U}$ of xylanase, $1,100 \mathrm{U}$ of $\beta$-glucanase, $35 \mathrm{U}$ of $\alpha$ galactosidase, and $110 \mathrm{U}$ of $\beta$-mannanase included in a corn and soybean meal based diet. These authors concluded that NSP-degrading enzymes had the potential to improve growth performance and processing parameters of broilers [48].

Carbohydrases are often supplemented with other enzymes such as proteases, which are necessary for protein digestion and to generate amino acids, and phytases. Many nutritionists utilize a combination of carbohydrases and proteases to improve nutrient retention and performance of chicks. Ravindran et al. [49] found that there were no negative interactions between phytase and xylanase in wheat-based diets. In fact, the inclusion of both enzymes may be advantageous. Cowieson and Adeola [50] also agreed that the combination of multiple enzymes was highly effective to improve broiler performance. Specifically, the addition of xylanase, amylase, protease and phytase can improve digestibility of nutrients and performance of birds fed a diet suboptimal in terms of $\mathrm{Ca}, \mathrm{P}$, and ME. Juanpere and coauthors [51] also examined the effects of a microbial 3-phytase and a glycosidase on corn, wheat, or barley based diets. These authors concluded that both enzymes acted independently of one another, and suggested that they may be combined in high NSP diets, without serious negative interactions. Olukosi and cohorts [52] also concluded that the combination of a phytase and an enzyme cocktail containing xylanase, amylase, and protease improved performance of chicks fed a corn-soybean meal based diet, marginally deficient in terms of energy and P. 


\section{Feed Manufacture}

Mash

In the United States, poultry diets are typically composed of several feedstuffs such as cereal grains, soybean meal, animal byproduct meals, fats and vitamin/mineral premixes. Along with water, these ingredients provide the bird with energy and nutrients that are critical for growth, reproduction, and health. [3]. The inclusion levels of these ingredients can vary between each batch and the type of bird that is being fed, as the least cost diet formulation is utilized [53]. Along with these ingredients, other supplements, including exogenous enzymes, probiotics, prebiotics, organic acids, and phytogenics may also be included in the diet. These ingredients are then blended together using a mixer. Feed mixers typically have ribbons and/or paddles inside to evenly blend the ingredients together [54]. After mixing, the ingredients can either be left as a mash feed or they can be further processed to become pelleted feed.

\section{Steam Conditioning}

If the feed is to be pelleted, it must first be conditioned. Conditioning equipment consists of a horizontal chamber, that applies steam to the mash feed before extrusion [55]. The temperature inside the conditioner and the time that the feed is inside the chamber can vary between formulation or customer/management desire. Increasing conditioning temperature improves pellet quality by increasing the heat and moisture within the feed [56]. Loar and cohorts [57] also reported increased pellet quality with an increase of conditioning temperature. Cutlip and coauthors [58] found that when compared to low conditioning temperatures, pellet durability index (PDI) and modified pellet durability index (MPDI) increased with conditioning temperatures. While high conditioning temperatures have been shown to increase pellet quality and improve feed hygienics, other consequences should also be taken into account. Homan and Moritz [46] found that when 
conditioning temperature was increased, broiler performance suffered as well as tibia mineralization. When examining various phytase products, these authors found that increased conditioning temperatures may have decreased nutrient availability, as well as denaturization of the phytase products.

Amino acids are also highly susceptible to heat. At high temperatures, the proteins in the feed could be denatured, which can be detrimental to the animals [58]. Loar and coauthors [57] found that when conditioning at $85^{\circ} \mathrm{C}$ and $96^{\circ} \mathrm{C}$, compared to $74^{\circ} \mathrm{C}$, true amino acid digestibility (TAAD) of Met, Ile, and Pro decreased by 3 to $5 \%(P<0.05)$ and Lys, Val, and Leu tended to decrease by 3 to $6 \%(P<0.10)$. In agreement with this study, Boney and coauthors also found that when diets were conditioned at $91^{\circ} \mathrm{C}$, several amino acids had decreased digestibility [59].

\section{Hygienizer}

A second piece of equipment utilized during the pelleting process is the hygienizer. Peisker [60] notes that while pelleting does have an effect on the hygienic status of the feed, a short-term conditioner alone or in combination with a pellet press, is not sufficient for decontamination of pathogenic microorganisms. However, sufficient decontamination can be achieved with the use of a hygienizer, a horizontal retention screw or vertical shaft [60]. Instead of adding steam to improve pellet quality like the conditioner, the hygienizer maintains feed temperature for an extended time to reduce the prevalence of harmful microorganisms like Salmonella. This pathogen, in particular, can persist for a long period of time in a variety of materials. It can also be found in feed mills and contaminate the feed being produced [61]. By utilizing the hygienizer, Salmonella and other microorganisms can be decreased, making the feed more sterile. Unfortunately, the full effects of the hygienizer on feed is unknown and more research is required. 


\section{Pelleting}

Pelleting can be defined as "a process that uses moisture, heat, and pressure to agglomerate smaller particles into larger particles" [62-64]. Pelleted feeds are often used in the commercial poultry industry. Steam is first added to mash feed for a certain length of time and at a specific temperature, both that can vary between operations. The mash feed is then extruded through a pellet die, which shapes the pellets. By pelleting feed, there is less ingredient segregation and, in theory, the animals receive each nutrient in every pellet [65]. Birds also expend less energy during consumption of pellets relative to consuming mash. The animal is able to utilize energy more efficiently, as they are spending less time grasping the feed, and the energy becomes available for other functions. Consequently, feed efficiency is improved, as well as growth uniformity [65]. In contrast, however, Glover and coauthors [66] found a greater coefficient of variation as birds given improved crumble/pellet percentage were also shown to have a higher within-pen variation in body weight. These authors concluded that the within-pen coefficient of variation of body weight may have partially been affected by the feeder space available. It is hypothesized that the larger, more dominant birds monopolized the feeder space access, allowing them to consume the majority of the crumbles/pellets and leaving the fines for the smaller, less-dominant birds [66].

Feed form is also an important factor to consider. Massquetto and coauthors [67] concluded that when feed form is improved, FI, weight gain, and ileal digestibility of dry matter, crude protein, and energy are also increased. Cutlip and coauthors [58] also noted that small improvements in pellet quality may also improve feed efficiency while maintaining a similar weight gain. Lilly and coauthors [68] observed similar results, as birds fed medium or high pellet quality diets consumed more feed than those fed low quality pellets. Consequently, the medium 
and high pellet quality diets increased LWG and carcass weight compared to the low pellet quality diet. However, the variation of feed form had a lesser effect on FCR.

\section{Conclusions}

In conclusion, anti- nutritive factors such as phytate and NSPs are found in various feedstuffs and ingredients utilized in broiler diets. By including these ingredients, however, the least cost diet formulation may be achieved. With the inclusion of phytase in the diet, broiler chickens are better able to utilize $\mathrm{P}$. This is not only beneficial for the bird, as $\mathrm{P}$ is imperative for energy and growth, but also for the environment as the combination of $\mathrm{P}$ and $\mathrm{N}$ can lead to eutrophication of waterways. In addition to phytate, NSPs can impair the digestive system, as digesta viscosity has been shown to increase with diets containing a high concentration of NSPs. When the digesta is more viscous, nutrients become less available to the bird and are more difficult for the bird to absorb. However, these negative effects associated with NSPs can be ameliorated when carbohydrases are included in the diet. Similar to phytase, carbohydrases allow producers to achieve the least cost diet formulation, as these enzymes enable the animal to utilize more nutrients. Both enzymes are traditionally produced via microbial sources; however, there is much research to be completed concerning transgenic enzymes.

\section{Future Research}

While most enzymes are produced by bacterial or fungal sources, it is imperative that the poultry industry studies the use of transgenic enzymes as well. Multiple studies have shown that transgenic enzymes have similar efficacy as the traditional, microbial produced enzymes. However, prior to their use in poultry diets, they must be examined for thermal stability. Poultry feed is often pelleted in the commercial industry and is subjected to high temperatures. These temperatures could denature the enzymes, ultimately decreasing enzyme activity. Therefore, it is 
imperative to perform additional analyses on transgenic enzymes when exposed to high temperatures during the pelleting process. 


\section{REFERENCES AND NOTES}

1. Maga, J.A. 1982. Phytase: Its Chemistry, Occurrence, Food Interactions, Nutritional Significance, and Methods of Analysis. Journal of Agricultural and Food Science. 30:1-9.

2. Angel, R., N.M. Tamin, T.J. Applegate, A.S. Dhandu, and L.E. Ellestad. 2002. Phytic Acid Chemistry: Influence on Phytin-Phosphorus Availability and phytase Efficacy. J. Appl. Poult. Res. 11:471-480.

3. NRC. 1994. Nutrient Requirements of Poultry. 9th rev. ed. Natl. Acad. Press, Washington, DC.

4. Adeola, O. and J. S. Sands. 2003 Does supplemental dietary microbial phytase improve amino acid utilization? A perspective that it does not. J. Anim. Sci. 81:78-85.

5. Bedford, M.R. and H. Schulze. 1998 Exogenous enzymes for pigs and poultry. Nut. Res. Rev. 11:91-114.

6. Waldroup, P.W. 1999. Nutritional approaches to reducing phosphorus excretion by poultry. Poult. Sci. 78:683-691.

7. Roberson, K.D., M.W. Klunzinger, and R.A. Charbeneau. 2004. Benefit of feeding dietary calcium and nonphytate phosphorus levels above national research council recommendations to tom turkeys in the growing-finishing phases. Poult. Sci. 83:689-695.

8. Sharpley. 1991. Agricultural phosphorus, water quality, and poultry production: are they compatible?. Poult. Sci. 78:660-673.

9. Correll, D.L.1999. Phosphorus: a rate limiting nutrient in surface waters. Poult. Sci. 78:674-682.

10. Annison, G. and M. Choct. 1991. Anti-nutritive activities of cereal non-starch polysaccharides in broiler diets and strategies minimizing their effects. World's Poultry Science Journal. 47:232-242.

11. Min, Y.N., F. Yan, F.Z. Liu, C. Coto, and P.W. Waldroup. 2009. Effect of various dietary enzymes on energy digestibility of diets high in distillers dried grains with solubles for broilers. J. Appl. Poult. Res. 18:734-740.

12. Antoniou, T., R.R. Marquardt, and E. Cansfield. 1981. Isolation, partial characterization, and antinutirional activity of a factor (pentosans) in rye grain. Journal of Agriculture and Food Chemistry. 29:1240-1247.

13. Antoniou, T. and R.R. Marquardt. 1982. The utilization of rye by growing chicks as influenced by autoclave, treatment, water extraction and water soaking. Poult. Sci. 61:91102.

14. Bedford, M. R., and H. L. Classen. 1992. Reduction of intestinal viscosity through manipulation of dietary rye and pentosanase concentation is effected through changes in the carbohydrate composition of the intestinal aqueous phase and results in improved growth rate and food conversion efficiency of broiler chicks. J. Nutr. 122:560-569.

15. Bedford M. R., and A. J. Morgan. 1996. The use of enzymes in poultry diets. World's Poult. Sci. J. 52:61-68.

16. Lázaro, R., M. Gracia, M. J. Aranibar, and G. G. Mateos. 2003. Effect of enzyme addition to wheat-, barley- and rye-based diets on nutrient digestibility and performance of laying hens. Br. Poult. Sci. 84:37-47. 
17. Meng, X., and B. A. Slominski. 2005. Nutritive values of corn, soybean meal, canola meal, and peas for broiler chickens as affected by a multicarbohydrase preparation of cell wall degrading enzymes. Poult. Sci. 84:1242-1251.

18. Khattack, F.M., T.N. Pasha, and A. Mahmud. 2006. Enzymes in poultry nutrition. J. Anim. Pl. Sci. 16:1-7.

19. Ravindran, V. Feed enzymes: The science, practice, and metabolic realities. 2013. J. Appl. Poult. Res. 22:628-636.

20. Bedford, M.R., and A.J. Cowieson. 2012. Exogenous enzymes and their effects on intestinal microbiology. Anim. Feed Sci. Technol. 173:76-85.

21. Viveros, A., A. Brenes, M. Pizarro, and M. Castaño. 1994. Effect of enzyme supplementation of a diet based on barley, and autoclave treatment, on apparent digestibility, growth performance and gut morphology of broilers. Anim. Feed Sci. Technol. 48:237-251.

22. Jaroni, D., S.E. Scheideler, M.M. Beck, and C. Wyatt. 1999. The effect of dietary wheat middlings and enzyme supplementation II: Apparent nutrient digestibility, digestive tract size, guts viscosity, and gut morphology in two strains of Leghorn hens. Poult. Sci. 78:1664-1674.

23. Ravindran, V., W.L. Bryden, E.T. Kornegay. 1995. Phytases: Occurrence, bioavailability, and implications in poultry nutrition. Poult. Avian Biol. Rev. 6:125-143.

24. Selle, P.H. and V. Ravindran. 2006. Microbial phytase in poultry nutrition. Anim. Feed Sci. and Tech. 135:1-41.

25. Cowieson, A.J., T. Acamovic, and M.R. Bedford. 2006. Supplementation of Corn-SoyBased Diets with an Eschericia coli- Derived Phytase: Effects on Broiler Chick Performance and the Digestibility of Amino Acids and Metabolizability of Minerals and Energy. Poult. Sci. 85:1389-1397.

26. Maenz, D.D. 2001. Enzymatic characteristics of phytases as they relate to their use in animal feeds. Pages 61-84 in Enzymes in Farm Animal Nutrition.

27. Paullauf, J., D. Hohler, G. Rimbach, and H. Neusser. 1992. Influence of an addition of microbial phytase to a corn-soy diet on the apparent absorption of $\mathrm{P}$ and calcium in the piglet. J. anim. Physiol. Anim. Nutr. 67:30-40.

28. Officer, D.I., and E.S. Batterham. 1992. Enzyme supplementation of linola meal for pigs. Proc. Aust. Soc. Anim. Prod. 9:288.

29. Van der Klis, J.D., and H.A.J. Versteegh. 1991. Ileal absorption of $P$ in lightweight white laying hens using microbial phytase and various calcium contents in laying hen feed. Spelderholt publication No. 563.

30. Mroz, Z., A.W. Jongbloed, and P.A. Kemme. 1994. Apparent digestibility and retention of nutrients bound to phytate complexes as influenced by microbial phytase and feeding regimen in pigs. J. Anim. Sci. 72:126-132.

31. Yi, Z., E.T Kornegay, V. Ravidran, and D.M. Denbow. 1994. Improving availability of corn and soybean meal $\mathrm{P}$ for broilers using Natuphos ${ }^{\circledR}$ phytase and calculation of replacement values of inorganic $P$ by phytase. Poult. Sci. 73(Suppl. 1):89.

32. Shirley, R.B. and H.M. Edwards, Jr. 2003. Graded Levels of Phytase Past Industry Standards Improves Broiler Performance. Poult. Sci. 82:671-680. 
33. International Union of Biochemistry. 1979. Enzyme Nomenclature: Recommendation of the Nomenclature committee of the International Union of Biochemistry. Academic Press, New York, NY.

34. Loop, S.A., K.G.S. Lilly, L.K. Shires, C.K. Gehring, K.R. Beanman, M.E. Persia, and J.S. Moritz. 2012. The phytase analytical activity of pelleted diets may not adequately describe efficacy in the bird. J. Appl. Poult. Res. 21:492-501.

35. Simons, P.C.M., H.A.J. Versteegh, A.W. Jongbloed, P.A. Kemme, P. Slump, K.D. Bos, M.G.E. Wolters, R.F. Beudeker, and G.J. Verschoor. 1990. Improvement of P availability by microbial phytase in broilers and pigs. Br. J. Nutr. 64:525-540.

36. Huyghebaert, G., G. de Groote, and C. Geerse. 1992. Effect of microbial phytase on the utilization of $\mathrm{P}$ by broiler chickens. 1. Effect on the availability of $\mathrm{P}$ and calcium. Rev. Agric. 45:217-228.

37. Walk, C.L., M.R. Bedford, T.S. Santos, D. Paiva, J.R. Bradley, H. Wladecki, C. Honaker, and A.P. McElroy. 2013. Extra-phosphoric effects of superdoses of a novel microbial phytase. Poult. Sci. 92:719-725.

38. Walk, C.L., T.T. Santos, and M.R. Bedford. 2014. Influencce of superdoses of a novel microbial phytase on growth performance, tibia ash, and gizzard phytate and inositol in young broilers. Poult. Sci. 93:1172-1177.

39. Pillai, P.B., T. O’Connor-Dennie, C.M. Owens, and J.L. Emmert. 2006. Efficacy of an Escherichia coli Phytase in Broilers Fed Adequate or Reduced P Diets and Its Effect on Carcass Characteristics. Poult. Sci. 85:1737-1745.

40. Li, W., R. Angel, S.W. Kim, E. Jiménez-Moreno, M. Proskowiec-Weglarz, and P.W. Plumstead. 2015. Impact of response criteria (tibia ash weight vs. percent) on phytase relative non phytate P equivalence. Poult. Sci. 94:2228-2234.

41. Pen J., T.C. Verwoerd, P.A. van Paridon, R.F. Beudeker, P.J.M. van den Elzen, K. Geerse, J.D. van der Klis, H.A.J. Versteegh, A.J.J. van Ooyen, and A. Hoekema. 1993. Phytase-containing transgenic seeds as a novel feed additive for improved P utilization. Nat. Biotechnol. 11:811-814.

42. Denbow, D.M., E.A. Grabau, G.H. Lacey, E.T. Kornegay, D.R. Russell, and P.F. Umbeck. 1998. Soybeans transformed with a fungal phytase gene improve P availability for broilers. Poult. Sci. 77:878-881.

43. Nyannor, E.K.D., M.R. Bedford, and O. Adeola. 2009. Corn expressing Escherichia coliderived phytase gene: Residual phytase activity and microstructure of digesta in broiler chicks. Poult. Sci. 88:1413-1420.

44. Gao, C.Q., C. Ji, L.H. Zhao, J.Y. Zhang, and Q.G. Ma. 2013. Phytase transgenic corn in nutrition of laying hens: Residual phytase activity and phytate $\mathrm{P}$ content in the gastrointestinal tract. Poult. Sci. 92:2923-2929.

45. Naynorr, E.K.D. and O. Adeola. 2008. Corn expressin an Escherichia Coli- Derived Phytase Gene: Comparative Evaluation Study in Broiler Chicks. Poult. Sci. 87:20152022.

46. Homan, V. and J.S. Moritz. 2016. Conditioning Thermal Stability and Dose Effects of Commercially Available Phytase Preparations on Performance and Tibia Mineralization 
of Young Broiler Chickens. Thesis submitted to the Davis College of Agriculture and Design at West Virginia University.

47. Bedford, M.R. 2000. Exogenous enzymes in monogastric nutrition - their current value and future benefits. Animal Feed Science and Technology. 86:1-13.

48. Coppedge, J.R., L.A. Oden, B. Ratliff, B. Brown, and J.T. Lee. 2012. Evaluation of nonstarch polysaccharide- degrading enzymes in broiler diets varying in nutrient and energy levels as measured by broiler performance and processing parameters. J. Appl. Poult. Res. 21:226-234.

49. Ravindran, V., P.H. Selle, and W.L. Bryden. 1999. Effects of Phytase Supplementation, Individually and in Combination, with Glycanase, on the Nutritive Value of Wheat and Barley. Poult. Sci. 78:1588-1595.

50. Cowieson, A.J. and O. Adeola. 2005. Carbohydrases, Protease, and Phytase Have an Additive Beneficial Effect in Nutritionally Marginal Diets for Broiler Chicks. Poult. Sci. 84:1860-1867.

51. Juanpere, J., A.M. Pérez-Vendrell, E. Angulo, and J. Brufau. 2005. Assessment of potential interactions between phytase and glycosidase enzyme supplementation on nutrient digestibility in broilers. Poult. Sci. 84: 571-580.

52. Olukosi, O.A., A.J. Cowieson, and O. Adeola. 2007. Age-related influence of a cocktail of xylanase, amylase, and protease or phytase individually or in combination in broilers. Poult. Sci. 86: 77-86.

53. Thomas, M., T. Van Vliet, and A. F. B. Van der Poel. 1998. Physical quality of pelleted animal feed 3. Contribution of feedstuff components. Animal Feed Science and Technology. 70: 59-78.

54. Martin, S. 2005. Hayes and Stolz Industrial Manufacturing Company, Inc. Feed Manufacturing Technology V. American Feed Industry Association. Pages 137-141.

55. Kobetz, R., K. Kobetz, Sunfield Engineering. 2005. Feed Manufacturing Technology V. American Feed Industry Association. Page 43-57.

56. Fairfield, D.A. 2003. Pelleting for profit. National Grain and Feed Association. Feed and Feeding Digest. Vol. 54. N. 6.

57. Loar II, R.E., K.G.S. Wamsley, A. Evans, J.S. Moritz, and A. Corzo. 2014. Effects of varying conditioning temperature and mixer-added fat on feed manufacture efficiency, 28- to 4-day broiler performance, early skeletal effect, and true amino acid digestibility. J. Appl. Poult. Res. 23:444-455.

58. Cutlip, S.E., J.M. Hott, N.P. Buchanan, A.L. Rack, J.D. Latshaw, J.S. Moritz. 2008. The Effect of Steam-Conditioning Practices on Pellet Quality and Growing Broiler Nutritional Value. J. Appl. Poult. Res. 17:249-261.

59. Boney, J.W. and J.S. Moritz. 2017. The effects of Spirulina algae inclusion and conditioning temperature on feed manufacture, pellet quality, and true amino acid digestibility. Animal Feed Science and Technology. 224:20-29.

60. Peisker, M. 2006. Feed Processing- Impacts on Nutritive Value and Hygienic Status in Broiler Feeds. Aust. Poult. Sci. Symp. 18.

61. Jones, F.T. 2011. A review of practical Salmonella control measures in animal feed. J. Appl. Poult. Res. 20:102-113. 
62. Skoch, E. R., K.C. Behnke, C.W. Deyoe, \& S.F. Binder. 1981. The effect of steamconditioning rate on the pelleting process. Animal Feed Science and Technology. 6:8390.

63. Falk, D. Pelleting cost center. Feed Manufacturing Technology III (Ed. RR Mcellhiney). 167-190.

64. Huang, X., C. Christensen, and P. Yu. 2015. Effects of conditioning temperature and time during the pelleting process on feed molecular structure, pellet durability index, and metabolic features of co-products from bio-oil processing in dairy cows. J. Dairy Sci. 98:4869-4881.

65. Scheideler, S.E. 1991. Pelleting is Important for Broilers. Pages 1-7 Proc. $18^{\text {th }}$ Annu. Carolina Poult. Nutr. Conf., Charlotte, NC. North Carolina State Univ., Raleigh.

66. Glover, B.G, K.L. Foltz, I. Holásková, and J.S. Moritz. 2016. Effects of modest improvements in pellet quality and experiment pen size on broiler chicken performance. J. Appl. Poult. Res. 25:21-28.

67. Massuquetto, A., J.F. Durau, V.G. Schramm, M.V.T. Netto, E.L. Krabbe, and A. Maiorka. 2017. Influence on feed form and conditioning time on pellet quality, performance, and ileal nutrient digestibility in broilers. J. Appl. Poult. Res. 0:1-8.

68. Lilly, K. G. S., C. K. Gehring, K. R. Beaman, P. J. Turk, M. Sperow, J. S. Moritz. 2011. Examining the relationships between pellet quality, broiler performance, and bird sex. J. of Applied Poult. Res. 20:231-239. 


\section{CHAPTER TWO}

Viscosity and growth response of broilers fed high fiber diets supplemented with a corn-produced recombinant carbohydrase

V.E. Ayres ${ }^{1}$, J.N. Broomhead ${ }^{2}$, X. $\mathrm{Li}^{2}$, R.M. Raab ${ }^{2}$, and J.S. Moritz ${ }^{1}$

${ }^{1}$ Division of Animal and Nutritional Sciences, West Virginia University, Morgantown,

West Virginia, 26506

Phone: 304-293-1911

Fax: 304-293-2232

${ }^{2}$ Agrivida Inc., Boston, MA 
SUMMARY Feed ingredients containing high levels of non-starch polysaccharides (NSP), such as wheat and corn distillers' dried grains with solubles (DDGS), can form viscous digesta in the gastrointestinal tract, limiting broiler performance. A study was conducted to determine efficacy of a corn-produced recombinant carbohydrase (AC1) on dietary and intestinal viscosity and broiler performance with a high NSP diet. Hubbard x Ross 708, day-old, male broiler chicks ( $\mathrm{n}=960$ ) were fed one of eight dietary treatments for 21d. Diets included a corn-soybean meal based diet (PC_1) and a diet of similar essential nutrient density, but with a $10 \%$ inclusion of both wheat and DDGS (PC_2) and a negative control (NC) with similar ingredients as PC_2, but with ME reduced by $125 \mathrm{kcal} / \mathrm{kg}$. Additional treatments had varying levels of AC1, supplying 50, 100, 200, 400, or 600 U $\beta$-Glucanase ( $\beta$-Glu-U) per kg of feed, mixed into the NC diet. Dietary and digesta (d14) viscosity and weekly bird performance were measured. The inclusion of wheat and DDGS increased d1-7 feed conversion ratio (FCR) and supplementing AC1 at 50-400 $\beta-\mathrm{Glu}-\mathrm{U} / \mathrm{kg}$ reduced FCR equivalent to PC_1. Intestinal viscosity correlated with d1-21 FCR and inversely correlated with d1-21 live weight gain (LWG). When analyzed categorically, dietary viscosity inversely correlated with $\mathrm{d} 1-21 \mathrm{LWG}(P<0.05)$. This study demonstrates that $\mathrm{AC} 1$ can reduce intestinal viscosity and improve early FCR in birds fed high viscosity diets and that an in vitro viscosity can correlate to broiler performance. 


\section{DESCRIPTION OF PROBLEM}

The primary cereal grains used in diet formulations in the US poultry industry are corn and soybean meal [1-3]. However, sometimes other grains or agricultural by-products with variable levels of anti-nutritive factors (ANF) are used to decrease dietary costs. Corn distillers' dried grains with solubles (DDGS) are a by-product of ethanol production and contain low amounts of starch and higher levels of non-starch polysaccharides (NSP) relative to corn [4]. Other cereal grains, such as wheat, contain NSP at concentrations that could be detrimental to broiler performance [5]. The presence of NSP can lead to increased intestinal viscosity, reduced nutrient digestibility, increased feed conversion ratio (FCR), and decreased overall bird performance [1, 3, 6, 7]. Beta-glucan, a specific NSP found in both wheat and DDGS, is partially water soluble and contributes to the formation of a gel-like viscous layer within the gastrointestinal (GI) tract of the broiler [8]. Viscous digesta is known to reduce the rate of diffusion of feed substrates, digestive enzymes, and their products, thereby reducing the absorption of nutrients in the diet [9-11]. Betaglucans may also increase microflora growth, as well as wet, sticky excreta $[8,12,13]$.

To combat the negative effects associated with dietary NSP, poultry nutritionists have employed the use of carbohydrase enzymes, as poultry are not capable of adequately digesting these compounds [14-17]. Specifically, $\beta$-glucanase is a hydrolytic carbohydrase, targeting glycosidic bonds in barley, oat, or wheat based diets and has been shown to improve feed conversion efficiency, lower intestinal viscosity, and increase feed intake [18- 25].

Lowering ileal viscosity is a demonstrated mode of action for $\beta$-glucanase $[17,18,26]$. However, testing the efficacy of enzymes on reducing intestinal viscosity in feeding studies is time consuming and is associated with a high degree of variability. There are many factors that contribute to variability in broiler viscosity studies, including grain types and quality, substrate 
concentrations, NSP solubility, feed preparation and processing, and bird age. Viscosity test conditions may also vary in viscometer type and operating conditions, and the amount of substrate used $[9,18,26]$. Bedford and Classen [27] reported an in vitro dietary viscosity assay where the resulting data had a strong correlation to in vivo proximal $\left(\mathrm{R}^{2}=0.76, \mathrm{P}<0.001\right)$ and distal jejunal intestinal viscosity $\left(\mathrm{R}^{2}=0.66, \mathrm{P}<0.001\right)$. Based on these results, the authors concluded that the in vitro viscosity assay is reliable for predicting the in vivo viscosity and weights of birds fed corresponding diets [27]. Other researchers [28] compared in vitro dietary and in vivo intestinal viscosity with various xylanase supplementations and found weak but significant correlations when using either 0.05 or $0.1 \mathrm{M} \mathrm{HCl}$ in the pepsin digestion phase. These authors concluded that in vitro viscosity may also be used for predicting an in vivo intestinal response to xylanase treatments [28].

Traditionally, exogenous enzymes have been microbially expressed and are formulated into a granulated, coated, or liquid dietary ingredient. However, an alternative to these traditional enzyme products are recombinant enzymes produced in transgenic grain, which provides a significant economic production advantage [29-37]. In the current study, a recombinant carbohydrase was expressed in corn grain (AC1, Agrivida) using methods described before [20, 21, 38, 39]. Previous research with AC1 demonstrated heat tolerance during feed pelleting [20, 21] and reduced ileal viscosity of broilers fed 200 or $400 \mathrm{U} \beta$-Glucanase ( $\boldsymbol{\beta}$-Glu-U) of AC1 per $\mathrm{kg}$ of feed [20].

The objectives of the current study were to (1) test AC1 enzyme efficacy on dietary (in vitro) and intestinal (in vivo) viscosity and subsequent animal performance with a high NSP diet and (2) determine whether in vitro viscosity, in vivo viscosity and broiler performance are correlated. 


\section{MATERIALS AND METHODS}

\section{Diet Formulations}

Diets consisted of two positive controls (PC_1 and PC_2), each formulated with 3,050 $\mathrm{kcal} / \mathrm{kg}$ of metabolizable energy (ME; Table 1). The PC diets were formulated using ME and mineral concentrations reported in Agristat [40], and digestible amino acid concentrations based on recommendations by Tillman and Dozier [41]. The PC_1 diet was a typical corn-soybean meal based diet and PC_2 was a corn-soybean meal based diet with a $10 \%$ inclusion of wheat and a $10 \%$ inclusion of DDGS. The negative control (NC) was formulated with similar ingredients as PC_2 diet, except that the ME was reduced by $125 \mathrm{kcal} / \mathrm{kg}$ by decreasing soybean oil inclusion (Table 1). The NC diet was supplemented with AC1 to supply 50,100, 200, 400, or $600 \beta-\mathrm{Glu}-\mathrm{U} / \mathrm{kg}$ to make the other five dietary treatments. Wheat from three different sources [42-44] were acquired and tested for viscosity, and the wheat source with the highest analyzed viscosity was chosen to be included in the PC_2, NC and AC1 diets.

\section{Wheat sample digestion for viscosity measurement}

Duplicate samples of each wheat source were ground with both an air-assisted hammer mill with 5mm screen size and Wiley Mill with $1 \mathrm{~mm}$ screen size. After all wheat had been ground, digestion was simulated and viscosity was determined using methods described by Bedford and Classen $[27,45]$.

\section{Feed Manufacture and Diet Viscosity}

All feed was manufactured at the West Virginia University pilot feed mill. A total of $907.18 \mathrm{~kg}$ of feed was batched according to the NC diet formulation (Table 1). The NC diet was then split into 6 allotments of $136.08 \mathrm{~kg}$ each. One of the 6 allotments was kept as the NC diet, and the other five were mixed with $\mathrm{AC} 1$ corn meal at their respective target doses. For each enzyme 
diet, AC1 was premixed with a 3-kg sample of $\mathrm{NC}$ feed in a small paddle mixer prior to mixing with the remaining NC feed in a single-screw vertical mixer [47]. Both PC_1 and PC_2 treatments required $158.76 \mathrm{~kg}$ of feed per treatment. Wheat utilized in the PC_2, NC and AC1 diets was ground using a roller mill. All diets were fed in mash form and particle size was determined using a Ro-Tap Particle Size Analyzer [48] (Table 3). Complete feed samples for each treatment were collected post-enzyme addition for proximate analysis and $\beta$-glucanase activity (Table 3).

Samples from each diet were ground using a hammer mill and examined for viscosity in triplicate. Methodology of the pepsin-pancreatin digestion was similar to that used for wheat sample digestion as described above; however, to obtain an adequate amount of supernatant, the amount of the reagents/solutions utilized in the digestion series were doubled.

\section{Live Bird Performance}

A total of 960 1-day-old Hubbard x Ross 708 male chicks were obtained from a commercial hatchery [51]. On d1, the chicks were separated by weight class. Then, one bird from each weight class was selected and placed into a group of 10 total chicks, and the group was placed in 1 of 96 raised wire cages to create uniform, initial pen weights. One of the 8 diets was randomly assigned to each pen within a block. A block consisted of 8 adjacent cages; a total of 12 blocks were utilized.

Chicks were housed in raised wire cages in a cross-ventilated, negative-pressure room for $21 \mathrm{~d}$. Two identical rooms were utilized; each containing 48 cages, creating a total of 96 cages. Standard rearing conditions were utilized throughout the study [52]. The animal performance variables measured included: d1 starting pen weight and d7, 14 and 21 bird weights, bird feed intake (FI), live weight gain/bird (LWG), mortality corrected FCR and percent mortality. All animals were reared according to protocols approved by West Virginia University Animal Care and Use Committee. 


\section{In vivo Intestinal Digesta Collection and Viscosity Measurements}

On d14, four birds from each pen were euthanized via cervical dislocation. The entire digestive tract (beginning of duodenum to the ileal-cecal junction) was removed, and the digesta was squeezed out by hand into a $50 \mathrm{~mL}$ centrifuge tube. The digesta was then centrifuged, using methodologies described by Bedford and Classen $[1,53]$. To determine in-vivo intestinal viscosity, methodologies were similar to previous research [20,55-58], with measurements taken at 30s or 1 min and at two different centrifugal speeds: $10 \times g$ or $20 \times g$.

\section{AC1 Enzyme Activity Assay}

AC1 enzyme activity in transgenic maize grain or in manufactured feed was tested as described previously $[20,21]$.

\section{Statistical Analysis}

All data were analyzed in a randomized complete block design with the raised wire cage location within room determining block. The experimental unit was one pen containing 10 Hubbard x Ross 708 male chicks. The PROC GLM procedure of SAS [59] was used to analyze data by one-way ANOVA. Means were then further separated using Fisher's least significant difference (LSD) post hoc comparison when the ANOVA was significant $(P \leq 0.05)$. Correlations between replicated control treatments (PC_1, PC_2, and $\mathrm{NC})$ and the overall $\mathrm{AC} 1$ response (averaged by replicate, across all AC1 treatments) were determined using the PROC CORR procedure in SAS [59]. In addition, since in vitro dietary viscosity data was performed on feed obtained from a single batch of feed without replication of the manufacture process, these data were categorical by design and a second correlation was determined using these data and treatment mean results from live study metrics. Strength of correlation was determined using R-values and accompanying $P$ values to demonstrate the significance of correlation. 


\section{RESULTS AND DISCUSSION}

Wheat grown in different environments may have some level of variation in its nutritive and anti-nutritive values, therefore, broiler intestinal viscosity responses may differ when supplementing the diet with digestive enzymes. These variations are likely reflecting the differences in soluble NSP levels in wheat [60]. To ensure that increases in dietary viscosity were measurable in this study, the viscosity of three wheat varieties were examined before feed formulation. As demonstrated in Table 2, Source B had consistently higher viscosity compared to the other two sources; therefore, Source B wheat was chosen to be incorporated into the PC_2, NC and $\mathrm{AC} 1$ diets to test $\mathrm{AC} 1$ efficacy and intestinal viscosity response.

The in vitro, dietary viscosity results from the experimental treatment diets can be found

in Table 3. In vitro, dietary viscosity of the formulated feed was numerically higher in diets including wheat and DDGS such as PC_2 $(2.02 \mathrm{cP})$ and $\mathrm{NC}(1.87 \mathrm{cP})$, compared to a common corn-soybean meal based diet (PC_1; $1.81 \mathrm{cP})$. The authors hypothesize that the higher viscosity in PC_2 could be due to the combination of wheat, DDGS, and increased soybean oil inclusion (Table 1). Differences in particle size between treatments were not apparent (Table 3). AC1 enzyme activity recovered from each diet approximated the target dosage $\pm 43 \mathrm{U} / \mathrm{kg}$ shown in Table 3. In vitro, dietary viscosity was reduced with $\mathrm{AC} 1$ addition to the NC diet, in a step-wise manner, through $400 \beta$-Glu-U/kg. For example, AC1 inclusion at $50 \beta$-Glu-U/kg lowered dietary viscosity $(1.82 \mathrm{cP})$ similar to the level of PC_1. As AC1 enzyme dosages increased in the diets from 200 to $600 \beta-\mathrm{Glu}-\mathrm{U} / \mathrm{kg}$, the dietary viscosity was further reduced within the range of $1.66-$ $1.74 \mathrm{cP}$.

Table 4 shows the in vivo, intestinal viscosity response to AC1 treatments. Birds fed NC or PC_2 diets had the highest intestinal viscosity (3.06 and $3.08 \mathrm{cP}$, respectively) whereas birds 
fed PC_1 had significantly lower viscosity $(2.73 \mathrm{cP} ; P<0.05 ; 10 \mathrm{x}$ g for $30 \mathrm{~s})$. All AC1 treatments had statistically equivalent intestinal viscosity as PC_1 $(P>0.05)$. The treatments containing 100 or $600 \beta-G l u-U / k g$ AC1 had significantly lower intestinal viscosity than the NC and PC_2 treatments $(P<0.05)$. These data demonstrate AC1 efficacy in lowering digesta viscosity; although trends toward decreased viscosity associated with the enzyme titration were not apparent. Perhaps variability of the viscosity assay and live bird model contributed to these results. In general, these results are in agreement with previously published data that demonstrated the ability of carbohydrase enzymes to reduce digesta viscosity $[11,20,26,61-65]$.

Broiler performance metrics are exhibited in Table 5. The addition of AC1 (50-400 $\beta$-Glu$\mathrm{U} / \mathrm{kg})$ to the reduced ME, wheat and DDGS supplemented diet resulted in equivalent $(P>0.05)$ d1-7 FCR as the PC_1 (higher energy, corn-soybean only). From d 1-13, FCR was equivalent ( $P$ $>0.05$ ) between birds fed $50 \beta-\mathrm{Glu}-\mathrm{U} / \mathrm{kg}$ and the PC_1 diets. However, no AC1 dose response was observed for any growth performance variable. As reported by Steenfeldt and co-authors [65], the response to exogenous dietary enzyme addition was most notable during the first few weeks of life, which was similarly observed in the current study. Overall, from d 1-21, birds fed the cornsoybean only diet (PC_1) had the lowest FCR compared to all wheat and DDGS supplemented diets $(P<0.001)$. Unlike previous research $[20,36]$ that demonstrated an increase in broiler weight when $\mathrm{AC} 1$ was fed for 14 or $18 \mathrm{~d}$, no difference in LWG $(P>0.05)$ was observed among treatments in the current study.

Using replicated pen data from the control treatments (PC_1, NC, and PC_2) and averages of all $\mathrm{AC} 1$ treatments (averaged by replicate; $\mathrm{n}=12$ ) demonstrated that in vivo, intestinal viscosity inversely correlated $(\mathrm{r}=-0.387 ; P<0.01)$ with $\mathrm{d} 1-21 \mathrm{LWG}$ and correlated $(\mathrm{r}=0.326 ; P<0.05)$ with d1-21 FCR (Table 6). The intestinal viscosity from AC1 treatments were averaged across 
doses to decrease variability associated with individual $\mathrm{AC} 1$ treatments prior to correlation analysis because the AC1 response observed was not dose dependent for growth performance. While the authors appreciate that use of categorical data decreases the power of correlation analysis, in vitro, dietary viscosity data was performed on feed obtained from a single batch of feed without replication of the manufacture process. These data were considered categorical, therefore the in vivo study metrics were averaged across replicate pens within each treatment for the second correlation determination (Table 7). The categorical data demonstrated in vitro dietary and in vivo intestinal viscosity inversely correlated $(P<0.05 ; \mathrm{r}=-0.725$ and -0.387 , respectively) with d1-21 LWG. There was a tendency for in vitro dietary viscosity to correlate $(r=0.604)$ with in vivo intestinal viscosity $(P=0.11)$ and inversely correlate $(\mathrm{r}=-0.611)$ with $\mathrm{d} 1-13 \mathrm{FCR}(P=$ $0.11)$.

In previous research [27, 28], feed assays have been explored as a more rapid and inexpensive, alternative method to live bird studies to assess viscosity differences among feed ingredients and efficacy of carbohydrases. Bedford and Classen [27] reported that dietary viscosity from two-stage simulated GI digesta can be used to predict an intestinal response to enzymes in rye-based diets. Those authors examined several amounts of substrate (complete diet) and incubation times to determine the optimum conditions for this procedure. Those authors found that the logarithmic values of the viscosities in the experimental diets correlated well with intestinal viscosity measurements and that in vitro, dietary viscosity was able to predict final body weights of the birds. A similar response was observed in the current study, as demonstrated by dietary and intestinal viscosity correlating (inversely) with d1-21 LWG. Murphy et al. [28] examined eighteen xylanases and detected a weak but significant relationship between in vitro and in vivo viscosity data when testing xylanases on wheat-based diets, but found no relationship between LWG and 
jejunal digesta viscosity. However, unlike Bedford and Classen [27], these authors examined xylanase using wheat, alone, instead of a complete diet.

In conclusion, the addition of a highly viscous wheat variety together with DDGS increased dietary and intestinal viscosity providing a model to examine the response of exogenous enzyme supplementation. In this study, $\mathrm{AC} 1$ was able to decrease intestinal viscosity, comparable to that of the corn-soybean meal control treatment (PC_1). As demonstrated with this model, AC1 may be most efficacious to feed during early development, as d1-7 FCR was improved with AC1 inclusion between 50 and $400 \beta$-Glu-U/kg. The inclusion of AC1 at $50 \beta-G l u-U / k g$ also produced d1-13 FCR comparable to that of PC_1. Utilizing control and averaged AC1 treatments, correlations were observed between intestinal viscosity and growth performance. Analysis of all treatments categorically demonstrated a correlation between in vitro dietary viscosity and d1-21 LWG $(P<0.05)$.

\section{CONCLUSIONS AND APPLICATIONS}

1. Descriptive diet and replicated intestinal viscosity numerically and statistically increased respectively when $10 \%$ wheat and $10 \%$ DDGS was supplemented to corn-soybean meal based diets. Inclusion of AC1 to the wheat-DDGS supplemented diet produced viscosity levels comparable to the corn-soybean meal based diet.

2. Early animal performance corresponded to viscosity response, in that addition of wheat and DDGS increase d1-7 FCR and supplementing AC1 from 50 to $400 \beta$-Glu-U/kg to this higher viscosity diet improved FCR equivalent to the birds fed the corn-soybean meal only diet.

3. Intestinal viscosity correlated to d1-21 FCR and LWG (inversely) when comparing the control (PC_1, NC, and PC_2) and averaged AC1 treatments. 
4. Analysis of all treatments categorically demonstrated a correlation between in vitro dietary viscosity and d1-21 LWG. 


\section{REFERENCES AND NOTES}

1. Bedford, M. R., and H. L. Classen. 1992. Reduction of intestinal viscosity through manipulation of dietary rye and pentosanase concentation is effected through changes in the carbohydrate composition of the intestinal aqueous phase and results in improved growth rate and food conversion efficiency of broiler chicks. J. Nutr. 122:560-569.

2. Gracia, M. I., M. J. Aranibar, R. Lázaro, P. Medel, and G. G. Mateos. 2003. Asupplementation of broiler diets based on corn. Poult. Sci. 82:436-442.

3. Meng, X., and B. A. Slominski. 2005. Nutritive values of corn, soybean meal, canola meal, and peas for broiler chickens as affected by a multicarbohydrase preparation of cell wall degrading enzymes. Poult. Sci. 84:1242-1251.

4. Min, Y. N., F. Yan, F. Z. Liu, C. Coto, and P. W. Waldroup. 2009. Effect of various dietary enzymes on energy digestibility of diets high in distillers dried grains with solubles for broilers. J. Appl. Poult. Res. 18:734-740.

5. Annison, G., and M. Choct. 1991. Anti-nutritive activities of cereal non-starch polysaccharides in broiler diets and strategies minimizing their effects. World's Poult. Sci. J. 47:232-242.

6. Bedford, M. R., and A. J. Morgan. 1996. The use of enzymes in poultry diets. World's Poult. Sci. J. 52:61-68.

7. Lázaro, R., M. Gracia, M. J. Aranibar, and G. G. Mateos. 2003. Effect of enzyme addition to wheat-, barley- and rye-based diets on nutrient digestibility and performance of laying hens. Br. Poult. Sci. 84:37-47.

8. Choct, M., and G. Annison. 1992. Anti-nutritive effect of wheat pentosans in broiler chickens: roles of viscosity and gut microflora. Br. Poult. Sci. 33:821-834.

9. Bedford, M. R., 1995. The use of enzymes in poultry diets. Pages 18-22 in: Proc. WPSA UK Branch Spring Meeting. Scarborough, UK.

10. Fengler, A. I., and R. R. Marquardt, 1988. Water-soluble pentosans from rye. II. Effects on rate of dialysis and on the retention of nutrients by the chick. Cereal Chem. 65: 298302.

11. Bedford, M. R., and H. L. Classen. 1992. Reduction of intestinal viscosity in barleyfed broilers by $\beta$-glucanase: Site of action and effect on bird performance. Anim. Production. 54:88.

12. Choct, M. 1997. Feed non-starch polysaccharides: chemical structures and nutritional significance. Feed Milling International. June. 13-26.

13. Henry, R. J. 1987. Pentosan and $(1 \rightarrow 3)$, $(1 \rightarrow 4)$ - $\beta$-Glucan concentrations in endosperm and wholegrain of wheat, barley, oats, and rye. J. of Cereal Science. 6:253-258.

14. Khattak, F. M., T. N. Pasha, Z. Hayat, and A. Mahmud. 2006. Enzymes in Poultry Nutrition. J. Anim. Pl. Sci. 16:1-2.

15. Ravindran, V. 2013. Feed enzymes: The science, practice, and metabolic realities. J. Appl. Poult. Res. 22:628-636.

16. Bedford, M. R. 2000. Exogenous enzymes in monogastric nutrition - their current value and future benefits. Anim. Feed Sci. and Tech. 86:1-13.

17. Bedford M.R. \& Partridge G.G (2010) Enzymes in farm animal nutrition, $2^{\text {nd }}$ Edition

18. Almirall, M., and E. Esteve-Garcia. 1994. Rate of passage of barley diets with chromium oxide: influence of age and poultry strain and effect of $\beta$-glucanase supplementation. Poult. Sci. 73:1433-1440. 
19. Almirall, M., Francesch, M., Perez-Vendrell, A. M., Brufau, J. and E. Esteve-Garcia. 1995. The differences in intestinal viscosity produced by barley and $\beta$-glucanase alter digesta enzyme activities and ileal nutrient digestibilities more in broiler chicks than in cocks. Journal of Nutrition 125:947-955.

20. Ayres, V., H. L. Baldwin, X. Li, H. Xu, R. M. Raab, J. W. Boney, J. N. Broomhead, and J. S. Moritz. 2018. The effect of corn-expressed carbohydrase on performance and digesta viscosity of broilers fed a high non-starch polysaccharide diet. J. Appl. Poult. Res. 27:499-506.

21. Jasek, A. T., X. Li, H. Xu, R. M. Raab, J. N. Broomhead, and J. T. Lee. 2018. Effects of increasing concentrations of maize-expressed non-starch carbohydrase enzyme on broiler performance and ileal nutrient digestibility. Int. J. Poult. Sci. 17:543-551.

22. Von Wettstein, D., J. Warner and C. G. Kannangara . 2003. Supplements of transgenic malt or grain containing $(1,3-1,4)$-beta-glucanase increase the nutritive value of barleybased broiler diets to that of maize. Br. Poult. Sci., 44:438-49.

23. Józefiak, D., A., Rutkowski, B. B., Jensen and R. M., Engberg. 2006. The effect of $\beta$ glucanase supplementation of barley- and oat-based diets on growth performance and fermentation in broiler chicken $\mathrm{m}$ tract. Br. Poult. Sci., 4: 57-64.

24. Smulikowska, S. 1998 Relationship between the stage of digestive tract development in chicks and the effect of viscosity reducing enzymes on fat digestion. J. Anim. Feed Sci. 7:125-134.

25. Brenes, A., W. Guenter, R. R. Marquardt, and B. A. Rotter. 1993. Effect of $\beta$ glucanase/pentosanase enzyme supplementation on the performance of chickens and laying hens fed wheat, barley, naked oats and rye diets. Can. J. Anim. Sci. 73:941-951.

26. Choct, M., R. J. Huges, R. P. Trimble, K. Angkanaporn, G. Annison. 1995. Non-starch polysaccharide-degrading enzymes increase the performance of broiler chickens fed wheat and low apparent metabolizble energy. J. Nut. 125:485-492.

27. Bedford, M. R., and H. L. Classen. 1993. An In vitro Assay for Prediction of Broiler Intestinal Viscosity and Growth When Fed Rye-Based Diets in the Presence of Exogenous Enzymes. Poult. Sci. 72:137-143.

28. Murphy, T. C., J. K. Mccrachen, M. E. E. McCann, J. George and M.R. Bedford. 2009. Broiler performance and in vivo viscosity as influenced by a range of xylanases, varying in ability to effect wheat in vitro viscosity. Br. Poult. Sci. 50:716-724.

29. Pen, J., T. C. Verwoerd, P. A. van Paridon, R. F. Beudeker, P. J. M. van den Elzen, K. Geerse, J. D. van der Klis, H. A. J. Versteegh, A. J. J. van Ooyen, and A. Hoekema. 1993. Phytase-containing transgenic seeds as a novel feed additive for improved phosphorus utilization. Nat. Biotechnol. 11:811-814.

30. Nyannor, E. K. D., and O. Adeola. 2008. Corn Expressing an Escherichia Coli-Derived Phytase Gene: Comparative Evaluation Study in Broiler Chicks. Poult. Sci. 87:20152022.

31. Nyannor, E. K. D., M. R. Bedford, and O. Adeola. 2009. Corn expressing an Escherichia coli-derived phytase gene: Residual phytase activity and microstructure of digesta in broiler chicks. Poult. Sci. 88:1413-1420. 
32. Gao, C. Q., Q. G. Ma, C. Ji, X. G. Luo, H. F. Tang, and Y. M. Wei. 2012. Evaluation of the compositional and nutritional values of phytase transgenic corn to conventional corn in roosters. Poult. Sci. 91:1142-1148.

33. Gao, C. Q., C. Ji, L. H. Zhao, J. Y. Zhang, and Q. G. Ma. 2013. Phytase transgenic corn in nutrition of laying hens: Residual phytase activity and phytate phosphorus content in the gastrointestinal tract. Poult. Sci. 92: 2923-2929.

34. Denbow, D. M., E. A. Grabau, G. H. Lacy, E. T. Kornegay, D. R. Russell, and P. F. Umbeck. 1998. Soybeans Transformed with a Fungal Phytase Gene Improve Phosphorus Availability for Broilers. Poult. Sci. 79:878-881.

35. Broomhead, J. N., P. A. Lessard, R. M. Raab, M. B. Lanahan, and J. J. Chewning. 2017. A 41-d feeding trial was conducted to determine the efficacy of a corn-expressed phytase (CEP; Grainzyme; Agrivida) on the live performance, bone characteristics, and phosphorus digestibility of nursery pigs. J. Anim. Sci. 95 (Suppl. 2):118-119.

36. Johnson, C., A. Jasek, J. Broomhead, X. Li, and J. Lee. 2017. Effects of increasing concentrations of corn-expressed non-starch polysaccharide enzyme on broiler performance and ileal nutrient digestibility. Poult. Sci. 96 (E-Suppl. 1):160.

37. Kim, E. J., M. E. Persia, J. Broomhead, X. Li, P. Lessard, and M. Lanahan. 2016. Nitrogen-corrected apparent metabolizable energy of an exogenous carbohydrase added to diets formulated with low-fat distillers dried grains with solubles (LF-DDGS) from 0 to $28 \mathrm{~d}$ in broilers. Poult. Sci. 95 (E-Suppl. 1):60.

38. Negrotto, D., M. Jolley, S. R. W. A. Beer, A. R. Wenck, and G. Hansen. 2000. The use of phosphomannose-isomerase as a selectable marker to recover transgenic maize plants (Zea mays L.) via Agrobacterium transformation. Plant cell reports, 19(8):798803.

39. Raab, R.M. O. Bougri, X. Li. 2016. United States Patent US2016/032418.

40. Agri Stats Inc., Fort Wayne, IN, 46825.

41. Tillman, P. B. and W.A. Dozier. 2013. Current Amino Acid Considerations for Broilers: Requirements, Ratios, Economics

42. Sam's Agway, Oakland, MD

43. Southern States, Morgantown, WV

44. Valley Point Farmers Feed, Albright, WV.

45. To synthesize digestion, a $0.1 \mathrm{~N} \mathrm{HCl}$ solution $(0.9 \mathrm{~mL})$ containing 2,000 $\mathrm{U}$ pepsin $/ \mathrm{mg}$ was added to $0.6 \mathrm{~g}$ of wheat. The samples were incubated at $40^{\circ} \mathrm{C}$ for 45 min with occasional vortexing. To simulate pancreatic digestion, $0.3 \mathrm{~mL}$ of a $1 M \mathrm{NaCO}_{3}$ solution containing $2 \mathrm{mg} / \mathrm{mL}$ pancreatin ( $8 \times$ USP) was added. The samples were then allowed to continue incubating at $40^{\circ} \mathrm{C}$ for 120 min with occasional vortexing. Next, all contents were transferred into microcentrifuge tubes and centrifuged at $12,700 \mathrm{x} \mathrm{g}$ for $2 \mathrm{~min}$. About $1 \mathrm{~mL}$ supernatant was transferred into a second microcentrifuge tube and placed in a $25^{\circ} \mathrm{C}$ water bath [46] for approximately 10 minutes. Afterwards, 0.5 $\mathrm{mL}$ digesta supernatant was subjected to viscosity measurement.

46. TC-602 Refrigerated Bath, Brookfield Engineering Laboratories Inc., Middleboro, MA.

47. Vertical mixer, Avery Weigh-Tronix, Fairmont, MN.

48. Particle size of the crumbled feed was determined using a Ro-Tap Particle Size Analyzer [49]. One hundred grams of each crumbled diet was placed in a dust-tight enclosed series of stacked ASTM screens affixed to the Ro-Tap Particle Size Analyzer 
and shaken for 10 minutes. The screens were then separated and weighed. Particle size was then determined by subtracting the weight of the screen from the final weight of the screen and sample after shaking. The mean geometric particle size and log normal geometric standard deviation were calculated as described by McEllhiney [50].

49. Ro-Tap Particle Size Analyzer, W.S. Tyler, Mentor, OH.

50. McEllhiney, R.R. 1994. Feed Manufacturing Industry.

51. Longenecker's Hatchery.

52. Room temperature for the 1-day-old chicks was set at $32^{\circ} \mathrm{C}$, and gradually decreased to $29^{\circ} \mathrm{C}$ for the second week and $26^{\circ} \mathrm{C}$ for the third week of the study, to create optimal rearing conditions. Feed was placed in external feed troughs and water was supplied through a nipple drinker system; both feed and water were provided for ad libitum consumption. Lighting was manipulated through grow-out to ensure that birds had a full GI tract when sampled on d14. From d1 to 6, birds were exposed to $24 \mathrm{~h}$ light, and after $\mathrm{d} 6$, the hours of light were decreased gradually until 6h dark was reach on $\mathrm{d} 20$ and 21.

53. Digesta was centrifuged [54] at $12,700 \times \mathrm{g}$ for 5 minutes at $4^{\circ} \mathrm{C}$ [1]. Subsequently, 1 $\mathrm{mL}$ supernatant from each digesta sample was transferred into a microcentrifuge tube and placed in a $25^{\circ} \mathrm{C}$ water bath [TC 602] for approximately 10 minutes before viscosity measurements were obtained.

54. Sorvall Evolution RC Centrifuge, Asheville, NC.

55. Brookfield LVDV-II+Pro Viscometer, Brookfield Engineering Laboratories Inc., Middleboro, MA.

56. Lee, J. T., C. A. Bailey, and A. L. Cartwright. 2003. Guar meal germ and hull fractions differently affect growth performance and intestinal viscosity of broiler chickens. Poult. Sci. 82:1589-1595.

57. Lamp, A. E., A. M. Evans, J. S. Moritz. 2015. The effects of pelleting and glucanase supplementation in hulled barley based diets on feed manufacture, broiler performance, and digesta viscosity. J. Appl. Poult. Res. 24:295-303.

58. About $0.5 \mathrm{~mL}$ digesta supernatant of wheat or feed, or intestinal digesta was placed in a Brookfield cone and plate viscometer [52] with a CPE-40 cone and a CPE-44Y cup to determine viscosity. Measurements were taken at $30 \mathrm{~s}$ or $1 \mathrm{~min}$ and at two different centrifugal speeds: $10 \mathrm{x} g$ or $20 \mathrm{x} g$.

59. SAS Institute. 2017. The SAS System for Windows 2017. Release 9.4. SAS Inst. Inc., Cary, NC.

60. Scott, T. A., F. G., Silversides, H. L., Classen, M. L., Swift and M. R., Bedford. 1998. Effect of cultivar and environment on the feeding value of Western Canadian wheat and barley samples with and without enzyme supplementation. Can. J. Anim. Sci. 78(4):649-656.

61. Petterson, D. and P. Åman. 1989. Enzyme supplementation of a poultry diet containing rye and wheat. Br. J. Nutr. 62:139-149.

62. Friesen, O. D., W. Guenter, R. R. Marquardt, B. A. Rotter. 1992. The effect of enzyme supplementation on the apparent metabolizable energy and nutrient digestiblities of wheat, barley, oats, and rye for the young broiler chick. Poult. Sci. 71:1710-1721.

63. Marquardt, R. R., D. Boros, W. Guenter, G. Crow. 1994. The nutritive value of barley, rye, wheat and corn for young chicks as affected by use of a Trichoderma reesei enzyme preparation. Anim. Feed Sci. Technol. 45:363-378. 
64. Veldman, A., and H. A. Vahl. 1994. Xylanase in broiler diets with differences in characteristics and content of wheat. Br. Poult. Sci. 35:537-550.

65. Steenfeldt, S., A. Müllertz, and J. Fris Jensen. 1998. Enzyme supplementation of wheat-based diets for broilers 1 . Effect on growth performance and intestinal viscosity. Animal Feed Sci. Technol. 75:27-43. 
Table 1. Diet Formulations fed for $21 \mathrm{~d}$ trial

\begin{tabular}{lccc}
\hline & \multicolumn{3}{c}{ Inclusion (\%) } \\
\hline Ingredients & PC_1: Corn-SBM & $\begin{array}{c}\text { PC_2: Wheat and } \\
\text { DDGS }^{2}\end{array}$ & Negative Control $^{3}$ \\
\hline Corn & 53.02 & 37.83 & 40.24 \\
Soybean Meal (48\% CP) & 37.83 & 33.08 & 32.77 \\
Wheat & -- & 10 & 10 \\
DDGS & -- & 10 & 10 \\
Dicalcium Phosphate & 1.79 & 1.71 & 1.70 \\
Limestone & 1.32 & 1.36 & 1.37 \\
L-Lysine HCL & 0.13 & 0.22 & 0.22 \\
DL-Methionine & 0.49 & 0.48 & 0.47 \\
Soybean Oil & 4.44 & 4.44 & 2.35 \\
Vit/Min Premix & 0.25 & 0.25 \\
L-Threonine & 0.30 & 0.31 & 0.31 \\
White Salt & 0.33 & 0.22 & 0.22 \\
Sodium Bicarbonate & 0.10 & 0.10 & 0.10 \\
\hline & & Calculated Nutrients $^{4}$ & 2,925 \\
ME (kcal/kg) & 3,050 & 3,050 & 22.86 \\
Crude Protein (\%) & 22.25 & 22.86 & 1.01 \\
Calcium (\%) & 1.01 & 1.01 & 0.46 \\
Available Phosphorus (\%) & 0.46 & 0.46 & 0.17 \\
Sodium (\%) & 0.17 & 0.17 & 1.20 \\
Dig Lysine (\%) & 1.20 & 1.20 & 0.77 \\
Dig Methionine (\%) & 0.79 & 0.78 & 1.08 \\
Dig Methionine and Cysteine (\%) & 1.08 & 1.09 & 1.01 \\
Dig Threonine (\%) & 1.01 & 1.01 & 0.24 \\
Dig Tryptophan (\%) & 0.24 & 0.24 & 21.65 \\
\hline & & Analyzed Nutrients & \\
\hline Crude Protein (\%) & 22.9 & 21.4 & \\
Crude Fat (\%) & 5.34 & 6.37 & \\
\hline
\end{tabular}

${ }^{1}$ Corn and soybean meal positive control diet.

${ }^{2}$ Corn and soybean meal based positive control with inclusion of $10 \%$ wheat and $10 \%$ DDGS.

${ }^{3}$ Similar to PC_2 but with ME reduced by $125 \mathrm{kcal} / \mathrm{kg}$; corn-expressed carbohydrase replaced equal amount of corn within this dietary formulation.

${ }^{4}$ Metabolizable Energy and Available Phosphorus were based on Agristat values as suggested by M. Donohue. 2013. The Challenges in Feeding Broilers in Times of High and Volatile Feed Ingredient Costs: How to Cover the Costs?. 2013 Mid-Atlantic Nutrition Conference proceedings. Digestible amino acids were based on the digestible lysine value (1.2\%) suggested by P. B. Tillman and W.A. Dozier. 2013. Current Amino Acid Considerations for Broilers: Requirements, Ratios, Economics. www.thepoultryfederation.com for $8-14$ day broilers. Digestible amino acid to digestible lysine ratios followed further recommendations of this communication (minimum of 0.54 methionine, 1.02 TSAA, 0.90 threonine, 0.21 tryptophan.

${ }^{5}$ Supplied per kg of diet: manganese, $0.02 \%$; zinc $0.02 \%$; iron, $0.01 \%$; copper, $0.0025 \%$; iodine, $0.0003 \%$; selenium, $0.00003 \%$; folic acid, $0.69 \mathrm{mg}$; choline, 386mg' riboflavin, $6.61 \mathrm{mg}$; biotin, $0.03 \mathrm{mg}$; vitamin B6, $1.38 \mathrm{mg}$; niacin, $27.56 \mathrm{mg}$; pantothenic acid, $6.61 \mathrm{mg}$; thiamine, $2.20 \mathrm{mg}$; manadione, $0.83 \mathrm{mg}$; vitamin B12, $0.01 \mathrm{mg}$; vitamin E, 16.53 IU; vitamin D3, 2133 ICU; vitamin A, 7716 IU. 
Table 2. Viscosity of three wheat sources analyzed prior to diet formulation ${ }^{1}$

\begin{tabular}{|c|c|c|c|c|c|}
\hline \multirow{2}{*}{ Wheat Source } & \multirow{2}{*}{ Mill used to Grind } & \multicolumn{4}{|c|}{ Viscosity (cP) at different speeds and times } \\
\hline & & $10 \times \mathrm{g} ; 30 \mathrm{~s}$ & $10 \times \mathrm{g} ; 60 \mathrm{~s}$ & $20 \times g ; 30 s$ & $20 \times g ; 60 s$ \\
\hline \multirow{2}{*}{ A } & Hammer mill & 2.79 & 2.67 & 2.82 & 2.76 \\
\hline & Wiley mill & 3.46 & 3.52 & 3.89 & 3.83 \\
\hline \multirow{2}{*}{$\mathrm{B}$} & Hammer mill & 3.20 & 3.23 & 3.33 & 3.26 \\
\hline & Wiley mill & 4.02 & 4.08 & 4.36 & 4.32 \\
\hline \multirow{2}{*}{$\mathrm{C}$} & Hammer mill & 3.01 & 3.04 & 3.46 & 3.38 \\
\hline & Wiley mill & 4.22 & 4.00 & 3.69 & 3.64 \\
\hline
\end{tabular}

${ }^{1}$ Samples were examined in duplicate from three separate suppliers to determine which wheat would provide the greatest viscosity challenge within the gastrointestinal tracts of the broilers. 
Table 3. Particle size, glucanase activity, and dietary (in vitro) viscosity in the complete diets

\begin{tabular}{|c|c|c|c|}
\hline Diet Formulation & Particle Size $^{5}$ (microns) & $\begin{array}{l}\text { Analyzed Glucanase Activity } \\
\qquad(\beta-\mathrm{Glu}-\mathrm{U} / \mathrm{kg})\end{array}$ & $\begin{array}{l}\text { In vitro Viscosity } \\
\text { (cP; } 10 \mathrm{x} \text { g for } 30 \mathrm{~s})\end{array}$ \\
\hline PC_1: Corn-SBM ${ }^{1}$ & $874.68 \pm 2.13$ & --- & 1.81 \\
\hline PC_2: Wheat and DDGS ${ }^{2}$ & $900.70 \pm 2.01$ & 0.08 & 2.02 \\
\hline Negative Control $(\mathrm{NC})^{3}$ & $888.11 \pm 2.05$ & --- & 1.87 \\
\hline $\mathrm{NC}+50 \beta-\mathrm{Glu}-\mathrm{U} / \mathrm{kg}^{4}$ & $908.01 \pm 2.05$ & 27.96 & 1.82 \\
\hline $\mathrm{NC}+100 \beta-\mathrm{Glu}-\mathrm{U} / \mathrm{kg}$ & $922.38 \pm 2.09$ & 72.96 & 1.83 \\
\hline $\mathrm{NC}+200 \beta-\mathrm{Glu}-\mathrm{U} / \mathrm{kg}$ & $906.90 \pm 2.10$ & 157.41 & 1.74 \\
\hline $\mathrm{NC}+400 \beta-\mathrm{Glu}-\mathrm{U} / \mathrm{kg}$ & $887.11 \pm 2.08$ & 392.49 & 1.66 \\
\hline $\mathrm{NC}+600 \beta-\mathrm{Glu}-\mathrm{U} / \mathrm{kg}$ & $878.64 \pm 2.02$ & 599.48 & 1.72 \\
\hline
\end{tabular}

${ }^{1}$ Corn and soybean meal positive control diet.

${ }^{2}$ Corn and soybean meal based positive control with inclusion of $10 \%$ wheat and $10 \%$ DDGS.

${ }^{3}$ Similar to PC_2 but with ME reduced by $125 \mathrm{kcal} / \mathrm{kg}$.

${ }^{4}$ Provided by corn-expressed carbohydrase.

${ }^{5}$ Particle size determined with a Ro-Tap particle size analyzer model RX-29 Type 110V 60H2.

$\beta$-Glu-U/kg $=\beta$-Glucanase units $/ \mathrm{kg}$ of feed 
Table 4. D14 digesta viscosity of broilers fed diets with or without AC1 enzyme inclusion

\begin{tabular}{|c|c|c|c|c|}
\hline \multirow{3}{*}{ Diet Formulation } & \multicolumn{4}{|c|}{ Digesta Viscosity (cP) } \\
\hline & \multicolumn{2}{|c|}{$10 \mathrm{Xg}$} & \multicolumn{2}{|c|}{$20 \mathrm{Xg}$} \\
\hline & $30 \mathrm{sec}$ & $1 \mathrm{~min}$ & $30 \mathrm{sec}$ & $1 \mathrm{~min}$ \\
\hline PC_1: Corn-SBM ${ }^{1}$ & $2.73^{c}$ & 2.72 & 2.85 & 2.80 \\
\hline PC_2: Wheat and DDGS ${ }^{2}$ & $3.08^{\mathrm{a}}$ & 3.13 & 3.18 & 3.15 \\
\hline Negative Control (NC) ${ }^{3}$ & $3.06^{\mathrm{ab}}$ & 3.18 & 3.03 & 3.00 \\
\hline $\mathrm{NC}+50 \beta-\mathrm{Glu}-\mathrm{U} / \mathrm{kg}^{4}$ & $2.89^{\mathrm{abc}}$ & 3.03 & 2.93 & 3.02 \\
\hline $\mathrm{NC}+100 \beta-$ Glu-U/kg & $2.64^{\mathrm{c}}$ & 2.96 & 3.03 & 2.93 \\
\hline $\mathrm{NC}+200 \beta-$ Glu-U/kg & $2.91^{\mathrm{abc}}$ & 3.02 & 2.96 & 2.93 \\
\hline $\mathrm{NC}+400 \beta-$ Glu-U/kg & $2.81^{\mathrm{bc}}$ & 2.87 & 2.87 & 2.83 \\
\hline $\mathrm{NC}+600 \beta-\mathrm{Glu}-\mathrm{U} / \mathrm{kg}$ & $2.70^{\mathrm{c}}$ & 2.82 & 2.86 & 2.81 \\
\hline Treatment P-value & 0.0259 & 0.2963 & 0.1485 & 0.2313 \\
\hline Treatment SEM & 0.1007 & 0.1373 & 0.0932 & 0.1173 \\
\hline Fisher's LSD ${ }^{5}$ & 0.2774 & --- & --- & --- \\
\hline
\end{tabular}

${ }^{1}$ Corn and soybean meal positive control diet.

${ }^{2}$ Corn and soybean meal based positive control with inclusion of $10 \%$ wheat and $10 \%$ DDGS.

${ }^{3}$ Similar to PC_2 but with ME reduced by $125 \mathrm{kcal} / \mathrm{kg}$.

${ }^{4}$ Provided by corn-expressed carbohydrase.

${ }^{5}$ Fisher's least significant difference multiple comparison test (a, b, c).

${ }^{\mathrm{a}-\mathrm{c}}$ Means with superscripts without a common letter differ significantly $(\mathrm{P}<0.05)$.

$\mathrm{AC} 1$ = Corn-expressed carbohydrase; $\beta$-Glu-U/kg $=\beta$-Glucanase units $/ \mathrm{kg}$ of feed 
Table 5. Growth performance of broilers when fed diets with or without AC1 enzyme inclusion

\begin{tabular}{|c|c|c|c|c|c|c|c|c|c|}
\hline \multirow[t]{2}{*}{ Diet Formulation } & \multicolumn{3}{|c|}{ Days 1-7 } & \multicolumn{3}{|c|}{ Days 1-13 } & \multicolumn{3}{|c|}{ Days 1-21 } \\
\hline & $\begin{array}{c}\text { Bird FI } \\
(\mathrm{kg})\end{array}$ & $\begin{array}{c}\text { Bird } \\
\text { LWG } \\
(\mathrm{kg})\end{array}$ & $\begin{array}{c}\text { FCR } \\
(\mathrm{kg} / \mathrm{kg})\end{array}$ & $\begin{array}{c}\text { Bird FI } \\
(\mathrm{kg})\end{array}$ & $\begin{array}{c}\text { Bird } \\
\text { LWG } \\
(\mathrm{kg})\end{array}$ & $\begin{array}{c}\text { FCR } \\
(\mathrm{kg} / \mathrm{kg})\end{array}$ & $\begin{array}{c}\text { Bird FI } \\
(\mathrm{kg})\end{array}$ & $\begin{array}{l}\text { Bird } \\
\text { LWG } \\
(\mathrm{kg})\end{array}$ & $\begin{array}{c}\text { FCR } \\
(\mathrm{kg} / \mathrm{kg})\end{array}$ \\
\hline PC_1: Corn-SBM ${ }^{1}$ & 0.093 & 0.082 & $1.15^{\mathrm{c}}$ & $0.367^{\mathrm{c}}$ & 0.261 & $1.41^{\mathrm{d}}$ & 3.78 & 0.744 & $1.29^{\mathrm{b}}$ \\
\hline PC_2: Wheat and DDGS ${ }^{2}$ & 0.097 & 0.080 & $1.22^{\mathrm{a}}$ & $0.381^{\mathrm{bc}}$ & 0.251 & $1.51^{\mathrm{a}}$ & 3.58 & 0.705 & $1.39^{\mathrm{a}}$ \\
\hline Negative Control (NC) ${ }^{3}$ & 0.099 & 0.082 & $1.20^{\mathrm{ab}}$ & $0.387^{\mathrm{ab}}$ & 0.263 & $1.46^{\mathrm{abc}}$ & 3.84 & 0.731 & $1.37^{\mathrm{a}}$ \\
\hline $\mathrm{NC}+50 \beta-\mathrm{Glu}-\mathrm{U} / \mathrm{kg}^{4}$ & 0.096 & 0.082 & $1.18^{\mathrm{abc}}$ & $0.380^{\mathrm{bc}}$ & 0.260 & $1.45^{\mathrm{cd}}$ & 3.90 & 0.732 & $1.36^{\mathrm{a}}$ \\
\hline $\mathrm{NC}+100 \beta-\mathrm{Glu}-\mathrm{U} / \mathrm{kg}$ & 0.101 & 0.087 & $1.16^{\mathrm{bc}}$ & $0.389^{\mathrm{ab}}$ & 0.266 & $1.46^{\mathrm{bc}}$ & 3.93 & 0.731 & $1.38^{\mathrm{a}}$ \\
\hline $\mathrm{NC}+200 \beta-\mathrm{Glu}-\mathrm{U} / \mathrm{kg}$ & 0.97 & 0.084 & $1.18^{\mathrm{bc}}$ & $0.394^{\mathrm{ab}}$ & 0.263 & $1.50^{\mathrm{ab}}$ & 3.84 & 0.730 & $1.38^{\mathrm{a}}$ \\
\hline $\mathrm{NC}+400 \beta-\mathrm{Glu}-\mathrm{U} / \mathrm{kg}$ & 0.102 & 0.087 & $1.16^{\mathrm{bc}}$ & $0.400^{\mathrm{a}}$ & 0.271 & $1.46^{\mathrm{abc}}$ & 3.81 & 0.737 & $1.38^{\mathrm{a}}$ \\
\hline $\mathrm{NC}+600 \beta-\mathrm{Glu}-\mathrm{U} / \mathrm{kg}$ & 0.098 & 0.082 & $1.20^{\mathrm{ab}}$ & $0.386^{\mathrm{ab}}$ & 0.261 & $1.48^{\mathrm{abc}}$ & 3.90 & 0.730 & $1.37^{\mathrm{a}}$ \\
\hline Treatment P-value & 0.228 & 0.2380 & 0.0265 & 0.0180 & 0.1407 & 0.0047 & 0.2671 & 0.2566 & $<0.001$ \\
\hline Treatment SEM & 0.0023 & 0.0023 & 0.0169 & 0.0061 & 0.0045 & 0.0166 & 0.0959 & 0.0098 & 0.0126 \\
\hline Fisher's LSD ${ }^{5}$ & --- & --- & 0.0476 & 0.0173 & --- & 0.0469 & --- & --- & 0.0356 \\
\hline
\end{tabular}

${ }^{1}$ Corn and soybean meal positive control diet.

${ }^{2}$ Corn and soybean meal based positive control with inclusion of $10 \%$ wheat and $10 \%$ DDGS

${ }^{3}$ Similar wheat and DDGS diet as PC_2 but with ME reduced by $125 \mathrm{kcal} / \mathrm{kg}$.

${ }^{4}$ Provided by corn-expressed carbohydrase.

${ }^{5}$ Fisher's least significant difference multiple comparison test (a, b, c).

FI = Feed Intake; LWG = Live weight gain; FCR = Feed conversion ratio calculated using mortality weight; AC1 = Corn-expressed carbohydrase; $\beta$-Glu-U/kg = $\beta$-Glucanase units $/ \mathrm{kg}$ of feed 
Table 6. Pearson correlation coefficients of intestinal viscosity and performance variables ${ }^{1}$

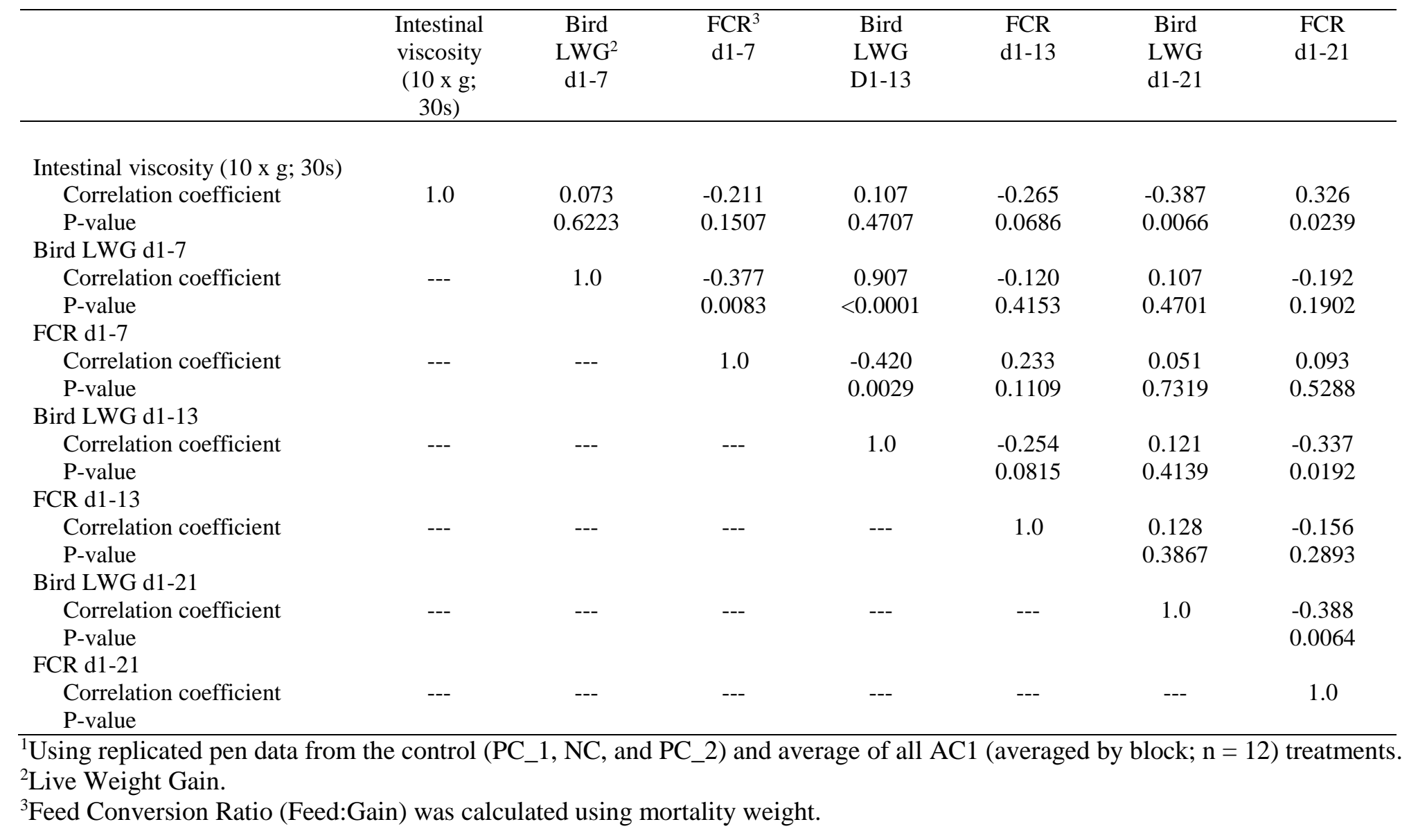


Table 7. Pearson correlation coefficients of intestinal viscosity, dietary viscosity, and performance variables among all treatments analyzed categorically ${ }^{1}$.

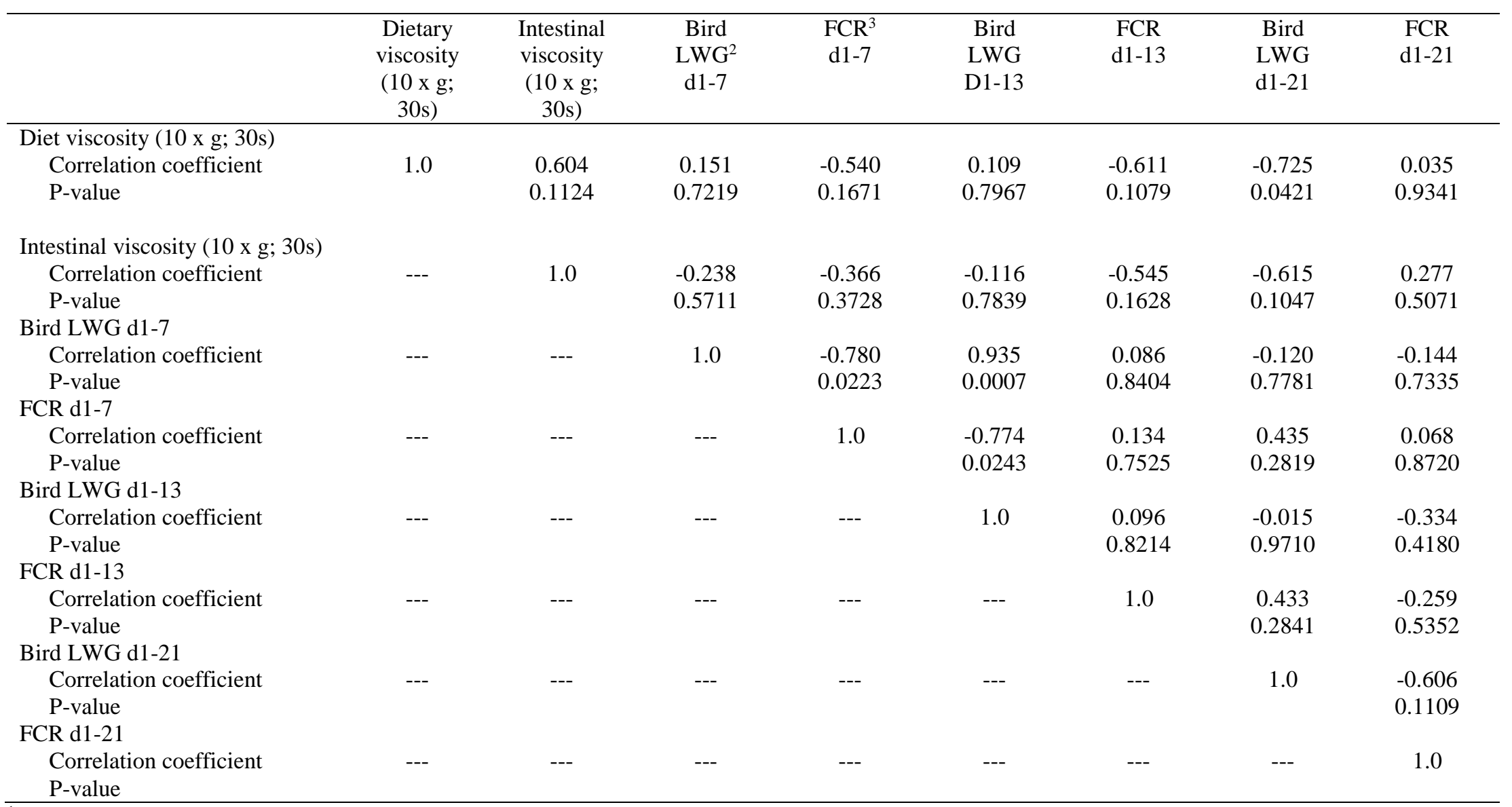

${ }^{1}$ Treatment averages were used for intestinal viscosity and animal performance results.

${ }^{2}$ Live Weight Gain.

${ }^{3}$ Feed Conversion Ratio (Feed:Gain) was calculated using mortality weight. 


\section{CHAPTER THREE}

\section{Exogenous enzyme supplementation can overcome amino acid deficient diets}

$$
\text { V.E. Ayres }{ }^{1} \text {, S.A. Cantley }{ }^{2} \text {, T.P. Boltz }{ }^{1} \text {, A.E. Lamp }{ }^{1} \text { and J.S. Moritz }{ }^{1}
$$

${ }^{1}$ Division of Animal and Nutritional Sciences, West Virginia University, Morgantown, West

Virginia, 26506

Phone: 304-293-1911

Fax: 304-293-2232

${ }^{2}$ Huvepharma, Sofia, Bulgaria

Corresponding Author: Joe.Moritz@mail.wvu.edu

Primary Audience: Feed Manufacturers, Nutritionists, Researchers 
SUMMARY The current study hypothesized that exogenous enzyme supplementation can overcome amino acid deficient corn and soybean based broiler starter diets. The objective of the study was to determine broiler performance of diets that vary in amino acid concentration and enzyme inclusion. Dietary treatments included a positive control (PC) (100\% amino acid recommendations), negative control (NC) (85\% amino acid recommendations), and six additional diets containing commercially available enzyme supplements (Single Dose Phytase, Super Dose Phytase, Single Dose NSPase, Super Dose Phytase + Single Dose NSPase, Protease 1, and Protease 2) added to the NC based on manufacturers' recommendations. Each diet was conditioned at $70^{\circ} \mathrm{C}$ and fed as crumbles to 12 replications of 10 male Hubbard x Ross 708 broiler chicks for $21 \mathrm{~d}$. Treatments were arranged in a randomized complete block design. The $15 \%$ calculated reduction in crude protein and amino acids produced expected 21d broiler live weight gain (LWG) differences between the PC and NC $(P<0.05)$. Dietary treatments including phytase, at either level or when combined with the NSPase, had similar d7, 14, and 21 LWG compared to the PC $(P>0.05)$. These data suggest that with the inclusion of the particular phytase, regardless of dose or when combined with a single dose of NSPase, improved broiler LWG in an amino acid deficient diet to an extent beyond the NSPase alone or either tested protease. 


\section{DESCRIPTION OF THE PROBLEM}

Exogenous enzyme supplementation is a common nutritional practice in the U.S. poultry industry. Previous literature has stated that these enzymes can improve bird performance and aid in least cost diet formulation. Common exogenous enzymes supplemented in diets include phytase, non-starch polysaccharide enzymes (NSPase), and proteases.

Phytases are utilized to decrease negative effects associated with phytate bound Phosphorous (P) [1-3] and may also improve the absorption of protein and amino acids. Yi and co-authors [4] found that the inclusion of a microbial phytase to a corn-soybean meal based diet enhanced growth performance, as well as ileal nitrogen (N) and amino acid (AA) digestibility, and apparent $\mathrm{N}$ and $\mathrm{P}$ retention of turkey poults. The authors hypothesized that phytate has the potential of binding with protein at low and neutral $\mathrm{pH}$ levels, which was suggested by Cosgrove, Anderson, and Thompson [5-7]. In this case, the proteins are positively charged and can form insoluble complexes with the negatively charged phytate $[8,9]$. Ultimately, the binding of proteins to phytate can alter protein structure, thus decreasing solubility, digestibility, and functionality. Therefore, when phytase frees the bound $\mathrm{P}$, it may also free the binding groups of proteins bound to phytate, thereby allowing for better absorption of protein and AA.

The presence of NSPs can lead to increased intestinal viscosity, reduced nutrient digestibility, and increased feed conversion ratio (FCR) [10-13]. To negate the effects associated with NSPs, nutritionists may also include NSPases in the diet. These enzymes have been shown to reduce intestinal viscosity [10] and degrade cell wall polysaccharides [13]. In doing so, endogenous enzymes may have better access to their substrates, ultimately improving diet digestibility. 
Variability of digestible protein and AA may also occur within the same feed ingredient [14-17]. A wide range of endogenous enzymes are produced and released in the broiler gastrointestinal tract and are able to optimize protein utilization [17-19]. However, studies have shown that a portion of the protein in the feed is passing through the gastrointestinal tract is not being utilized by the animal $[16,17]$. Therefore, many nutritionists are choosing to include exogenous protease in poultry diets as well $[17,20]$.

Often times, supplemental enzymes are utilized in combination with one another. Such combinations are referred to as enzyme "cocktails." These enzymes have been shown to act independently of one another and improve broiler performance [21]. For example, Cowieson and Adeola [22] found that a phytase and an enzyme cocktail composed of a xylanase, amylase, and protease can improve nutrient digestibility and broiler performance when supplemented to a diet suboptimal in terms of $\mathrm{Ca}, \mathrm{P}$, and metabolizable energy (ME).

The objectives of this study were to determine digestible amino acid concentrations and performance of broilers fed diets that vary in amino acid concentration and enzyme inclusion.

\section{MATERIALS AND METHODS}

\section{Diet Formulation}

Diets consisted of a positive control (PC), formulated with $100 \%$ of amino acid recommendations by Tillman and Dozier [23] and a negative control (NC), formulated with $85 \%$ of amino acid recommendations and crude protein $(\mathbf{C P})$ relative to the $\mathrm{PC}$. The NC was then supplemented with a Single Dose of Phytase, a Super Dose of Phytase, a Single Dose of NSPase, a Super Dose of Phytase + a Single Dose of NSPase, Protease 1, or Protease 2. Enzyme inclusions followed manufacturer recommendations [24]. All diets were corn-soybean meal based diets, formulated to $3,000 \mathrm{kcal} / \mathrm{kg}$ of ME (Table 1). 
All feed was manufactured at the West Virginia University pilot feed mill. A total of $1,741.15 \mathrm{~kg}$ was made to create a master batch. From this master batch, $226.80 \mathrm{~kg}$ of feed was mixed with a premix specific for the PC diet formulation, containing additional soybean meal, soybean oil, methionine, lysine and threonine. The remaining $1514.35 \mathrm{~kg}$ was mixed with a premix specific for the NC diet formulation, containing additional ground corn and limestone. The NC basal diet was then divided into seven allotments of $226.780 \mathrm{~kg}$ each. One of the seven allotments was kept as the NC diet, and the other six were mixed via top dress with either a Single Dose of Phytase, Super Dose of Phytase, Single Dose of NSPase, Super Dose of Phytase + Single Dose of NSPase, Protease 1, or Protease 2. For each enzyme diet, the enzyme supplements were premixed with a $3 \mathrm{~kg}$ sample of $\mathrm{NC}$ feed in a small Univex paddle mixer [25]. Each batch was then mixed for 10 minutes in a one-ton single screw vertical mixer [26]. Complete feed samples for each treatment were collected post-enzyme addition, randomly throughout the batch, to generate a homogenous sample and sent to a commercial laboratory for proximate analysis [27].

\section{Feed Manufacture}

A $454 \mathrm{~kg}$ corn-soybean meal based diet was used prior to pelleting experimental diets to warm the steel housing of the conditioner and pellet die. All experimental treatments were steam conditioned at $70^{\circ} \mathrm{C}$ for 15 seconds using a California Pellet Mill Conditioner [28] with steam pressure throttled to $276 \mathrm{kpa}$ prior to the Masoneilan Valve and entrance to the conditioner. Treatments were then pelleted at steady state conditions at a constant rate of 1.2 tonne/hr using a 40-horsepower California Pellet Mill [29] with a 4.76 (effective thickness) x 38.1 mm (length) pellet die without relief. Once the target temperature of $70^{\circ} \mathrm{C}$ was obtained, samples of each treatment were taken directly from the pellet die and allowed to cool for approximately 12 minutes [30]. The samples were then sent to a commercial laboratory for enzyme analysis [31]. 
Immediately after pelleting, each treatment was cooled for approximately $1.25 \mathrm{~min}$ on a horizontal cooler belt [32] using forced ambient air. Ambient temperature and humidity can be found in Table 2. After pellets were cooled, they were crumbled through a single pair roller mill [33] to achieve small, uniform crumble size among treatments. All crumbled diets were then stored in an insulated storage room, equipped with a dehumidifier to equilibrate moisture content among the treatments.

Variables measured during feed manufacture included pellet mill motor load [34] and hot pellet temperature (HPT) [35] (Table 2). For each treatment, approximately 100g of hot pellets were collected at the pellet die, as well as approximately $100 \mathrm{~g}$ of cooled pellets from the cooler belt to determine moisture analysis (Table 3) [37].

Pellet quality was assessed one day following feed manufacture, using a New Holmen Portable Pellet Tester [38, 39]. Using a Pfost Tumbler [41], pellet durability index (PDI) and modified pellet durability index (MPDI) also were determined. All PDI and MPDI assays [42] were assessed in duplicate and can be found in Table 2. Particle size of the crumbled feed was also determined, using a Ro-Tap Particle Size Analyzer (Table 2) [43, 44].

\section{Live Bird Performance}

A total of nine-hundred sixty, 1-day-old Hubbard x Ross 708 male chicks were obtained from a commercial hatchery [46]. On d0, the chicks were placed into a group of 10 total chicks, weighed, and the group was then placed in 1 of 96 raised wire cages to create uniform, initial pen weights within block. One of the 8 diets was randomly assigned to each pen within a block. A block consisted of 8 adjacent cages; a total of 12 blocks were utilized. Chicks were housed in raised wire cages in a cross-ventilated, negative-pressure room for $21 \mathrm{~d}$. Two identical rooms were utilized; each containing 48 cages, creating a total of 96 cages. Standard rearing practices were 
applied [47]. The animal performance variables measured included: d0 starting pen weight, d7, 14, and 21 pen weights, feed intake (FI), live weight gain/bird (LWG), mortality corrected FCR and percent mortality. Chicks were not deprived of feed prior to weighing. All animals were reared according to protocols approved by West Virginia University Animal Care and Use Committee.

\section{Statistical Analysis}

All data were analyzed in a randomized complete block design with the raised wire cage location within room determining block. The experimental unit was one pen containing 10 Hubbard x Ross 708 male chicks. The PROC GLM procedure of SAS [SAS 9.4] was used to analyze data by one-way ANOVA. Means were then further separated using Fisher's least significant difference (LSD) post hoc comparison when the ANOVA was significant $(P \leq 0.05)$.

\section{RESULTS AND DISCUSSION}

In the current study, the $15 \%$ reduction in AA recommendations produced expected 7,14 , and 21d broiler LWG differences between the NC and PC dietary treatments $(P<0.05)$. Broiler performance metrics can be observed in Table 4. The addition of phytase to the NC, regardless of dose or combination with the NSPase, was equivalent to the PC for $\mathrm{d} 0-7$, d0-14, and d0-21 LWG $(P>0.05)$. When phytase was included with the NSPase, d0-7 FCR was also similar to the PC $(P$ $>0.05)$. Overall feed intake $(\mathbf{F I})$ for $\mathrm{d} 0-21$ had a similar trend, as all phytase inclusion diets were similar to the PC $(P>0.05)$.

These data are in agreement with $\mathrm{Yi}$ and coauthors [4], as the inclusion of phytase, independent of dose or combination with NSPase, improved growth performance of broilers fed an amino acid deficient diet. Yi and cohorts investigated the effect of a microbial phytase on protein digestibility, AA digestibility, and nitrogen retention of turkey poults fed corn-soybean meal diets. With the addition of $750 \mathrm{U}$ of phytase to corn-soybean meal diets, $\mathrm{N}$ and ileal AA 
digestibility increased, and growth performance was enhanced [4]. The current study also found that with the inclusion of phytase, d0-7, d0-14, and d0-21 LWG was similar to the PC $(P>0.05)$. Overall FI also improved with these inclusions, as treatments including phytase were similar to the PC $(P>0.05)$. Feed conversion ratio was similar between treatments including phytase and the PC as well for d0-21 $(P>0.05)$.

The current study also observed decreased d0-21 LWG and FCR when the NC was supplemented with an NSPase. This is in agreement with Barrios and coauthors [48]. While these authors found that the addition of NSPase can improve growth performance of broilers fed a cornsoybean meal based diet, it was also noted that when dietary treatments were reduced in energy and protein, the NSPase was unable to compensate, and feed efficiency decreased. Similar results were observed in the current study, as the inclusion of NSPase to a diet deficient in amino acid concentration had decreased LWG and increased FCR compared to the PC $(P<0.05)$.

The addition of Protease 1 decreased d21 FCR, similar to that of the PC as well as the NC. This is in agreement with Yan and coauthors [20]. These authors investigated the effects of a protease on growth performance and carcass traits of broilers affected by dietary CP level. These authors found that when birds were fed diets containing low $(18.5 \%)$ or high $(22.5 \%) \mathrm{CP}$, protease significantly decreased FCR on d35 and 42. Similar results were also observed in the current study, as Protease 1 had similar FCR, comparable to the PC $(P>0.05)$.

The addition of Protease 2 to the amino acid deficient diet did not improve FI, LWG, or FCR for any time point during the 21-day study, which is in agreement with Lahaye and coauthors [49]. These authors evaluated the effect of supplementation of 2 single protease enzymes (PoultryGrow 250 and a protease from Bacillus origin) on top of commercial pelleted cornsoybean meal based diets with reduced CP, AA, and energy levels for 35 days. These authors 
found that the inclusion of PoultryGrow 250 to the CP, AA, and energy deficient diet significantly improved d28 and d35 body weight. However, there were no differences in FCR. These authors concluded that the use of the same protease used in the current study on top of a commercial pelleted diet, deficient in $\mathrm{CP}$, AA, and energy has the potential to improve body weight and maintain FCR of birds. In the current study, however, the authors found no improvement in LWG or FCR. However, the current study was a 21-day study while Lahaye and coauthors evaluated various proteases for 35 days [49]. The authors hypothesize that both proteases utilized may have a greater effect on growth performance later in life.

In conclusion, the $15 \%$ reduction in $\mathrm{CP}$ and $\mathrm{AA}$ produced expected 7,14 , and $21 \mathrm{~d}$ broiler LWG differences between the PC and NC dietary treatments. Phytase, independent of dose or combination with the NSPase, and Protease 1 produced 21d FCR similar to the PC. Finally, feeding NC with the NSPase or Protease 2 did not restore 21d LWG comparable to the PC.

\section{CONCLUSIONS AND APPLICATIONS}

1. The $15 \%$ reduction in $\mathrm{CP}$ and $\mathrm{AA}$ produced expected 7,14 and $21 \mathrm{~d}$ broiler LWG differences between the PC and NC.

2. Dietary treatments including phytase, at either level or when combined with the NSPase, had similar d7, 14 and 21 LWG compared to the PC, while feeding NC with the NSPase or either protease did not. 


\section{REFERENCES AND NOTES}

1. Shirley, R.B. and H.M. Edwards, Jr. 2003. Graded Levels of Phytase Past Industry Standards Improves Broiler Performance. Poult. Sci. 82:671-680.

2. Walk, C.L., M.R. Bedford, T.S. Santos, D. Paiva, J.R. Bradley, H. Wladecki, C. Honaker, and A.P. McElroy. 2013. Extra-phosphoric effects of superdoses of a novel microbial phytase. Poult. Sci. 92:719-725.

3. Walk, C.L., T.T. Santos, and M.R. Bedford. 2014. Influencce of superdoses of a novel microbial phytase on growth performance, tibia ash, and gizzard phytate and inositol in young broilers. Poult. Sci. 93:1172-1177.

4. Yi, Z., E.T. Kornegay, and D.M. Denbow. 1996. Effect of Microbial Phytase on Nitrogen and Amino Acid Digestibility and Nitrogen Retention of Turkey Poults Fed Corn-Soybean Meal Diets. Poult. Sci. 75:979-990.

5. Cosgrove, D.J. 1980. Inositol phosphates: their chemistry, biochemistry, and physiology. Elsevier Science Publishing Co., New York, NY.

6. Anderson, P.A. 1985. Interactions between proteins and constituents that affect protein quality. Pages 31-46 in Digestibility and Amino Acid Availability in Cereals and Oilseeds. G.W. Finley and D.T. Hopkins, ed. American Association of Cereal Chemists. St. Paul, MN.

7. Thompson, L.U. 1986. Phytic acid: A factor infulencind starch digestibility and blood glucose response. Pages 173-194 in Phytic Acid: Chemistry and Applications. .E. Graf, ed. Pilatus Press, Minneapolis, MN.

8. Cheryan, M. 1980. Phytic acid interactions in food systems. CRC Crit. Rev. Food Sci. Nutr. 13:297-335.

9. Reddy, N.R., C.V. Balakrishnan, and D.K. Salunkhe. 1982. Phytates in legumes. Adv. Food Res. 28:1-92.

10. Bedford, M. R., and H. L. Classen. 1992. Reduction of intestinal viscosity through manipulation of dietary rye and pentosanase concentation is effected through changes in the carbohydrate composition of the intestinal aqueous phase and results in improved growth rate and food conversion efficiency of broiler chicks. J. Nutr. 122:560-569.

11. Bedford, M. R., and A. J. Morgan. 1996. The use of enzymes in poultry diets. World's Poult. Sci. J. 52:61-68.

12. Lázaro, R., M. Gracia, M. J. Aranibar, and G. G. Mateos. 2003. Effect of enzyme addition to wheat-, barley- and rye-based diets on nutrient digestibility and performance of laying hens. Br. Poult. Sci. 84:37-47.

13. Meng, X., and B. A. Slominski. 2005. Nutritive values of corn, soybean meal, canola meal, and peas for broiler chickens as affected by a multicarbohydrase preparation of cell wall degrading enzymes. Poult. Sci. 84:1242-1251.

14. Parsons, C. M., F. Castanon, and Y. Han. 1997. Protein and amino acid quality of meat and bone meal. Poult. Sci. 76:361-368.

15. Parsons, C. M., K. Hashimoto, K. J. Wedeking, Y. Han, and D. H. Baker. 1992. Effect of overprocessing on availability of amino acids and energy in soybean meal. Poult. Sci. 71:133-140.

16. Lemme, A., V. Ravindran, and W. L. Bryden. 2004. Ileal digestibility of amino acids in feed ingredients for broilers. World's Poult. Sci. 60:423-437. 
17. Freitas, D.M., S.L. Vieira, C.R. Angel, A. Favero, and A. Maiorka. 2011. Performance and nutrient utilization of broilers fed diets supplemented with a novel mono-component protease. J. Appl. Poult. Res. 20:322-334.

18. Nir, I., Z. Nitsan, and M. Mahagna. 1993. Comparative growth and development of the digestive organs and of some enzymes in broiler and egg type chicks after hatching. $\mathrm{Br}$. Poult. Sci. 34:523-532.

19. Le Huerou-Luron, I., E. Lhoste, C. Wicker-Planquart, N. Dakka, R. Toullec, T. Corring, P. Guilloteau, and A. Puigserver. 1993. Molecular aspects of enzyme synthesis in the exocrine pancreas with emphasis on development and nutritional regulation. Proc. Nutr. Soc. 52:301-313.

20. Yan, F., M. Vazquez-Anon, and N. Odetallah. 2014. Effect of protease on growth performance and carcass traits of broilers fed diets with different crude protein levels. Poult. Sci. 93(E-Suppl. 1):65. (Abstr.).

21. Juanpere, J., A.M. Pérez-Vendrell, E. Angulo, and J. Brufau. 2005. Assessment of potential interactions between phytase and glycosidase enzyme supplementation on nutrient digestibility in broilers. Poult. Sci. 84: 571-580.

22. Cowieson, A.J. and O. Adeola. 2005. Carbohydrases, Protease, and Phytase Have an Additive Beneficial Effect in Nutritionally Marginal Diets for Broiler Chicks. Poult. Sci. 84:1860-1867.

23. Tillman, P. B. and W.A. Dozier. 2013. Current Amino Acid Considerations for Broilers: Requirements, Ratios, Economics.

24. Cibenza DP 100; Hostazym X (1,500 EPU/kg); OptiPhos 2000 PF (single dose:250 FTU/kg; super dose: 1,500 FTU/kg); and PoultryGrow 250.

25. Univex Corp., Salem, NH.

26. Vertical mixer, Avery Weigh-Tronix, Fairmont, MN.

27. NP Analytical Laboratories, St. Louis, MO.

28. California Pellet Mill Company, Crawfordsville, IN.

29. Master Model Pellet Mill, California Pellet Mill Company, Crawfodsville, IN.

30. Reese, D.A., K.L. Foltz, and J.S. Moritz. 2017. Effect of mixing and sampling method on pelleted feed nutrient analysis and diet formulation validation. J. Appl. Poult. Res. 26:219225.

31. Huvepharma, Sofia, Bulgaria.

32. Vertical cooler, Pyramid Processing Equipment LLC, Stilwell, KS.

33. Badger Roller Mill, Model: BN136.

34. A 100\% motor load was based on FLA (full load amps) that was 47 amps based on the pellet mill motor name plate.

35. Hot pellet temperature was measured by placing an insulated container under the pellet mill to catch hot pellets directly from the pellet die and immediately closing the lid. A thermocouple thermometer [36] with an $80 \mathrm{PK}-24$ temperature probe was then placed into the container and the highest temperature was recorded as HPT for each treatment.

36. Fluke 51 II, Everette, WA.

37. AOAC. 2006. Moisture in Animal Feed. Official Method 934.01, Gaithersburg, MD.

38. New Holmen NHP portable pellet durability tester, Lignotech, USA, Inc., Rothschild, WI.

39. One hundred grams of pellets were sifted through a No. 6 American Society for Testing and Materials (ASTM) screen [40], placed in a holding chamber, blown by a jet of air for 
30s, and weighed, yielding a direct read of pellet durability, as fines are removed during the blowing process.

40. American Society for Testing and Materials. West Conshohoken, PA.

41. American Society of Agricultural Engineers. 1997. ASAE S269.4. Cubes, pellets, and crumbles-Definitions and methods for determining density, durability, and moisture. Am. Soc. Agric. Eng., St. Joseph, MI.

42. Pellets were first sifted in a No. 6 ASTM screen [40]. Five hundred grams of sifted pellets were then placed in a dust-tight enclosure and tumbled for $10 \mathrm{~min}$ at $50 \mathrm{rpm}$. The enclosure dimensions were $12 \times 12$ in., with a $2 \times 9$ in. plate fixed along one of the $12 \times 12$ in. sides. After tumbling, the samples were then sifted again using a No. 6 ASTM screen and weighed. Pellet durability index was then calculated by dividing the weight of the pellets after tumbling by the weight of the pellets prior to tumbling, and multiplied by 100 . Modified pellet durability index (MPDI) was determined in a similar fashion, with the exception of the addition of five $13 \mathrm{~mm}$ hex nuts to the pre-tumbled sample to obtain added pellet agitation.

43. Ro-Tap Particle Size Analyzer, W.S. Tyler, Mentor, OH.

44. One hundred grams of each crumbled diet was placed in a dust-tight enclosed series of stacked ASTM screens affixed to the Ro-Tap Particle Size Analyzer and shaken for 10 minutes. The screens were then separated and weighed. Particle size was then determined by subtracting the weight of the screen from the final weight of the screen and sample after shaking. The mean geometric particle size and log normal geometric standard deviation were calculated as described by McEllhiney [45].

45. McEllhiney, R.R. 1994. Feed Manufacturing Industry.

46. Longenecker's Hatchery, Elizabethtown, PA.

47. Room temperature for the 1-day-old chicks was set at $32^{\circ} \mathrm{C}$, and gradually decreased to $29^{\circ} \mathrm{C}$ for the second week and $26^{\circ} \mathrm{C}$ for the third week of the study, to create optimal rearing conditions. Feed was placed in external feed troughs and water was supplied through a nipple drinker system; both feed and water were provided for ad libitum consumption. Lighting was manipulated through grow-out to ensure that birds had a full gastrointestinal tract when sampled on d21. From d1 to 6, birds were exposed to $24 \mathrm{~h}$ light, and after d6, the hours of light were decreased gradually until $6 \mathrm{~h}$ dark was reach on d20 and 21.

48. Barrios, M.A., J. Payne, D. Morris, A. Kenyon, L. Fuller, A. Batal, and R. Beckstead. 2014. Efficacy of a xylanase (Hostazym X) on broiler performance from 1 to 18 days of age over the course of three broiler trials. Poult. Sci. 93(E-Suppl. 1):368. (Abstr.).

49. Lahaye, L., D. Detzler, J.C. Bodin, and R. Bilodeau. 2014. Comparison of proteases added on top of commercial pelleted diets reduced in CP, AA, and energy. Poult. Sci. 93(E-Suppl. 1):65. (Abstr.). 
Table 1. Diet formulation fed for 21d trial.

\begin{tabular}{|c|c|c|}
\hline & \multicolumn{2}{|c|}{ Inclusion $(\%)$} \\
\hline Ingredients & Positive Control & Negative Control \\
\hline Corn & 53.77 & 62.31 \\
\hline Soybean Meal & 37.61 & 30.14 \\
\hline Soybean Oil & 3.7 & 2.72 \\
\hline Dicalcium Phosphate & 1.79 & 1.84 \\
\hline Limestone & 1.33 & 1.35 \\
\hline DL- Methionine & 0.49 & 0.39 \\
\hline Salt & 0.33 & 0.33 \\
\hline Threonine & 0.30 & 0.25 \\
\hline Poultry Vitamin/Mineral Premix & 0.25 & 0.25 \\
\hline Titanium dioxide & 0.20 & 0.20 \\
\hline L- Lysine $\mathrm{HCl}$ & 0.14 & 0.13 \\
\hline Sodium Bicarbonate & 0.10 & 0.10 \\
\hline \multicolumn{3}{|c|}{ Calculated Nutrients } \\
\hline Metabolizable Energy (Kcal/kg) & 3,000 & 3,000 \\
\hline Crude Protein (\%) & 22.20 & 19.00 \\
\hline Calcium (\%) & 1.01 & 1.01 \\
\hline Phosphorous (\%) & 0.46 & 0.46 \\
\hline Sodium $(\%)$ & 0.17 & 0.17 \\
\hline Dig. Lysine (\%) & 1.20 & 1.02 \\
\hline Dig. Methionine (\%) & 0.79 & 0.66 \\
\hline Dig. Methionine + Cystine $(\%)$ & 1.08 & 0.92 \\
\hline Dig. Threonine $(\%)$ & 1.01 & 0.86 \\
\hline Dig. Tryptophan (\%) & 0.24 & 0.20 \\
\hline \multicolumn{3}{|c|}{ Analyzed Nutrients } \\
\hline Crude Fat $(\%)$ & 5.27 & 4.82 \\
\hline Crude Protein $(\%)$ & 20.60 & 18.97 \\
\hline Methionine (\%) & 0.78 & 0.68 \\
\hline Lysine $(\%)$ & 1.25 & 1.17 \\
\hline Threonine $(\%)$ & 0.95 & 0.90 \\
\hline
\end{tabular}

${ }^{1}$ Metabolizable Energy and Available Phosphorus were based on Agristat values as suggested by M. Donohue. 2013. The Challenges in Feeding Broilers in Times of High and Volatile Feed Ingredient Costs: How to Cover the Costs? 2013 Mid-Atlantic Nutrition Conference proceedings. Digestible amino acids were based on the digestible lysine value (1.2\%) suggested by P. B. Tillman and W.A. Dozier. 2013. Current Amino Acid Considerations for Broilers: Requirements, Ratios, Economics. www.thepoultryfederation.com for $8-14$ day broilers. Digestible amino acid to digestible lysine ratios followed further recommendations of this communication (minimum of 0.54 methionine, 1.02 TSAA, 0.90 threonine, 0.21 tryptophan.

${ }^{2}$ Supplied per kg of diet: manganese, $0.02 \%$; zinc $0.02 \%$; iron, $0.01 \%$; copper, $0.0025 \%$; iodine, $0.0003 \%$; selenium, $0.00003 \%$; folic acid, $0.69 \mathrm{mg}$; choline, 386mg' riboflavin, $6.61 \mathrm{mg}$; biotin, $0.03 \mathrm{mg}$; vitamin B6, $1.38 \mathrm{mg}$; niacin, $27.56 \mathrm{mg}$; pantothenic acid, $6.61 \mathrm{mg}$; thiamine, $2.20 \mathrm{mg}$; manadione, $0.83 \mathrm{mg}$; vitamin B12, $0.01 \mathrm{mg}$; vitamin E, 16.53 IU; vitamin D3, 2133 ICU; vitamin A, 7716 IU. 
Table 2. Descriptive feed manufacture data from WVU Feed Mill on January 16, 2019. Pellets were manufactured using a 40 Horsepower California Pellet Mill and were extruded through a 4.8 x $38 \mathrm{~mm}$ pellet die.

\begin{tabular}{|c|c|c|c|c|c|c|c|}
\hline Treatment & $\begin{array}{c}\text { Hygienizer } \\
\text { Temperature }{ }^{4}\left({ }^{\circ} \mathrm{C}\right)\end{array}$ & $\begin{array}{c}\text { Motor } \\
\operatorname{Load}^{5}(\%)\end{array}$ & $\begin{array}{c}\text { Hot Pellet } \\
\text { Temperature }^{6}\left({ }^{\circ} \mathrm{C}\right)\end{array}$ & PDI & MPDI & NHPT $^{7}$ & $\begin{array}{c}\text { Particle Size }^{8} \\
\text { (microns) }\end{array}$ \\
\hline Positive Control (PC) & 56 & 49 & 72.5 & 78 & 71 & 65 & 1,473 \\
\hline Negative Control (NC) & 60 & 48 & 72.2 & 78 & 71 & 64 & 1,503 \\
\hline $\mathrm{NC}+$ Single dose Phytase & 58 & 49 & 72.1 & 79 & 74 & 71 & 1,495 \\
\hline $\mathrm{NC}+$ Single dose NSPase & 56 & 50 & 72.6 & 81 & 76 & 72 & 1,337 \\
\hline $\begin{array}{l}\mathrm{NC}+\text { Super dose Phytase } \\
+ \text { Single dose NSPase }\end{array}$ & 57 & 50 & 72.9 & 80 & 74 & 69 & 1,459 \\
\hline $\mathrm{NC}+$ Protease 2 & 56 & 49 & 73.7 & 78 & 73 & 66 & 1,321 \\
\hline
\end{tabular}

${ }^{1}$ The following metrics were recorded on day of feed manufacture: Ambient Temperature $\left(0.56{ }^{\circ} \mathrm{C}\right)$; Ambient Humidity (85\%); Conditioner Retention Time (15 s); Conditioning Temperature ${ }^{3}\left(70^{\circ} \mathrm{C}\right)$.

${ }^{2}$ Production rate was maintained at 1.2 tonne/hr for all treatments.

${ }^{3}$ Conditioning temperature was measured as the reading from the conditioner temperature probe at the time of sample collection.

${ }^{4}$ The hygienizer was not turned on during this experiment; however, feed must run through the hygienzer for 45 seconds post conditioning and prior to pellet die extrusion based on the WVU feed manufacture system.

${ }^{5} \mathrm{~A} 100 \%$ motor load was based on FLA (full load amps) that was 47 amps based on the pellet mill motor name plate.

${ }^{6}$ Hot pellet temperature was determined on pellets directly following extrusion from the die. Pellets were collected into an insulated container and temperature was measured using a thermocouple thermometer and an 80PK-24 temperature probe.

${ }^{7}$ Measurements New Holmen Pellet Tester are where $100 \mathrm{~g}$ pelleted samples are subjected to air flow within a perforated chamber for $30 \mathrm{~s}$.

${ }^{8}$ Particle size determined with a Ro-Tap particle size analyzer model RX-29 Type 110V 60H2. 
Table 3. Mash and Pellet Moisture

\begin{tabular}{cccc}
\hline Treatment & Mash \% Moisture & Cool Pellet \% Moisture & Hot Pellet \% Moisture \\
\hline Positive Control (PC) & 12 & 14 & 14 \\
Negative Control (NC) & 12 & 14 & 14 \\
NC + Single dose Phytase & 12 & 14 & 16 \\
NC + Super dose Phytase & 13 & 14 & 16 \\
NC + Single dose NSPase & 12 & 14 & 16 \\
NC + Super dose Phytase + Single & 12 & 14 & 16 \\
dose NSPase & 12 & 14 & 16 \\
NC + Protease 1 & 13 & 16 \\
NC + Protease 2 & 12 & \\
\hline
\end{tabular}


Table 4. Growth performance of broilers fed diets varying in enzyme supplementation.

\begin{tabular}{|c|c|c|c|c|c|c|c|c|c|}
\hline \multirow[b]{2}{*}{ Diet Formulation } & \multicolumn{3}{|c|}{ Days 0-7 } & \multicolumn{3}{|c|}{ Days 0-14 } & \multicolumn{3}{|c|}{ Days $0-21$} \\
\hline & $\begin{array}{c}\text { Bird FI } \\
(\mathrm{kg})\end{array}$ & $\begin{array}{c}\text { Bird } \\
\mathrm{LWG}^{3} \\
(\mathrm{~kg})\end{array}$ & $\begin{array}{c}\mathrm{FCR}^{4} \\
(\mathrm{~kg} / \mathrm{kg})\end{array}$ & $\begin{array}{c}\text { Bird FI } \\
(\mathrm{kg})\end{array}$ & $\begin{array}{l}\text { Bird } \\
\text { LWG } \\
(\mathrm{kg})\end{array}$ & $\begin{array}{c}\text { FCR } \\
(\mathrm{kg} / \mathrm{kg})\end{array}$ & $\begin{array}{c}\text { Bird FI } \\
(\mathrm{kg})\end{array}$ & $\begin{array}{c}\text { Bird } \\
\text { LWG } \\
(\mathrm{kg})\end{array}$ & $\begin{array}{c}\text { FCR } \\
(\mathrm{kg} / \mathrm{kg})\end{array}$ \\
\hline Positive Control (PC) & 0.168 & $0.159^{\mathrm{a}}$ & $1.05^{\mathrm{e}}$ & 0.668 & $0.483^{\mathrm{a}}$ & $1.24^{\mathrm{e}}$ & $1.44^{\mathrm{a}}$ & $0.946^{\mathrm{a}}$ & $1.49^{\mathrm{bc}}$ \\
\hline Negative Control (NC) & 0.156 & $0.140^{c}$ & $1.12^{\mathrm{c}}$ & 0.641 & $0.423^{\mathrm{b}}$ & $1.31^{\mathrm{bcd}}$ & $1.38^{\mathrm{bcd}}$ & $0.895^{\mathrm{b}}$ & $1.48^{\mathrm{c}}$ \\
\hline $\mathrm{NC}+$ Single dose Phytase & 0.173 & $0.155^{\mathrm{a}}$ & $1.11^{\mathrm{c}}$ & 0.666 & $0.460^{\mathrm{a}}$ & $1.30^{\mathrm{bcd}}$ & $1.43^{\mathrm{ab}}$ & $0.950^{\mathrm{a}}$ & $1.46^{\mathrm{c}}$ \\
\hline $\mathrm{NC}+$ Super dose Phytase & 0.169 & $0.155^{\mathrm{a}}$ & $1.08^{\mathrm{d}}$ & 0.671 & $0.468^{\mathrm{a}}$ & $1.29^{\mathrm{cd}}$ & $1.42^{\mathrm{ab}}$ & $0.953^{\mathrm{a}}$ & $1.46^{\mathrm{c}}$ \\
\hline $\mathrm{NC}+$ Single dose NSPase & 0.159 & $0.141^{\mathrm{c}}$ & $1.12^{\mathrm{bc}}$ & 0.636 & $0.424^{\mathrm{b}}$ & $1.33^{\mathrm{ab}}$ & $1.37^{\mathrm{cd}}$ & $0.588^{b c}$ & $1.56^{\mathrm{ab}}$ \\
\hline $\begin{array}{c}\mathrm{NC}+\text { Super dose Phytase }+ \\
\text { Single dose NSPase }\end{array}$ & 0.162 & $0.152^{\mathrm{ab}}$ & $1.07^{\mathrm{de}}$ & 0664 & $0.463^{\mathrm{a}}$ & $1.28^{\mathrm{d}}$ & $1.42^{\mathrm{abc}}$ & $0.946^{\mathrm{a}}$ & $1.47^{\mathrm{c}}$ \\
\hline $\mathrm{NC}+$ Protease 1 & 0.162 & $0.142^{\mathrm{bc}}$ & $1.15^{\mathrm{a}}$ & 0.634 & $0.429^{\mathrm{b}}$ & $1.33^{\mathrm{bc}}$ & $1.359^{\mathrm{cd}}$ & $0.875^{\mathrm{bc}}$ & $1.52^{\mathrm{abc}}$ \\
\hline $\mathrm{NC}+$ Protease 2 & 0.163 & $0.141^{b c}$ & $1.14^{\mathrm{ab}}$ & 0.648 & $0.422^{\mathrm{b}}$ & $1.36^{\mathrm{a}}$ & $1.357^{\mathrm{d}}$ & $0.846^{\mathrm{c}}$ & $1.58^{\mathrm{a}}$ \\
\hline Treatment P-value & 0.1833 & 0.0010 & $<0.0001$ & 0.1208 & $<0.0001$ & $<0.0001$ & 0.0147 & $<0.0001$ & 0.0035 \\
\hline Treatment SEM & 0.0045 & 0.0040 & 0.0065 & 0.0115 & 0.0084 & 0.0119 & 0.0204 & 0.0164 & 0.0254 \\
\hline Fisher's LSD ${ }^{1}$ & --- & 0.0113 & 0.0183 & --- & 0.0237 & 0.0336 & 0.0575 & 0.0463 & 0.0714 \\
\hline
\end{tabular}

${ }^{1}$ Fisher's least significant difference multiple comparison test $(a, b, c)$.

${ }^{2}$ Feed intake.

${ }^{3}$ Live weight gain.

${ }^{4}$ Feed conversion ratio.

${ }^{\mathrm{a}-\mathrm{c}}$ Means with superscripts without a common letter differ significantly $(\mathrm{P}<0.05)$. 


\section{CHAPTER FOUR}

The effect of corn-expressed carbohydrase on performance and digesta viscosity of broilers fed a high non-starch polysaccharide diet

Ayres, V. ${ }^{1}$, H. L. Baldwin ${ }^{1}$, X. Li ${ }^{2}$, H. Xu' ${ }^{2}$, R. M. Raab ${ }^{2}$, J. W. Boney ${ }^{1}$, J. N. Broomhead ${ }^{2}$ J. S. Moritz ${ }^{1, ¥}$

${ }^{1}$ Division of Animal and Nutritional Sciences, West Virginia University, Morgantown, West Virginia, 26506

Phone: 304-293-1911

Fax: 304-293-2232

${ }^{2}$ Agrivida Inc., Woburn, MA 
SUMMARY Study objectives were to determine the effects of a corn-expressed recombinant carbohydrase (AC1) on broiler performance and digesta viscosity in high NSP diets through $21 \mathrm{~d}$ of age. One day-old Hubbard x Cobb 500 chicks were assigned to six dietary treatments. Each treatment consisted of 12 replicate pens of 10 birds. The positive control diet (PC) was a corn and soybean meal formulation. The negative control diet (NC) included $10 \%$ wheat and $10 \%$ corn distiller's dried grains with solubles (DDGS). The NC contained $100 \mathrm{kcal} / \mathrm{kg}$ less ME than the PC. Increasing inclusions of AC1 were applied to the NC to contain 50, 100, 200, and $400 \mathrm{U} \beta$ Glucanase ( $\boldsymbol{\beta}$-Glu-U) per kg of feed. Preliminary experiments demonstrated AC1 homogeneity and stability post pelleting. Live weight gain (LWG) was the highest for PC fed birds from 1 to $14 \mathrm{~d}$; however, birds fed NC with $400 \beta$-Glu-U/kg had similar LWG as PC $(P>0.05)$. Day 1 to 21 FCR was lowest for PC fed birds; however, birds fed NC with $400 \beta$-Glu-U/kg had similar FCR as PC $(P>0.05)$. Birds fed NC had lower LWG and higher viscosity than birds fed PC on d $14(P$ $<0.05)$, but not on d $21(P>0.05)$. Birds fed NC with 200 or $400 \beta$-Glu-U/kg had similar $14 \mathrm{~d}$ digesta viscosity as birds fed PC $(P>0.05)$. These data indicate that NSP ingredients may have a greater impact on digesta viscosity early in broiler growth and that AC1 at 200 and $400 \beta$-Glu$\mathrm{U} / \mathrm{kg}$ produced similar results to PC.

Key words: $\beta$-glucanase, non-starch polysaccharides, performance, viscosity, wheat 


\section{DESCRIPTION OF PROBLEM}

Least-cost diet formulation and geographical location may create an economic incentive to partially replace corn and soybean meal with alternative ingredients in broiler diets. However, alternative ingredients often increase the level of anti-nutritional factors (ANF) within the diet. Corn derived distillers dried grains with solubles (DDGS) contain lower amounts of starch and increased levels of non-starch polysaccharides (NSP) relative to corn [1]. In addition, alternative cereal grains such as wheat contain NSPs at concentrations that may be detrimental to broiler performance [2]. The NSPs are not only indigestible, but can increase digesta viscosity and therefore decrease overall digestibility of all nutrients within the diet. The specific NSP, $\beta$-glucan, found at high levels in wheat and DDGS, is partially water soluble which leads to the formation of a gel-like viscosity within the gastrointestinal tract of the broiler [3]. Viscous digesta reduces the rate of diffusion of feed substrates, digestive enzymes and their products; thereby, reducing absorption of nutrients within the diet. In addition, $\beta$-glucans can increase microflora growth as well as wet, sticky excreta $[3,4,5]$.

Broilers do not produce adequate amounts of endogenous enzymes to digest NSPs. Therefore, exogenous enzymes can be added to diets for compensation $[6,7,8,9]$. Since the early 1960's, research has been conducted on enzyme additions to poultry diets, e.g. NSP-degrading enzyme or carbohydrase, to increase nutrient digestibility and subsequent broiler performance [10, $11,12,13]$. Among the supplemented enzymes, $\beta$-glucanase, a hydrolytic enzyme targeting betaglycosidic bonds in barley, oat or wheat-based diets, has been shown to improve feed conversion efficiency, lower intestinal viscosity, and increase feed intake $[14,15,16,17,18,19]$.

Exogenous enzyme applications have historically been microbial expressed products that are presented in either a granulated, coated, or liquid form. An alternative to these traditional, 
more established animal nutrition enzyme products, are recombinant enzymes produced in transgenic grain $[20,21,22,23,24,25]$. A recombinant carbohydrase, with endo- $\beta-1,4$-glucanase activity, was expressed in corn grain (AC1, Agrivida) using methods described previously [26]. The enzyme in AC1 is a variant of the Thermotoga maritima Cel5A endoglucanase, engineered to improve its thermal stability. AC1 has multiple activities such as endo-cellulase, cellobiohydrolase (exo-cellulase), $\beta$-xylosidase, and $\beta$-1,3-glucanase, but its primary activity is endo-1,4- $\beta$-glucanase. The AC1 gene encodes a $38 \mathrm{kDa}$ protein and is stable at and over $80^{\circ} \mathrm{C}$, the growth temperature of T. maritima.

The current study investigated the effects of feeding AC1 on performance and digesta viscosity of young broilers consuming a corn/soy diet with $10 \%$ wheat and 10\% DDGS.

\section{MATERIALS AND METHODS}

\section{Preliminary Experiments}

Protein Extraction for AC1 Enzyme Activity Assay. Twenty grams of ground AC1 was mixed with $100 \mathrm{~mL}$ of protein extraction buffer (100mM sodium phosphate, $0.01 \%$ Tween $20, \mathrm{pH}$ 6.5) which was pre-warmed at $60^{\circ} \mathrm{C}$. The sample and buffer mixture was placed in a temperaturecontrol shaker [27] to shake at $250 \mathrm{rpm}, 60^{\circ} \mathrm{C}$ for one hour. After one hour of protein extraction, $1 \mathrm{~mL}$ of the mixture was centrifuged at $16,300 \mathrm{x} \mathrm{g}$ for 10 minutes in a bench top centrifuge [28]. The resulting supernatant was saved and used to measure the AC1 enzyme activity in the samples.

AC1 Enzyme Activity Assay. $\beta$-Glucanase activity was measured using a colorimetric assay that relies on hydrolysis of a labeled, commercial substrate, azurine-cross linked barley $\beta$ glucan from Megazyme [29, 30]. Hydrolysis of this substrate by AC1 produces water-soluble dyed 
fragments, and the rate of release of these dyed fragments can be related directly to enzyme activity by measuring the absorbance at $590 \mathrm{~nm}$ (A590).

Fifty microliters of diluted protein extract from $\mathrm{AC} 1$, or $100 \mu \mathrm{L}$ of protein extract from feed, was mixed with one tablet substrate in $450 \mu \mathrm{L}$ (product assay) or $400 \mu \mathrm{L}$ of protein extraction buffer (feed assay) in a 2 mL 96-well block [31]. A blank (500 $\mu$ L extraction buffer without protein extracts) was also included in the block. After a short vortex of the block at a low speed, the block was incubated at $80^{\circ} \mathrm{C}$ water bath for one hour. Enzyme reactions were stopped by adding $1 \mathrm{~mL}$ of $2 \%$ Tris base solution to each reaction. After centrifugation of the block at $3000 \times \mathrm{g}$ for 10 minutes, $100 \mu \mathrm{L}$ of the supernatant was removed to a new flat-bottom microplate [32] to record absorbance at $590 \mathrm{~nm}$.

AC1 $\beta$-glucanase activity was calculated by subtracting the average value of the blank samples from the A590 value of each experimental sample reaction to calculate a background corrected A590 measurement. The corrected A590 measurement of each sample was divided by the sample dry weight to calculate a grain-based specific activity (A590/g of flour or A590/kg of feed). Based on previous experiments, the colorimetric activity data can be converted to the $\beta$ glucanase activity units by multiplying by 0.009 to be presented as unit/g (U/g) flour or unit/kg $(\mathrm{U} / \mathrm{kg})$ feed. The $\beta$-glucanase activity unit is defined as $1 \mu \mathrm{mol}$ of glucose reducing equivalents released from a substrate per minute by enzyme hydrolysis under an optimal assay condition.

Homogeneity of AC1 in Feed. Ground AC1 corn grain was mixed into a standard cornsoybean meal broiler diet. A $1,225 \mathrm{~kg}$ batch of feed was mixed in a vertical mixer with $4.232 \mathrm{~kg}$ of $\mathrm{AC} 1$ product that had an activity of $145 \mathrm{unit} / \mathrm{g}$ to make a diet with a target dose of $500 \mathrm{unit} / \mathrm{kg}$ diet. Ten $0.5 \mathrm{~kg}$ samples were collected randomly from the mixed feed and the $\beta$-glucanase activity was measured as described above. 
Pelleting Stability of AC1 . To demonstrate AC1 stability in pelleted feed, $4.232 \mathrm{~kg}$ of ground $\mathrm{AC} 1$ corn meal was mixed into a $1,225 \mathrm{~kg}$ batch of feed to prepare diets with $\mathrm{AC} 1$ at a target dose of 500 unit $/ \mathrm{kg}$. This batch of feed was pelleted using a conditioning temperature of either 80,85 , or $90^{\circ} \mathrm{C}$ for 10 seconds and extruded through a 4 x $38 \mathrm{~mm}$ pellet die at approximately 0.91 metric ton/hr using a 40-horsepower California Pellet Mill. The steam used in the mill had an incoming pressure of $262 \mathrm{kPa}$. Pellets were cooled using a horizontal belt cooler and ambient air. Pellet conveyance post extrusion and cooling was accomplished with a series of flat bottom drag-chain conveyers and a bucket elevator. Ten $0.5 \mathrm{~kg}$ samples of the mash feed prior to pelleting and three $0.5 \mathrm{~kg}$ samples of post-pelleting feeds from each temperature treatment were collected for $\beta$-Glucanase activity analysis. The $\beta$-Glucanase activities after pelleting at the different temperatures were presented as a percentage of the original activity in the respective mash diets.

\section{Broiler Experiment}

Diet Formulations. Diets varied in ingredients, calculated ME and $\mathrm{AC} 1$ inclusion. The positive control diet (PC) was corn and soybean meal based (Table 1) and contained 3,000 kcal/kg of calculated ME. The negative control diet (NC) was formulated to be $100 \mathrm{kcal} / \mathrm{kg}$ calculated ME less than the PC and contained a 10\% inclusion of both wheat and DDGS. Four additions of AC1, containing 50, 100, 200, and $400 \mathrm{U} \beta$-Glucanase ( $\beta$-Glu-U) per $\mathrm{kg}$ of feed, were applied to the NC diet. The ME value utilized for the PC diet formulation was based on Agristat recommendations [33] and digestible amino acid values were based on recommendations by Tillman and Dozier [34].

Feed Manufacture. All feed was manufactured at the West Virginia University pilot feed mill. The PC and NC basal diets were prepared with 10 minute mixing times. The NC basal diet was then split into four allotments and then mixed with AC1 to the target dose of 50,100, 200, or 
$400 \beta$-Glu-U/kg for an additional 10 minute mixing time in a vertical single-screw mixer [35]. All diets were fed as mash feed. Complete feed samples for each treatment were collected post-enzyme addition for proximate analysis and $\beta$-glucanase activity as previously described.

Live Performance. Seven hundred twenty, 1-day-old Hubbard $\times$ Cobb 500 [36] straightrun chicks were obtained from a commercial hatchery [37]. On d 1, the chicks were weighed and allocated to 72 raised wire cages based on weight to create uniform initial pen weights. Raised wire cages were located in two identical cross-ventilated, negative-pressure rooms. The temperature for both rooms was set at $32{ }^{\circ} \mathrm{C}$ on $\mathrm{d} 1$ and decreased $3{ }^{\circ} \mathrm{C}$ per week. Feed and water were provided for ad libitum consumption. The experimental unit consisted of one pen of 10 broilers. Treatments were arranged in a randomized complete block design with the location of the cage in the room determining the block. Each block included 6 cages with a total of 12 blocks utilized. Variables measured included feed intake (FI), live weight gain (LWG), mortality corrected feed conversion ratio (FCR), and digesta viscosity.

Digesta Viscosity Measurements. On d 14 and d 21, 3 birds from each pen were euthanized via cervical dislocation. The entire digestive tract was then removed and digesta was squeezed out by hand into a $50 \mathrm{~mL}$ centrifuge tube [38]. Digesta was centrifuged [39] at 12,700 $\times \mathrm{g}$ for $5 \mathrm{~min}$ at $4{ }^{\circ} \mathrm{C}$. Using a pipette, $1 \mathrm{~mL}$ of supernatant was transferred into a micro centrifuge tube. Micro centrifuge tubes were placed into a $25{ }^{\circ} \mathrm{C}$ water bath [40] for approximately $10 \mathrm{~min}$. A total 0.5 $\mathrm{mL}$ of supernatant was then placed into a Brookfield cone and plate viscometer [41] utilizing a CPE-40 cone and CPE-44Y cup. Viscosity measurements were taken at $30 \mathrm{~s}$ and $1 \mathrm{~min}$ at two speeds of $10 \times \mathrm{g}$ and $20 \times \mathrm{g}$. The digesta viscosity methodology used was similar to methods utilized by Lamp and coauthors [42]. All animals were reared according to protocols approved by West Virginia University Animal Care and Use Committee. 


\section{Statistical Analysis}

All data were analyzed in a randomized complete block design with the raised wire cage location within room determining the block. The experimental unit was one pen containing 10 Hubbard $\times$ Cobb 500 broiler chicks. The PROC GLM procedure of SAS [43] was used to analyze data by one-way ANOVA. Means were then further separated using Fisher's least significant difference (LSD) post hoc comparison when the ANOVA was significant $(P \leq 0.05)$.

\section{RESULTS AND DISCUSSION}

\section{Preliminary Experiments}

The results of AC1 enzyme activity measurements of the 10 samples of mixed feed are presented in Table 2. The average enzyme activity from all samples was $425 \beta$-Glu-U/kg with a coefficient of variation (CV) of approximately 6\%, indicating that ground $\mathrm{AC} 1$ corn grain meal was homogenously mixed in feed preparations.

The average AC1 enzyme activity measured in the mash diet prior to pelleting and in the

pelleted feed samples is presented in Table 3. The results demonstrated that AC1 retains nearly $100 \%$ activity at 80 and $85^{\circ} \mathrm{C}$ conditioning and pelleting; and retains $90 \%$ activity after conditioning and pelleting at $90^{\circ} \mathrm{C}$. The thermostability of the grain-expressed AC1 glucanase allows it to survive the heat generated during typical industry feed pelleting conditions.

\section{Broiler Experiment}

Broiler performance metrics are exhibited in Table 4. Feed Intake was similar across all treatments throughout the study $(P>0.05)$. Between d1-14, birds fed PC had an improved LWG compared to that of the NC fed birds $(P<0.05)$. A similar trend was also observed for d1-14 FCR 
$(P=0.0728)$, with PC being numerically lower than NC. No statistical differences were observed in $\mathrm{d} 15-21(P=0.0674)$ and overall $(\mathrm{d} 1-21 ; P=0.084)$ LWG, but birds fed the PC diet tended to have the highest LWG. Overall (d1-21) FCR was significantly improved in PC vs. NC fed birds $(P<0.01)$. Birds fed $400 \beta-\mathrm{Glu}-\mathrm{U} / \mathrm{kg}$ had an intermediate performance improvement, as d1-14 LWG or d1-21 FCR was similar to both PC and NC $(P>0.05)$. Throughout the duration of the study, pen mortality for a single treatment did not exceed 2.5\% (data not shown).

Digesta viscosity data collected on d14 and d21 is displayed in Table 5. On d14, birds fed the corn/soybean diet (PC) had lower digesta viscosity (at either viscometer speed and time) than the NC group $(P<0.05)$, indicating that the addition of $10 \%$ wheat and $10 \%$ DDGS in the NC diet sufficiently increased digesta viscosity. To demonstrate the impact of exogenous feed enzymes on digesta viscosity in gastrointestinal tract, proper diet formulation is critical and can be challenging. For example, Gonzólez-Ortiz et al. (44) reported no effect of a wheat based diet on performance or jejunal digesta viscosity despite an $18 \% \mathrm{CV}$ in $\beta$-glucan content among the eight varieties of wheat tested in the feeding study. Loar et al. [45] included 8\% DDGS in broiler diets during the starter phase (0-14 d) and either $0,7.5,15,22.5$ or $30 \%$ DDGS in the grower phase diets (14-28 d), but only measured marginal changes $(\mathrm{P}=0.07)$ in intestinal viscosity among treatments in the grower phase. Prolonged feeding of high levels of DDGS $(0,7,14,21$ and 28\%) through the finisher phase ( 28 to $42 \mathrm{~d}$ ) did not increase digesta viscosity [46]. In the current study, inclusion of $10 \%$ wheat and $10 \%$ DDGS in corn/soybean diet had increased dietary NSP content and digesta viscosity demonstrating a good model to test exogenous carbohydrase enzymes such as AC1. When AC1 was added (200 and $400 \beta$-Glu-U/kg) to the NC diet, intestinal viscosity decreased to that of the PC fed birds $(P<0.05)$ indicating AC1 is effective in lowering viscosity at a dose of $200 \beta$-Glu-U/kg and higher during early bird development. When measured on $\mathrm{d} 21$, digesta 
viscosity values did not exhibit significant differences among treatments $(P>0.05)$. Past research has indicated that $\beta$-glucan and $\beta$-glucanase affect digesta viscosity more in younger birds compared to more mature birds [15]. Brenes et al. [19] has also found that exogenous NSP enzymes were most effective in the first weeks of life, with little or no effect observed for adult birds.

Lowering ileal viscosity is a demonstrated mode of action for $\beta$-glucanase [14, 15, 47], however, many factors including cereal type, structure, substrate concentrations, NSP solubility, and bird age can have a significant impact on intestinal viscosity as well as the response of NSP enzymes within the bird $[15,47,48]$.

In the current study, 200 and $400 \beta-$ Glu-U/kg inclusion from AC1 decreased intestinal viscosity. Birds fed $\mathrm{AC} 1$ at the $400 \beta$-Glu-U/kg dose had similar $14 \mathrm{~d}$ LWG and overall FCR as birds fed PC diet. Together, these data indicate AC1 had a positive effect on early broiler growth and feed conversion ratio that may have resulted from better access to dietary nutrients due to reduced intestinal viscosity.

\section{CONCLUSIONS AND APPLICATIONS}

1. The AC1 provided at $400 \beta-$ Glu-U/kg to a high NSP diet enabled equivalent $\mathrm{d} 14$ broiler digesta viscosity, weight gain and 1 to $21 \mathrm{~d}$ FCR compared to a low NSP control diet formulated with $100 \mathrm{kcal} / \mathrm{kg}$ higher ME.

2. Higher NSP ingredients may have a greater impact on digesta viscosity during early broiler growth (d1-14). 


\section{REFERENCES AND NOTES}

1. Min, Y.N., F. Yan, F.Z. Liu, C. Coto, and P.W. Waldroup. 2009. Effect of various dietary enzymes on energy digestibility of diets high in distillers dried grains with solubles for broilers. J. Appl. Poult. Res. 18:734-740.

2. Annison, G., and M. Choct. 1991. Anti-nutritive activities of cereal non-starch polysaccharides in broiler diets and strategies minimizing their effects. World's Poult. Science J. 47:232-242.

3. Choct, M. and G. Annison. 1992. Anti-nutritive effect of wheat pentosans in broiler chickens: roles of viscosity and gut microflora. British Poultry Science. 33:821-834.

4. Choct, M. 1997. Feed non-starch polysaccharides: chemical structures and nutritional significance. Feed Milling International. 13-26.

5. Henry, R.J. 1987. Pentosan and $(1 \rightarrow 3),(1 \rightarrow 4)-\beta$-Glucan concentrations in endosperm and wholegrain of wheat, barley, oats, and rye. J. of Cereal Science. 6:253-258.

6. Khattak, F.M., T.N. Pasha, Z. Hayat, and A. Mahmud. 2006. Enzymes in Poultry Nutrition. J. Animal. Pl. Sci. 16:1-2.

7. Ravindran, V. 2013. Feed enzymes: The science, practice, and metabolic realities. J. Appl. Poult. Res. 22:628-636.

8. Bedford, M. R. 2000. Exogenous enzymes in monogastric nutrition-their current value and future benefits. Anim. Feed Sci. and Tech. 86:1-13.

9. Bedford M.R. \& Partridge G.G (2010) Enzymes in farm animal nutrition, $2^{\text {nd }}$ Edition

10. Steenfeldt, S., A. Mullertz, J. F. Jensen. 1998. Enzyme supplementation of wheat-based diets for broilers: 1. Effect on growth performance and intestinal viscosity. Anim. Feed Sci. and Tech. 75 (1): 27-43.

11. Coppedge, J.R., L.A. Oden, B. Ratliff, B. Brown, F. Ruch, and J.T. Lee. 2012. Evaluation of nonstarch polysaccharide-degrading enzymes in broiler diets varying in nutrient and energy levels as measured by broiler performance and processing needs. J. Appl. Poult. Res. 21:226-234.

12. Klein, J., M. Williams, B. Brown, S. Rao, and J. T. Lee. 2015. Effects of dietary inclusion of a cocktail NSPase $\beta$-mannanase separately and in combination in low energy diets on broiler performance and processing parameters. J. Appl. Poult. Res. 24:489-501.

13. Von Wettstein D., Mikhaylenko G., Froseth J.A. \& Kannangara C.G (2000) Improved barley broilder feed with transgenic malt containing heat-stable (1,3-1,4)- $\beta$-glucanase. PNAS, 97(25):13512-7

14. Almirall, M. and Esteve-Garcia, E. (1994) Rate of passage of barley diets with chromium oxide: influence of age and poultry strain and effect of $\beta$-glucanase supplementation. Poultry Science 73, 1433-1440.

15. Almirall, M., Francesch, M., Perez-Vendrell, A.M., Brufau, J. and Esteve-Garcia, E. (1995) The differences in intestinal viscosity produced by barley and $\beta$-glucanase alter digesta enzyme activities and ileal nutrient digestibilities more in broiler chicks than in cocks. Journal of Nutrition 125, 947-955.

16. Von Wettstein D., Warner J. \& Kannangara C.G. (2003) Supplements of transgenic malt or grain containing (1,3-1,4)-beta-glucanase increase the nutritive 
value of barley-based broiler diets to that of maize. British Poultry Science, 44(3):43849.

17. Józefiak D., Rutkowski A., Jensen B.B. \& Engberg R.M. (2006) The effect of $\beta$ glucanase supplementation of barley- and oat-based diets on growth performance and fermentation in broiler chicken gastrointestinal tract. British Poultry Science, 47 (1): 57-64

18. Smulikowska, S. (1998) Relationship between the stage of digestive tract development in chicks and the effect of viscosity reducing enzymes on fat digestion. Journal of Animal and Feed Sciences 7, 125-134.

19. Brenes A., Guenter W., Marquardt R.R., Rotter B.A., 1993. Effect of $\beta$ glucanase/pentosanase enzyme supplementation on the performance of chickens and laying hens fed wheat, barley, naked oats and rye diets. Can. J. Anim. Sci. 73, 941-951

20. Pen, J., T. C. Verwoerd, P. A. van Paridon, R. F. Beudeker, P. J. M. van den Elzen, K. Geerse, J. D. van der Klis, H. A. J. Versteegh, A. J. J. van Ooyen, and A. Hoekema. 1993. Phytase-containing transgenic seeds as a novel feed additive for improved phosphorus utilization. Nat. Biotechnol. 11:811-814.

21. Nyannor, E. K. D. and O. Adeola. 2008. Corn Expressing an Escherichia Coli-Derived Phytase Gene: Comparative Evaluation Study in Broiler Chicks. Poult. Sci. 87: 20152022.

22. Nyannor, E. K. D., M. R. Bedford, and O. Adeola. 2009. Corn expressing an Escherichia coli-derived phytase gene: Residual phytase activity and microstructure of digesta in broiler chicks. Poult. Sci. 88: 1413-1420.

23. Gao, C. Q., Q. G. Ma, C. Ji, X. G. Luo, H. F. Tang, and Y. M. Wei. 2012. Evaluation of the compositional and nutritional values of phytase transgenic corn to conventional corn in roosters. Poult. Sci. 91: 1142-1148.

24. Gao, C. Q., C. Ji, L. H. Zhao, J. Y. Zhang, and Q. G. Ma. 2013. Phytase transgenic corn in nutrition of laying hens: Residual phytase activity and phytate phosphorus content in the gastrointestinal tract. Poult. Sci. 92: 2923-2929.

25. Denbow, D. M., E. A. Grabau, G. H. Lacy, E. T. Kornegay, D. R. Russell, and P. F. Umbeck. 1998. Soybeans Transformed with a Fungal Phytase Gene Improve Phosphorus Availability for Broilers. Poult. Sci. 79: 878-881.

26. Negrotto, D., M. Jolley, S. R. W. A. Beer, A. R. Wenck, and G. Hansen. 2000. The use of phosphomannose-isomerase as a selectable marker to recover transgenic maize plants (Zea mays L.) via Agrobacterium transformation. Plant cell reports, 19(8): 798803

27. Innova 43, New Brunswick, Matawan, NJ, ,

28. Spectrafuge 24D, Labnet International, Inc. Global

29. AZCL- $\beta$-glucan, Cat\# T-BGZ-1000T, Megazyme, Wicklow, Ireland

30. Assay of endo- $\beta$-glucanases using beta-glucazyme tablets. https://secure.megazyme.com/files/Booklet/T-BGZ_DATA.pdf

31. 96-well block, Corning, Inc., Bedford, MA

32. Microplate, Corning, Inc., Bedford, MA

33. Agri Stats Inc., Fort Wayne, IN, 46825.

34. Tillman, P. B. and W.A. Dozier. 2013. Current Amino Acid Considerations for Broilers: Requirements, Ratios, Economics 
35. Vertical mixer, Avery Weigh-Tronix, Fairmont, MN.

36. Cobb-Vantress, Siloam Springs, AR.

37. Pilgrim's Pride, Moorefield, WV.

38. Fisher Scientific, Fairlawn, NJ.

39. Sorvall Evolution RC Centrifuge, Asheville, NC.

40. TC-605 Refrigerated Bath, Brookfield Engineering Laboratories Inc., Middleboro, MA.

41. Brookfield LVDV-II+Pro Viscometer, Brookfield Engineering Laboratories Inc., Middleboro, MA.

42. Lamp, A. E., A. M. Evans, J. S. Moritz. 2015. The effects of pelleting and glucanase supplementation in hulled barley based diets on feed manufacture, broiler performance, and digesta viscosity. J. Appl. Poult. Res. 24:295-303.

43. SAS Institute. 2017. The SAS System for Windows 2017. Release 9.4. SAS Inst. Inc., Cary, NC.

44. Gonzólez-Ortiz G., Olukosi O., Bedford M.R. 2016 Evaluation of the effect of different wheats and xylanase supplementation on performance, nutrient and energy utilization in broiler chicks. Animal Nutrition, 2: 173-179

45. Loar, R. E., II, J. S. Moritz, J. R. Donaldson, and A. Corzo. 2010. Effects of feeding distillers dried grains with solubles to broilers from 0 to 28 days posthatch on broiler performance, feed manufacturing efficiency and selected intestinal characteristics. Poult. Sci. 89:2242-2250

46. Loar II R.E., Donaldson J.R., and Corzo A. (2012) Effects of feeding distillers dried grains with solubles to broilers from 0 to 42 days posthatch on broiler performance, carcass characteristics, and selected intestinal characteristics. The Journal of Applied Poultry Research, Volume 21, Issue 1, Pages 48-62

47. Bedford, M. R., and H. L. Classen. 1992. Reduction of intestinal viscosity in barleyfed broilers by $\beta$-glucanase: Site of action and effect on bird performance. Proceedings of the British Society of Animal Production. 54:86-88.

48. Palander S., Näsi M., Järvinen S. (2005) Effect of age of growing turkeys on digesta viscosity and nutrient digestibility of maize, wheat, barley and oats fed as such or with enzyme supplementation. Arch Animal Nutrition, 59(3): 191-203 
Table 1. Ingredient composition of experimental diets from 1 to $21 \mathrm{~d}$

\begin{tabular}{|c|c|c|}
\hline \multirow[b]{2}{*}{ Ingredients } & \multicolumn{2}{|c|}{ Inclusion (\%) } \\
\hline & Positive Control $^{1}$ & Negative Control \\
\hline Corn & 59.92 & 48.36 \\
\hline Soybean Meal & 32.47 & 25.84 \\
\hline Wheat & -- & 10 \\
\hline DDGS & -- & 10 \\
\hline Dicalcium Phosphate & 1.82 & 1.74 \\
\hline Limestone & 1.35 & 1.38 \\
\hline L-Lysine & 0.29 & 0.43 \\
\hline DL-Methionine & 0.35 & 0.34 \\
\hline Soybean Oil & 2.93 & 1.11 \\
\hline Vit/Min Premix & 0.25 & 0.25 \\
\hline L-Threonine & 0.19 & 0.23 \\
\hline White Salt & 0.33 & 0.21 \\
\hline Sodium Bicarbonate & 0.10 & 0.10 \\
\hline \multicolumn{3}{|c|}{ Calculated Nutrients $^{2}$} \\
\hline $\mathrm{ME}(\mathrm{kcal} / \mathrm{kg})$ & 3,000 & 2,900 \\
\hline Crude Protein (\%) & 20.00 & 20.00 \\
\hline Calcium (\%) & 1.01 & 1.01 \\
\hline Available Phosphorus (\%) & 0.46 & 0.46 \\
\hline Dig Methionine (\%) & 0.63 & 0.62 \\
\hline Dig Lysine $(\%)$ & 1.20 & 1.20 \\
\hline Dig Methionine and Cysteine (\%) & 0.90 & 0.90 \\
\hline \multicolumn{3}{|c|}{ Analyzed Nutrients } \\
\hline Crude Protein (\%) & 20.10 & 19.80 \\
\hline Crude Fat $(\%)$ & 5.55 & 4.20 \\
\hline
\end{tabular}

${ }^{1}$ The positive control diet contained $100 \mathrm{kcal} / \mathrm{kg}$ ME more than the negative control diets.

${ }^{2}$ Metabolizable Energy and Available Phosphorus were based on Agristat values as suggested by M. Donohue. 2013. The Challenges in Feeding Broilers in Times of High and Volatile Feed Ingredient Costs: How to Cover the Costs? 2013 Mid-Atlantic Nutrition Conference proceedings. Digestible amino acids were based on the digestible lysine value (1.2\%) suggested by P. B. Tillman and W.A. Dozier. 2013. Current Amino Acid Considerations for Broilers: Requirements, Ratios, Economics. www.thepoultryfederation.com for $8-14$ day broilers. Digestible amino acid to digestible lysine ratios followed further recommendations of this communication (minimum of 0.54 methionine, 1.02 TSAA, 0.90 threonine, 0.21 tryptophan). 
Table 2. $\mathrm{AC} 1^{1} \beta$-glucanase activity in 10 mash diet samples to determine homogeneity.

\begin{tabular}{|c|c|}
\hline Mash Diet Sample & $\begin{array}{c}\beta-\text { Glucanase } \\
\text { U/kg }\end{array}$ \\
\hline 1 & 411.95 \\
\hline 2 & 394.10 \\
\hline 3 & 471.05 \\
\hline 4 & 401.30 \\
\hline 5 & 433.70 \\
\hline 6 & 428.15 \\
\hline 7 & 448.85 \\
\hline 8 & 392.00 \\
\hline 9 & 451.85 \\
\hline 10 & 420.20 \\
\hline Average & 425.32 \\
\hline Standard Deviation & 26.44 \\
\hline
\end{tabular}

${ }^{1} \mathrm{AC} 1$ product was mixed with feed for a target dose of $500 \beta$-glucanase U/kg feed.

${ }^{2} \beta$-glucanase activity was an average of duplicate tests on each protein extract from each feed sample. 
Table 3. AC1 $\beta$-glucanase activity in feed before (mash) and after pelleting at different temperatures.

\begin{tabular}{|c|c|c|c|}
\hline $\begin{array}{c}\text { Sample / } \\
\text { Conditioner } \\
\text { Temperature }\end{array}$ & $\begin{array}{c}\text { Activity }^{1} \\
(\beta \text {-glucanase U/kg) }\end{array}$ & $\begin{array}{c}\text { Standard } \\
\text { Deviation }\end{array}$ & $\begin{array}{c}\text { Recovery } \\
(\%)\end{array}$ \\
\hline Mash $^{3}$ & 500.45 & 50.68 & - \\
\hline $80^{\circ} \mathrm{C}$ Pellet & 551.56 & 45.31 & 110.21 \\
\hline $85^{\circ} \mathrm{C}$ Pellet & 496.68 & 38.99 & 99.25 \\
\hline $90^{\circ} \mathrm{C}$ Pellet & 451.58 & 30.70 & 90.23 \\
\hline
\end{tabular}

${ }^{1} \beta$-glucanase activity was tested from duplicate protein extracts from each feed sample.

${ }^{2}$ Calculated as a percentage of the analyzed $\beta$-glucanase activity within the mash diet.

${ }^{3} \mathrm{AC} 1$ product was mixed with feed for a target dose of $500 \beta$-glucanase $\mathrm{U} / \mathrm{kg}$ feed. 
Table 4. Growth performance of Hubbard x Cobb 500 straight-run broilers fed a corn, soybean meal, wheat, and DDGS diet with various $\mathrm{AC} 1$ concentrations

\begin{tabular}{|c|c|c|c|c|c|c|c|c|c|c|}
\hline \multirow[t]{2}{*}{ Diet Formulation } & \multirow{2}{*}{$\begin{array}{c}\text { Analyzed } \\
\beta \text {-glucanase } \\
(\beta-\text {-Glu-U/kg) }\end{array}$} & \multicolumn{3}{|c|}{1 to $14 \mathrm{~d}$} & \multicolumn{3}{|c|}{14 to $21 \mathrm{~d}$} & \multicolumn{3}{|c|}{1 to $21 \mathrm{~d}$} \\
\hline & & $\begin{array}{c}\text { Bird FI }{ }^{1} \\
\quad(\mathrm{~kg})\end{array}$ & $\begin{array}{l}\text { Bird LWG } \\
\quad(\mathrm{kg})\end{array}$ & $\begin{array}{c}\mathrm{FCR}^{3} \\
(\mathrm{~kg} / \mathrm{kg})\end{array}$ & $\begin{array}{l}\text { Bird FI } \\
\quad(\mathrm{kg})\end{array}$ & $\begin{array}{l}\text { Bird LWG } \\
\quad(\mathrm{kg})\end{array}$ & $\begin{array}{c}\text { FCR } \\
(\mathrm{kg} / \mathrm{kg})\end{array}$ & $\begin{array}{c}\text { Bird FI } \\
\quad(\mathrm{kg})\end{array}$ & $\begin{array}{l}\text { Bird LWG } \\
\quad(\mathrm{kg})\end{array}$ & $\begin{array}{c}\text { FCR } \\
(\mathrm{kg} / \mathrm{kg})\end{array}$ \\
\hline Negative Control (NC) & --- & 0.418 & $0.293^{\mathrm{b}}$ & 1.42 & 0.640 & 0.413 & 1.55 & 1.06 & 0.718 & $1.48^{\mathrm{a}}$ \\
\hline $\mathrm{NC}+50 \beta-\mathrm{Glu}-\mathrm{U} / \mathrm{kg}$ & $46.1 \pm 13.5$ & 0.423 & $0.298^{\mathrm{b}}$ & 1.40 & 0.624 & 0.397 & 1.58 & 1.05 & 0.699 & $1.48^{\mathrm{a}}$ \\
\hline $\mathrm{NC}+100 \beta-G l u-U / k g$ & $88.6 \pm 22.5$ & 0.424 & $0.297^{\mathrm{b}}$ & 1.43 & 0.650 & 0.409 & 1.60 & 1.07 & 0.715 & $1.50^{\mathrm{a}}$ \\
\hline $\mathrm{NC}+200 \beta-$ Glu-U/kg & $237.5 \pm 54.7$ & 0.419 & $0.294^{\mathrm{b}}$ & 1.42 & 0.650 & 0.411 & 1.59 & 1.07 & 0.707 & $1.49^{\mathrm{a}}$ \\
\hline $\mathrm{NC}+400 \beta-$ Glu-U/kg & $418.8 \pm 19.4$ & 0.417 & $0.301^{\mathrm{ab}}$ & 1.38 & 0.629 & 0.408 & 1.55 & 1.05 & 0.712 & $1.46^{\mathrm{ab}}$ \\
\hline Positive Control $^{4}$ & --- & 0.420 & $0.314^{\mathrm{a}}$ & 1.33 & 0.655 & 0.434 & 1.52 & 1.08 & 0.750 & $1.42^{\mathrm{b}}$ \\
\hline \multicolumn{2}{|c|}{ Treatment P-value } & 0.9924 & 0.0330 & 0.0728 & 0.2004 & 0.0674 & 0.3302 & 0.4862 & 0.0840 & 0.0098 \\
\hline \multicolumn{2}{|c|}{ Treatment SEM } & 0.0083 & 0.0046 & 0.0239 & 0.0100 & 0.0082 & 0.0271 & 0.0134 & 0.0122 & 0.0170 \\
\hline \multicolumn{2}{|c|}{ Fisher's LSD ${ }^{5}$} & --- & 0.013 & --- & --- & 0.0233 & --- & --- & 0.0345 & 0.0481 \\
\hline
\end{tabular}

${ }^{1} \mathrm{FI}=$ Feed Intake

${ }^{2} \mathrm{LWG}=$ Live Weight Gain

${ }^{3}$ Feed Conversion Ratio (Feed:Gain) was calculated using mortality weight.

${ }^{4}$ The positive control diet was corn and soybean meal based and contained $100 \mathrm{kcal} / \mathrm{kg}$ calculated ME more than the negative control diets.

${ }^{5}$ Fisher's least significant difference multiple comparison test $(\mathrm{a}, \mathrm{b}, \mathrm{c})$

${ }^{\mathrm{a}-\mathrm{b}}$ Means, within a column, with superscripts without a common letter differ significantly $(\mathrm{P}<0.05)$ 
Table 5. Digesta viscosity of Hubbard x Cobb 500 straight-run broilers fed a corn, SBM, wheat, and DDGS diet with various AC1 concentrations

\begin{tabular}{|c|c|c|c|c|c|c|c|c|c|}
\hline \multirow[t]{3}{*}{ Diet Formulation } & \multirow{3}{*}{$\begin{array}{c}\text { Analyzed } \\
\beta \text {-glucanase } \\
(\beta-\text { Glu-U/kg) }\end{array}$} & \multicolumn{4}{|c|}{ D14 Digesta Viscosity (cP) } & \multicolumn{4}{|c|}{ D21 Digesta Viscosity (cP) } \\
\hline & & \multicolumn{2}{|c|}{$10 \mathrm{Xg}$} & \multicolumn{2}{|c|}{$20 \mathrm{Xg}$} & \multicolumn{2}{|c|}{$10 \mathrm{Xg}$} & \multicolumn{2}{|c|}{$20 \mathrm{Xg}$} \\
\hline & & $30 \mathrm{sec}$ & $1 \mathrm{~min}$ & $30 \mathrm{sec}$ & $1 \mathrm{~min}$ & $30 \mathrm{sec}$ & $1 \mathrm{~min}$ & $30 \mathrm{sec}$ & $1 \mathrm{~min}$ \\
\hline Negative Control & --- & $3.56^{\mathrm{ab}}$ & $3.55^{\mathrm{ab}}$ & $2.99^{\mathrm{ab}}$ & $3.01^{\mathrm{ab}}$ & 5.01 & 4.59 & 3.26 & 3.27 \\
\hline $\mathrm{NC}+50 \beta-\mathrm{Glu}-\mathrm{U} / \mathrm{kg}$ & $46.1 \pm 13.5$ & $3.67^{\mathrm{ab}}$ & $3.36^{\mathrm{ab}}$ & $2.80^{\mathrm{abc}}$ & $2.85^{\mathrm{abc}}$ & 4.44 & 4.55 & 3.28 & 3.27 \\
\hline $\mathrm{NC}+100 \beta-\mathrm{Glu}-\mathrm{U} / \mathrm{kg}$ & $88.6 \pm 22.5$ & $4.00^{\mathrm{a}}$ & $3.78^{\mathrm{a}}$ & $3.10^{\mathrm{a}}$ & $3.13^{\mathrm{a}}$ & 4.59 & 4.25 & 3.17 & 3.20 \\
\hline $\mathrm{NC}+200 \beta-\mathrm{Glu}-\mathrm{U} / \mathrm{kg}$ & $237.5 \pm 54.7$ & $3.48^{\mathrm{b}}$ & $3.23^{\mathrm{bc}}$ & $2.68^{\mathrm{bc}}$ & $2.76^{\mathrm{bc}}$ & 3.57 & 3.51 & 2.85 & 2.90 \\
\hline $\mathrm{NC}+400 \beta-\mathrm{Glu}-\mathrm{U} / \mathrm{kg}$ & $418.8 \pm 19.4$ & $3.43^{\mathrm{b}}$ & $3.20^{\mathrm{bc}}$ & $2.71^{\mathrm{bc}}$ & $2.79^{\mathrm{bc}}$ & 4.60 & 4.29 & 3.23 & 3.28 \\
\hline Positive Control ${ }^{1}$ & --- & $2.94^{\mathrm{c}}$ & $2.86^{\mathrm{c}}$ & $2.55^{\mathrm{c}}$ & $2.60^{c}$ & 4.22 & 3.95 & 2.85 & 2.85 \\
\hline \multicolumn{2}{|c|}{ Treatment P-value } & 0.0017 & 0.0056 & 0.0127 & 0.0157 & 0.1468 & 0.3334 & 0.4344 & 0.3870 \\
\hline \multicolumn{2}{|c|}{ Treatment SEM } & 0.163 & 0.163 & 0.113 & 0.108 & 0.3684 & 0.3743 & 0.2046 & 0.1927 \\
\hline \multicolumn{2}{|c|}{ Fisher's LSD ${ }^{2}$} & 0.461 & 0.463 & 0.321 & 0.306 & --- & --- & --- & --- \\
\hline
\end{tabular}

${ }^{1}$ The positive control diet was corn and soybean meal based and contained $100 \mathrm{kcal} / \mathrm{kg}$ calculated ME more than the negative control diets.

${ }^{2}$ Fisher's least significant difference multiple comparison test (a, b, c)

${ }^{\mathrm{a}-\mathrm{c}}$ Means, within a column, with superscripts without a common letter differ significantly $(\mathrm{P}<0.05$ 


\section{CIRRICULUM VITAE}

\section{Victoria E. Ayres}

\section{EDUCATION}

Degree Obtained: Bachelor of Science in Agriculture, Animal Sciences; May 2017

University Attended: The Ohio State University

Undergraduate GPA: 3.2

Expected Degree: Master of Science, Animal and Food Science

Expected Graduation Date: May 2019

University Attended: West Virginia University

Current GPA: 3.43

\section{EDUCATION HONORS/AWARDS}

\section{Scholarships/Grants Received}

- Jones Hamilton Company Undergraduate Student Travel Award: July 2017

- Midwest Poultry Consortium's Center of Excellence: May 2017- August 2017

- Federal Pell Grant: 2016

- President's Affordability Grant: 2016

- Research Scholar Award: June 2016

- Robert L. Hocker Poultry Science Scholarship Fund: June 2016

- Scarlet and Gray Grant: 2016

- Ted Berry Scholarship: June 2013, 2015, 2016

\section{Awards and Honors}

- Graduation with Research Distinction: Spring 2017

- College of Food, Agricultural, and Environmental Sciences Dean's List: Spring 2016 


\title{
PUBLICATIONS
}

\section{First Author Publications}

V.E. Ayres, J.N. Broomhead, X. Li, R.M. Raab, and J.S. Moritz. 2019. Viscosity and growth response of broilers fed high fiber diets supplemented with a corn-produced recombinant carbohydrase. Submitted to Journal of Applied Poultry Research February 28, 2019.

V.E. Ayres, H. Baldwin, X. Li, H. Xu, M. Raab, J. Boney, J. Broomhead, and J.S. Moritz. 2018. Corn-expressed carbohydrase can improve performance and reduce digesta viscosity of broilers fed a high non-starch polysaccharide diet. Journal of Applied Poultry Research. 27(4): 499-506.

\begin{abstract}
s
V.E. Ayres, S.A. Loop, and J.S. Moritz. 2019. Exogenous enzyme supplementation can overcome amino acid deficiency in broiler starter diets. Submitted to Poult. Sci. April 3, 2019.

K. Harding, A.E. Lamp, T. Boltz, V.E. Ayres, and J.S. Moritz. 2019. The effect of pelleting diets composed of large particle corn using standard conditioning and more thermally aggressive conditioning utilizing a hygienizer. Submitted to Poult. Sci. April 3, 2019.

V.E. Ayres, H. Baldwin, X. Li, H. Xu, M. Raab, J. Boney, J. Broomhead, and J.S. Moritz. 2018. Corn-expressed carbohydrase can improve performance and reduce digesta viscosity of broilers fed a high non-starch polysaccharide diet. Poult. Sci. (Accepted Abstract (132)).

V.E. Polentz, J. Griffin, S. Hutsko, M.W. Wick, and M. Cressman. 2017. The effects of diet and age on breast muscle characteristics in commercial broilers. Poult. Sci. (Accepted Abstract (74)).

\section{Co-author Publications}

H.Z. Castada, V. Polentz, S. Barringer, and M. Wick. 2017. Temperature- dependent Henry's Law constants of 4- alkyl branched- chain fatty acids and 3- methylindole in an oil- air matrix and analysis of volitiles in lab fat using selected ion flow tube mass spectrometry. Rapid Communications in Mass Spectrometry.
\end{abstract}

\section{RESEARCH EXPERIENCE}

\section{National Meeting Oral Presentations}

- 2018 Poultry Science Association Annual Meeting (San Antonio, TX) (Graduate Student)

$\circ$ "Corn- expressed carbohydrase can improve performance and reduce digesta viscosity of broilers fed a high non-starch polysaccharide diet."

- 2017 Poultry Science Association (Orlando, FL) (Undergraduate Student)

- "The effects of diet and age on breast muscle characteristics in commercial broilers."

\section{Graduate Teaching Assistant}

- Teaching Assistant for Poultry Judging at West Virginia University: Spring 2018 
- Assisted Dr. Joseph Moritz instructing classes and selected top students to compete in the National Collegiate Poultry Judging Contest.

\section{Graduate Research Assistant}

- Led a contract study with Huvepharma to determine digestible amino acid concentrations of diets that vary in amino acid concentration and enzyme inclusion: Spring 2019

- Led a contract study with Agrivida, Inc. analyzing a recombinant carbohydrase enzyme that was included at varying inclusions in high non- starch polysaccharide diets: Spring 2018

- Attended the Poultry Science Association's Annual Meeting: 2017, 2018

○ San Antonio, TX (2018)

- Orlando, FL (2017)

- Assisted with a traveling backyard poultry demonstration in various locations throughout the state of West Virginia: 2018- present.

- Assisted with numerous West Virginia University Animal Science Farm tours: 2018present.

- Assisted with the Poultry Festival: 2018

o Moorefiled, WV

- Assisted with conducting an annual poultry judging competition

- Assisted with the West Virginia State FFA Poultry CDE Competition: 2017, 2018

○ Created classes and organized the competitions

- Davis College Welcome Back BBQ: 2017, 2018

○ Assisted Dr. Joseph Moritz preparing and delivering food

\section{FIELD EXPERIENCE}

- Interned with Cargill Animal Nutrition as the Poultry Additive Intern in Brookville, OH. ○ 2017

- Conducted research investigating the effects of age and diet on the onset of woody breast and resulting breast meat quality characteristics with Dr. Cressman and Dr. Wick at The Ohio State University.

○ 2016, 2017

- Aided in the study of “Temperature- dependent Henry's Law constants of 4- alkyl branched- chain fatty acids and 3- methylindole in an oil- air matrix and analysis of volitiles in lab fat using selected ion flow tube mass spectrometry" at The Ohio State University.

○ 2016

- Assist graduate students with research investigating poultry muscle biology and immunology at The Ohio State University.

o 2015-2017 


\section{SKILLS}

- Efficient in Microsoft Word, Microsoft Excel, and SAS 9.4

- Feed Manufacture

- Diet Formulation

- California Pellet Mill operation

- Poultry processing

- Tibia extraction

- Ileum extraction

- Poultry vaccination experience

- Brookfield cone and plate viscometer

- Caecectomy surgery

- RNA isolation

- cDNA synthesis

- qRT-PCR

- Nanodrop

- Agarose gel electrophoresis

- Histology preparation including sample fixing, embedding, slicing, and staining with hematoxylin and eosin

- Meullenet-Owens Razor Shear Force Analysis

- $\quad$ Selected Ion Flow Tube Mass Spectroscopy (SIFT-MS) 
